\title{
Investor Attention, Market Dynamics, and Momentum in the Korean Stock Market
}

\author{
Cheoljun Eom, Professor, Pusan National University
}

Uk Chang, Associate Professor, Duksung Womens University

Byung Jin Kang, Professor, Soongsil University

Woo Baik Lee, Professor, Korea National Open University

Jong Won Park ${ }^{* *}$, Professor, University of Seoul

\begin{abstract}
$\langle$ Abstract $\rangle$
This study examines the effects of investor attention on momentum in the Korean stock market. The results reveal significant negative momentum profits in stock groups with high investor attention (high turnover stocks), but insignificant results in those with low investor attention (low turnover stocks). Within high turnover stock groups, the winner portfolio has a declining price trend and insignificant performance, while the loser portfolio realizes significant positive performance through a substantial price increase in the future period. The momentum effect is highly dependent on the reversed performance of the loser portfolio. Second, the performance of the large overreaction stock group shows a more significant negative momentum effect compared to the low overreaction stock group, that is, the degree of overreaction significantly affects the momentum effect. Third, negative momentum profits are consistently observed regardless of the market dynamics. Specifically, more substantial and significant negative performance occurs in the transition market, where the market situation reverses between the past and future periods. Fourth, negative momentum profits are consistently identified even after controlling for the impact of common factors and volatility and liquidity into turnover. Our findings are qualitatively different from the characteristics of the traditional momentum effects generally reported in Western countries.
\end{abstract}

Keywords: Investor Attention; Market Dynamics; Cross-Sectional Momentum; Residual Momentum; Overreaction

JEL Classification: G11, G12, G40

\footnotetext{
* This work was supported by the National Research Foundation of Korea Grant funded by the Korean Government (NRF-2018S1A5A2A03032761), and (C.Eom) a 2-Year Research Grant of Pusan National University

** Corresponding Author. Address: College of Business Administration, University of Seoul, Seoulsiripdaero 163, Dongdaemun-gu, Seoul 02504, Korea, Email: parkjw@uos.ac.kr; Tel: +82-2-6490-2234; Fax: +82-2-6490-2219.
}

Received: March 16, 2020; Revised: July 7, 2020; Accepted: July 13, 2020 


\title{
투자자관심과 시장상황이 한국주식시장의 모멘텀 효과에 미치는 영향*
}

\author{
엄 철 준 (부산대학교 교수) \\ 장 욱 (덕성여자대학교 부교수) \\ 강 병 진 (숭실대학교 교수) \\ 이 우 백 (한국방송통신대학교 교수) \\ 박 종 원 (서울시립대학교 교수)**
}

\begin{abstract}
본 연구는 우리 시장에서 투자자관심과 시장상황이 모멘텀 효과에 미치는 영향을 분석하였다. 분석결과, 투자자관심이 높은 주식집단(높은 회전율 집단)에서 유의한 음(-)의 모멘텀 이익이 확인되나, 투자자 관심이 낮은 주식집단(낮은 회전율 집단)에서는 유의한 결과를 얻을 수 없다. 높은 회전율 집단에서 패자포트폴리오는 미래기간에 큰 폭의 가격반전으로 유의한 양(+)의 성과를 실현한다. 둘째, 과잉반응 정도는 모멘텀 효과에 의미있는 영향을 미친다. 회전율이 높은 집단에서 과잉반응 정도가 높은 집단이 낮은 집단에 비해 보다 강한 음(-)의 모멘텀 이익을 보여준다. 셋째, 음(-)의 모멘텀 이익은 시장상황의 동적 특성에 관계없이 관찰되나, 시장상황이 반전하는 전환시장에서 보다 강한 음(-)의 모멘텀 이익을 보여준다. 넷째, 높은 회전율 집단에서 보이는 음(-)의 모멘텀 이익은 공통요인의 영향을 통제한 후에도 유의하게 나타나며, 개별주식의 변동성이나 유동성 특성과 관계없이 나타난다.
\end{abstract}

핵심 단어 : 투자자관심, 시장상황의 동적 특성, 횡단면 모멘텀, 잔차모멘텀, 과잉반응

JEL 분류기호: G11, G12, G40

\footnotetext{
* 본 연구는 한국연구재단의 지원을 받아 수행된 연구(NRF-2018S1A5A2A03032761)입니다. 그리고 첫 번째 저자(엄철준)에 대한 부산대학교 기본연구지원사업(2년)의 지원을 받아 수행된 연구입니다. ** 연락담당 저자. 주소: 서울특별시 동대문구 서울시립대로 163 서울시립대학교 경영대학, 02504 ; E-mail: parkjw@uos.ac.kr; Tel: 02-6490-2234; Fax: 02-6490-2219.
} 


\section{1. 서론}

주식시장에서 과거기간의 가격 정보를 활용한 투자전략은 학계와 실무계 모두에서 높은 관심을 받고 있는 주제이다. 특히, 과거 12 개월 이내의 투자성과 정보를 이용하여 미래기간에 양(+)의 성과를 얻을 수 있음을 보여주는 모멘텀 효과(momentum effect, Jegadeesh and Titman, 1993)의 존재가 널리 인정되고 있다. 모멘텀 효과는 전통적인 위험-수익 관계로는 설명하기 어려운 비정상적 현상들(anomalies) 중의 하나로 분류되지만, 행동재무학적인 관점에서는 Daniel et al.(1998)의 과잉신뢰가설(overconfidence hypothesis)이나 Hong and Stein(1999)의 점진적 정보확산가설(gradual information diffusion mechanism) 등으로 설명되며 이 때 투자자관심 (investor attention)은 모멘텀 효과를 가져오는 중요한 요인으로 분석되고 있다.1) 한편 투자자 관심은 시장상황의 변화에 유의하게 영향을 받는 것으로 알려져 있다. 여러 선행연구(Hong and Stein, 1999; Karlsson et al., 2009; Cooper et al., 2004; Asem and Tian, 2010)는 투자자관심이 주식시장의 상황에 영향을 받으며, 이에 따라 모멘텀 효과 역시 시장상황에 유의하게 영향을 받는다는 실증 증거를 보여준다. 아시아 주식시장에서의 모멘텀 효과를 조사한 Chui et al.(2000, 2010)은 대부분의 국가들(특히, 일본, 한국 등)에서 서구지역에서 널리 알려진 양(+)의 모멘텀 이익을 관찰하기 어려움을 보고한다. 한국 주식시장을 대상으로 모멘텀 효과를 실증한 Kho(1997), Chae and Eom(2009), Lee and Cho(2014) 등 역시 음(-)의 모멘텀 이익을 보고한다.2) 본 연구는 한국 주식시장을 대상으로 서구시장에서 확인되는 전통적 모멘텀 효과와 달리 음(-)의 모멘텀 이익이 유의하게 나타나는지를 분석하고 투자자관심과 주식시장의 상황변화가 음 $(-)$ 의 모멘텀 이익에 미치는 영향을 구체적으로 살펴본다.

투자자관심은 여러 연구에서 모멘텀 효과에 영향을 미치는 주요 요인으로 보고되고 있다. Hou et al.(2009)는 투자자관심이 높은 주식들에서 과잉반응에 기반한 가격모멘텀(price momentum)이 발생하며, 투자자관심이 낮은 종목들에서 과소반응에 기반한 이익공시모멘텀(earnings momentum)이 발생한다는 실증결과를 보여준다. Daniel et al.(1998)은 투자자의 과신(overconfidence)과 자기귀속(self-attribution) 편의를 근거로 투자자의 과잉반응이 모멘텀 이익의 단기지속성(short-term continuation)과 장기반전(long-term reversal)을 가져온다는 이론적 근거를 제시한다. Hong and Stein(1999)은 투자자들(news watchers and momentum traders)이 사적 정보를 인식하는 시간차이(gradual information diffusion)로 인해 단기적인 가격지속성이 나타나고 과잉반응에 의해 장기반전이 나타남을 주장한다.

1) 인지심리학 분야의 여러 연구는 인간의 두뇌활동에서 관심이 유한한 자원임을 보여주며(Kahneman, 1973; Pashler and Johnston, 1998), 증권투자와 관련한 여러 연구는 투자자관심이 투자결정에 중요한 영향을 미치는 요인임을 잘 보여준다(Barber and Odean, 2008; Corwin and Coughenour, 2008; Hou et al., 2009).

2) Kim and Byun(2011)은 1980년 이후 한국 주식시장을 대상으로 과거기간 가격정보를 이용한 투자 전략을 분석한 연구들을 검토·정리한 결과 대부분의 연구가 유의한 양(+)의 모멘텀 이익을 지지하는 증거를 제시하지 못한다고 보고한다. 
Investor Attention, Market Dynamics, and Momentum in the Korean Stock Market

모멘텀 관련연구에서 투자자관심의 대용변수로 거래량 회전율(turnover)이 대표적으로 이용된다. 즉, 투자자가 관심을 갖지 않는 주식은 거래량이 낮지만, 투자자관심이 높은 주식들은 투자자 간의 이질적 기대에 따라 높은 거래량을 보인다는 것이다. Lee and Swaminathan (2000)은 거래량이 미래기간 투자성과와 과거기간 투자성과 간의 관계를 어떻게 연계시키는지에 대한 연구에서, 과거기간의 거래량이 가격모멘텀의 크기와 지속성을 예측하는데 유용하다는 것을 보고하고, 특히 모멘텀 효과의 단기 과소반응과 장기 과잉반응을 이해하는데 거래량이 중요한 지표임을 보여준다. Statman et al.(2006)은 투자자의 과신과 거래량 간의 관계 검증에서 투자자 과신의 수준과 거래량은 과거 수익률과 함께 변화한다는 것을 확인하였다. Hou et al.(2009)는 높은 거래량 회전율을 갖는 주식집단에서 과잉반응 가격 모멘텀(overreactiondriven price momentum)을 관찰하고, 낮은 거래량 회전율 주식집단에서 과소반응 이익공시 모멘텀(underreaction-driven earnings momentum)을 확인하였다.

한편, 투자자는 주식시장이 상승하는 상황에서 보다 많은 이익을 실현함에 따라 위험회피정도가 낮아지고 이로 인해 보다 강한 과신 편의를 가져 높은 모멘텀 이익이 발생하고, 주가가 하락하는 상황에서는 반대로 투자자들의 위험회피정도가 높아짐에 따라 약한 과신 편의와 낮은 모멘텀 이익이 발생한다는 것이 보고된다(Hong and Stein, 1999; Karlsson et al., 2009). Cooper et al.(2004)는 과거 상승시장에서 구성된 모멘텀 포트폴리오가 미래기간에 유의한 양(+)의 모멘텀 이익을 실현하지만, 과거 하락시장에서 구성된 모멘텀 포트폴리오는 미래기간에 모멘텀 효과를 지지하는 증거를 확인하기 어렵다고 보고한다. Asem and Tian(2010)은 과거기간과 미래기간의 시장상황을 함께 고려한 동적 시장상황(market dynamics)에서의 모멘텀 효과를 검증하고, Daniel et al.(1998)의 주장과 같이, 과거 시장상황이 미래 시장상황과 다른 방향으로 변화하는 전환시장(market transition) 보다는 동일한 방향으로 변화하는 지속시장(market continuation)에서 보다 유의한 양(+)의 모멘텀 이익이 실현된다고 보고한다. 한편 아시아지역 에서 모멘텀 이익에 대한 시장상황의 영향을 분석한 Hanauer(2014)는 일본, 한국, 대만의 주식시장에서 과거와 미래 시장상황의 특성이 지속성을 갖는 경우에 유의한 양(+)의 초과수익률과 위험조정수익률이 나타남을 보인다. 이는 Asem and Tian(2010)의 동적 시장상황 조건부 모멘텀 효과의 발견을 지지하는 증거이다. 음(-)의 모멘텀 이익이 보고된 대만 주식시장을 대상으로 시장상황을 고려한 연구들에서, Du et al.(2009)는 빈번한 시장하락과 전환시장이 음(-)의 모멘텀 이익을 발생시키는 주요 원인임을 주장한다. 이는 과거기간 시장상황이 모멘텀 효과에 미치는 영향을 보고한 Cooper et al.(2004)의 주장을 지지하는 증거이다. Lin et al.(2016)은 Asem and $\operatorname{Tian}(2010)$ 에 근거하여 동적 시장상황을 대만 주식시장에 고려할 때, 과거 상승시장과 동일한 방향의 미래 상승시장에서 유의한 양 $(+)$ 의 모멘텀 이익이 확인되지만, 과거 하락시장과 미래 하락시장의 경우에는 유의한 음(-)의 모멘텀 이익이 나타남을 보고한다. 즉, 지속시장에서 유의한 양(+)의 모멘텀 이익의 관찰은 과거 상승시장과 미래 상승시장의 조합에서 강하게 나타난다는 것이다.

본 연구는 선행연구에 근거하여 거래량 회전율 기반의 모멘텀 포트폴리오를 구성하고 모멘텀 효과를 분석한다. 이후 확인되는 모멘텀 이익의 원인을 투자자의 과잉반응 정도와 주식시장의 
한국증권학회지 제49권 4호 (2020)

동적 특성을 중심으로 검증한다. 본 연구와 기존연구의 차이를 주요 실증설계를 중심으로 설명하면 다음과 같다.

첫째, 본 연구에서는 투자자관심의 대용변수로 거래량 회전율을 기반으로 포트폴리오를 구성하고 모멘텀 효과 및 그 원인을 조사한다. Hameed and Kusnadi(2002)는 아시아 6개국(홍콩, 말레이시아, 싱가포르, 한국, 대만, 태국)의 주식시장에 대한 모멘텀 연구에서, 높은 거래량을 갖는 주식집단 내에서는 한국과 말레이시아에서 유의한 양(+)의 모멘텀 이익이 나타남을 보고한다. 이는 한국 주식시장에 대해 음(-)의 모멘텀 이익을 보고한 Chui et al.(2000)와 여러 국내연구의 결과와 대비되며 보다 세밀한 분석이 필요함을 의미한다. 본 연구에서는 $3 \times 5$ 거래량-모멘텀 포트폴리오를 구성한다. 거래량 회전율의 크기에 따라 상위 $30 \%$, 중간 $40 \%$, 하위 $30 \%$ 의 비율로 세 그룹으로 구분한다. 그리고 상위 $30 \%$ 의 높은 거래량 회전율을 갖는 주식집단과 하위 $30 \%$ 의 낮은 거래량 회전율을 갖는 주식집단을 중점 비교대상으로 선택한다. 거래량 회전율은 Lee and Swaminathan(2000), Statman et al.(2006), Hou et al.(2009) 등에서와 같이 모멘텀 포트폴리오를 구성하는 과거기간에서 월별 거래량을 발행주식수로 나눈 비율들의 평균값이다. 다음으로 각 거래량 회전율 주식집단 내에서 모멘텀 측정치를 기준으로 5 분위 포트폴리오(quintile portfolio)를 구성한다. 모멘텀 측정치는 과거기간에서의 보유기간수익률이다. 이때 단기반전효과(short-term reversal effect, Jegadeesh, 1990)의 영향을 통제하기 위하여 검증월의 직전 월은 제외한다. 거래량 주식집단 내에서 미래기간의 모멘텀 이익은 과거기간의 승자포트폴리오 $(\mathrm{W})$ 와 패자포트폴리오 $(\mathrm{L})$ 간의 투자성과 차이를 통해 확인한다. 즉, $\mathrm{W}-\mathrm{L}$ 무비용 포트폴리오(zero-cost portfolio)의 성과이다. W-L 무비용포트폴리오가 유의한 양(+)의 투자 성과를 갖는 경우는 양(+)의 모멘텀 이익을 지지하는 증거이고, 유의한 음(-)의 투자성과를 갖는 경우는 음(-)의 모멘텀 이익을 지지하는 증거로 해석된다. 또한, 거래량 회전율에 따라 구분된 주식집단들 간의 성과 비교를 통해, 투자자관심의 차이에 따른 모멘텀 효과의 차이도 함께 분석한다. 나아가 관찰된 모멘텀 이익의 가능한 원인을 파악하기 위하여 승자/패자 포트폴리오 성과의 분포 속성, 계절성 영향, 과거기간의 과잉반응 정도에 따른 미래 성과 차이, 처분효과(disposition effect)에 근거한 투자자의 매도경향 차이, 그리고 미래기간을 늘림에 따른 투자성과 패턴을 분석한다.

둘째, 본 연구에서는 주식시장의 동적 상황을 반영하여 조건부 모멘텀 효과를 분석한다. 행동재무모형에서 투자자관심은 시장상황 변화에 따른 위험회피성향의 변화에 영향을 받는 것으로 알려져 있다(Hong and Stein, 1999). Karlsson et al.(2009)는 타조효과(ostrich effect, Sedlacek, 2011)3)를 근거로, 투자자들은 좋은 뉴스에는 높은 관심을 보이지만 나쁜 뉴스는 회피하는 경향이 있다는 것을 언급하고, 투자자들은 하락시장에 비해 상승시장에서 더욱 빈번하게 그들의 포트폴리오를 조정한다는 것을 증거로 제시하였다. Cooper et al.(2004)는 과거 상승시장이 미래기간에 양(+)의 모멘텀 이익을 지속시킨다는 증거를 제시하였고, Asem and Tian(2010),

3) 타조효과는 위험에 처한 타조의 행동에서 찾는다. 즉, 타조는 날지 못하는 조류로 더운 날씨에 체온 조정을 위하여 모래에 머리를 박는 습성이 있다. 이는 어려움이 닥치면 현실을 회피하거나 문제를 회피해 버리는 경향을 비유된다. 
Investor Attention, Market Dynamics, and Momentum in the Korean Stock Market

Hanauer(2014), Lin et al.(2016)는 과거와 미래의 시장상황이 동일한 지속시장의 경우에 양(+)의 모멘텀 이익이 나타난다는 증거를 제시하였다. 한국 주식시장에서 외환위기 이후기간에서 양(+)의 모멘텀 이익을 보고한 $\operatorname{Kim}(2012), \operatorname{Eom}(2013)$ 의 결과도 상승시장의 특성에 기인할 수 있다.4) Hong and Stein(1999)은 과거기간의 시장상황에 관계없이 미래기간의 상승시장 여부가 양(+)의 모멘텀 이익 결정에 중요한 요인이라고 주장한다.5) 본 연구는 Cooper et al.(2004)의 방법에 근거하여 시장의 상승과 하락을 분류하고, 과거와 미래의 시장상황별 결합방법은 Asem and $\operatorname{Tian}(2010)$ 에 근거하여 설계한다. 상승과 하락의 시장상황 구분은 모멘텀 측정치를 산출하는 과거기간에서 시장지수의 보유기간성과가 양 $(+)$ 의 값을 갖는 경우는 상승시장으로, 음 $(-)$ 의 값을 갖는 경우는 하락시장으로 한다. 이러한 구분 기준은 미래 투자기간에 대한 상승/하락 시장의 구분에도 동일하게 적용한다. 이후 시장상황의 동적 특성에 따른 모멘텀 효과를 다음의 3 가지 관점으로 구분하여 분석한다. Cooper et al.(2004)에 근거한 과거기간의 상승/하락 시장상황 조건부 모멘텀 효과, Hong and Stein(1999)에 근거한 미래기간의 상승/하락 시장상황 조건부 모멘텀 효과, 그리고 Asem and Tian(2010), Hanauer(2014), Lin et al.(2016) 등에 근거한 과거-미래기간의 조합에 따른 상승/하락 시장상황 조건부 모멘텀 효과이다. 이를 통해 한국 주식시장에서 시장상황의 동적 특성이 모멘텀 이익에 미치는 영향을 검증할 수 있을 것이다.

셋째, 본 연구에서는 잔차모멘텀을 구성하여 모멘텀 효과에 대한 기업특성요인의 영향을 조사한다. Jegadeesh and Titman(1993)의 전통적 모멘텀 효과는 개별주식들의 수익률자료에 포함된 다양한 속성에 대한 통제가 없다. Blitz et al.(2011)은 가격결정모형에서 대표적인 3요인(시장위험프리미엄, 규모프리미엄, 가치프리미엄)을 제거한 후의 기업특성요인의 속성을 갖는 잔차수익률로부터 모멘텀 효과를 검증하였다. 즉, 잔차모멘텀(residual momentum)이다. 그들은 전통적 모멘텀 효과에 비하여 잔차모멘텀 효과가 보다 크게 나타나고 더욱이 시간가변적 상황에 영향을 덜 받는 안정적인 성과를 보인다는 증거를 제시한다. Chaves(2016)는 일본 주식시장에서 잔차모멘텀의 검증방법(CAPM을 이용한 잔차수익률 이용)을 이용할 경우 유의한 양 $(+)$ 의 모멘텀 이익을 관찰할 수 있다는 것을 보고한다. 본 연구는 Blitz et al.(2011)를 따라 Fama and French(1993)의 3요인 모형에 포함된 시장위험프리미엄, 규모프리미엄, 가치프리미엄을 제거한 잔차수익률을 이용하여 $3 \times 5$ 거래량-잔차모멘텀 포트폴리오를 구성하고 동일한 검증 과정을 수행한다.

4) 한국 주식시장에서 양(+)의 모멘텀 이익을 보고한 $\operatorname{Kim}(2012)$ 과 $\operatorname{Eom}(2013)$ 의 연구에서 외환위기 이후기간은 각각 1998.07 2008.05, 1998.07 2009.12이고, 동 기간에서 한국종합주가지수(KOSPI)는 각각 $493.4 \%$ 와 $390.1 \%$ 상승하였다. 이 기간은 KOSPI가 1,000 대 박스권에서 2,000 대 박스권으로 상승한 기간이기도 하며, 이 기간의 결과는 한국 주식시장의 상승기간에서 양 $(+)$ 의 모멘텀 이익을 보고한 Kang et al.(2014)의 연구와 일치하는 것이기도 하다. 본 연구에서는 주식시장의 동적 특성이 모멘텀 이익에 미치는 영향에 대한 분석을 본문의 '4. 주식시장 상황의 동적 특성과 모멘텀 효과'에서 구체적으로 실시한다.

5) 한편, Asem and Tian(2010)은 과거와 미래의 시장상황이 동일한 지속시장의 경우에도 일본 주식시장 에서는 음(-)의 모멘텀 이익이 관찰된다는 증거를 제시하고, 미국 주식시장에서 관찰된 동적 시장상황 조건부 모멘텀 이익은 일반적 증거가 아니라고 주장한다. 
한국증권학회지 제49권 4호 (2020)

넷째, 투자자관심의 대용변수인 거래량 회전율에 대한 강건성 검증을 한다. 거래량은 유동성과 변동성에 높은 관련성을 갖는 것으로 알려져 있다.6) Hou et al.(2009)과 Lin et al.(2016)은 거래량 회전율을 기반으로 구성된 모멘텀 포트폴리오로부터 관찰된 모멘텀 이익이 거래량과 다른 변수들 간의 상관관계에 영향을 받지 않음을 보고한다. 본 연구는 유동성과 변동성이 거래량과 갖는 관계를 통제하기 위하여 잔차거래량 회전율을 이용하여 모멘텀 포트폴리오를 구성하는 검증방법을 실증설계에 포함한다. 잔차거래량 회전율은 개별주식의 거래량 회전율 (종속변수)에 대한 변동성과 유동성의 횡단면 회귀분석으로부터 추정된 잔차이다. 변동성은 수익률의 표준편차를 이용하고, 유동성은 Amihud(2002)의 비유동성(illiquidity) 측정치를 이용한다. 횡단면 회귀분석으로부터 추정된 잔차거래량 회전율을 이용하여 3 가지 집단으로 구분하고, 각 잔차 거래량 회전율 주식집단 내에서 모멘텀 측정치를 기준으로 5 분위 포트폴리오를 구성한다. 즉, $3 \times 5$ 잔차거래량-모멘텀 포트폴리오를 이용하여 모멘텀 효과를 동일하게 확인한다.

주요 검증결과를 정리하면 다음과 같다. 첫째, 거래량 회전율을 기반으로 구성한 모멘텀 포트폴리오로부터의 투자성과 및 그 원인을 분석한 결과이다. $\mathrm{W}-\mathrm{L}$ 무비용포트폴리오는 음(-)의 투자성과를 보인다. 높은 거래량 회전율 주식집단 내에서의 $\mathrm{W}-\mathrm{L}$ 무비용포트폴리오는 모두 유의한 음(-)의 값을 갖지만, 낮은 거래량 회전율 주식집단 내에서는 대부분 비유의한 음 $(-)$ 의 값을 보인다. 즉, 한국 주식시장에서 투자자 관심이 높은 주식집단(높은 거래량 회전율 주식집단) 내에서 보다 강한 음(-)의 모멘텀 이익이 나타난다. 특히 음(-)의 모멘텀 이익은 패자포트폴리오의 강한 가격반전(하락 $\rightarrow$ 상승)에 의한 높은 양 $(+)$ 의 투자성과에 기인한다. 이러한 결과는 미래 보유기간의 장기화( 1 개월 $\rightarrow 12$ 개월)에 관계없이 일관되게 나타난다. 유의한 음(-)의 모멘텀 이익이 확인된 높은 거래량 회전율 주식집단 내에서 패자포트폴리오는 1월과 나머지 월 모두에서 유의한 투자성과를 갖지만, 승자포트폴리오는 1 월에서만 유의한 양(+)의 투자성과를 갖는다. 즉, 음(-)의 모멘텀 효과는 계절성(1월) 영향으로부터 의미 있는 영향을 받지 않는다.

둘째, 과거기간 승자포트폴리오와 패자포트폴리오를 구성하는 주식들에 있어서 초과수익률의 크기에 따라 과잉반응정도를 구분한 집단에서 승자/패자 포트폴리오 모두는 과거기간 과잉반응 정도가 높을수록 미래 보유기간에서 보다 높은 반전패턴을 보였다. 즉, 승자포트폴리오의 반전패턴(상승 $\rightarrow$ 하락)과 패자포트폴리오의 반전패턴(하락 $\rightarrow$ 상승)이 과거기간 이익/손실에 대한 투자자들의 과잉반응 정도에 밀접한 영향을 받는다. 또한 승자/패자 포트폴리오를 처분효과 관점에서 비교하면, 과거기간 승자포트폴리오의 구성주식들에 대해 투자자들은 높은 이익실현 경향(높은 매도경향)을 갖지만, 과거기간 패자포트폴리오의 구성주식들에 대해서는 높은 손실회피경향(낮은 매도경향)을 보인다. 특히, 처분효과 측정치의 크기를 비교하면, 패자포트 폴리오를 구성하는 주식들에 대한 손실회피경향의 강도가 승자포트폴리오를 구성하는 주식들에 대한 이익실현경향보다 높다.

6) Datar et al.(1998)는 거래량 회전율을 유동성의 대용변수로 이용하여, 유동성이 주식수익률의 횡단면 변동을 설명하는데 중요한 역할을 한다는 것을 제시했다. Shalen(1993)는 변동성과 거래량간의 상호관계에 있어서 투자자 관심의 차이가 거래량과 변동성 간의 양 $(+)$ 의 상관관계를 형성하는데 중요한 역할을 한다는 것을 보고한다. 
Investor Attention, Market Dynamics, and Momentum in the Korean Stock Market

셋째, 시장상황의 동적 특성이 모멘텀 효과에 미치는 영향을 분석한 결과는 한국 주식시장에서 과거기간과 미래기간의 상승/하락 시장상황 특성에 관계없이, 높은 거래량 회전율 주식집단 내에서 유의한 음(-)의 모멘텀 이익이 확인된다. 과거 시장상황과 미래 시장상황의 변화 방향 여부에 따라 구분된 지속시장과 전환시장에 대한 검증결과는 포트폴리오 형성기간에 관계없이 지속시장 보다는 전환시장에서 유의한 음(-)의 모멘텀 이익이 나타남을 보인다. 패자포트 폴리오는 지속시장 보다는 전환시장에서 유의한 양 $(+)$ 의 투자성과를 갖지만, 승자포트폴리오는 전환시장 보다 지속시장에서 유의한 양 $(+)$ 의 투자성과를 갖는다. 또 과거기간과 미래기간의 상승/하락의 4 가지 조합을 모두 고려한 경우 한국 주식시장에서 상승-상승, 상승-하락, 하락상승의 동적 시장상황별 모멘텀 효과는 대부분 유의한 음(-)의 모멘텀 이익을 보이지만, 하락하락의 경우에는 유의한 음(-)의 모멘텀 이익을 확인할 수 없다.

넷째, 모멘텀 효과에 대한 기업특성요인의 영향과 투자자 관심의 대용변수인 거래량 회전율에 대한 강건성을 조사한 검증결과이다. 먼저 기업특성요인의 영향을 조사한 검증결과에 의하면, 높은 거래량 회전율 주식집단 내에서 구성된 잔차모멘텀 포트폴리오는 유의한 음(-)의 투자성과를 보이지만, 낮은 거래량 회전율 주식집단에서는 유의한 음(-)의 모멘텀 이익을 확인할 수 없다. 즉, 한국 주식시장에서 확인되는 음(-)의 모멘텀 이익은 공통요인보다는 기업특성요인과 밀접한 관련을 갖는다. 강건성 검증을 위해 잔차거래량 회전율을 이용한 검증결과는 높은 잔차거래량 회전율을 갖는 주식집단 내에서 $\mathrm{W}-\mathrm{L}$ 무비용포트폴리오는 과거 형성기간에 관계없이 모두 유의한 음(-)의 투자성과를 보인다. 패자포트폴리오는 과거 형성기간에 관계없이 유의한 양 $(+)$ 의 투자성과를 갖지만, 승자포트폴리오는 유의한 성과를 갖지 않는다. 역시, 낮은 잔차 거래량 회전율을 갖는 주식집단 내에서는 모든 포트폴리오로부터 대부분 유의한 투자성과를 확인하기 어렵다. 결국, 한국 주식시장의 높은 거래량 회전율 주식집단에서 확인되는 유의한 음(-)의 모멘텀 이익은 개별주식의 변동성과 유동성 특성과는 관계없이 나타남을 보여준다.

본 논문의 구성은 다음과 같다. 서론에 이어, 다음 장에서는 검증과정에서 선택 및 이용된 자료들과 전체검증기간 및 하위기간의 구성 방법을 소개한다. 제 3 장에서는 거래량 회전율에 따라 구분된 주식집단 내에서 모멘텀 포트폴리오를 구성하여 한국 주식시장에서의 모멘텀 효과를 검증한다. 제 4장에서는 주식시장의 동적 상황의 특성에 모멘텀 효과가 어떤 영향을 받는지를 분석한다. 제 5 장에서는 기업특성요인과 거래량 회전율에 대한 영향요인을 통제한 잔차모멘텀을 구성하여 앞서 확인된 모멘텀 효과의 강건성을 검증한다. 마지막 장에서는 검증결과를 요약하고 그 시사점을 제시한다.

\section{2. 자료와 기간}

본 연구는 한국증권거래소가 개설한 유가증권시장과 코스닥시장에서 2000년 7월부터 2019년 6월까지의 기간 동안에 거래된 주식들을 표본자료로 이용한다. Fama and French(1992, 1993)에서와 같이, 금융업에 속한 주식들을 제외하고 동일조건의 회계자료 이용을 위하여 12 월 결산월을 갖는 주식들을 이용한다. 매우 높은 변동성을 갖는 주식들이 검증결과를 왜곡할 수 
한국증권학회지 제49권 4호 (2020)

있다는 Ang et al.(2006)의 결과에 기초하여 과거기간 수익률의 표준편차를 이용하여 구성된 10 분위 포트폴리오에서 가장 높은 변동성을 갖는 포트폴리오에 속한 주식들을 제외한다.7) 수익률은 검증과정에 포함된 개별주식의 월별수익률 자료를 이용한다. 시장수익률은 유가증권 시장과 코스닥시장에서 거래되는 모든 주식들의 가치가중방법으로부터 산출된 수익률을 이용한다. 시장프리미엄(market premium, RMRF)의 산출을 위한 무위험이자율은 통화안정 증권(364일)의 이자율을 이용한다. 한편, 미래기간 포트폴리오 투자성과의 측정치로 이용되는 위험조정수익률은 시장프리미엄을 이용한 자본자산가격결정모형(CAPM)과 시장프리미엄, 규모프리미엄(size premium, SMB), 가치프리미엄(value premium, HML)을 포함한 FamaFrench 3요인모형(FF3)을 이용하여 산출한다. 규모프리미엄과 가치프리미엄은 Fama and French(1993)의 연구에서 제시한 산출방법에 따라 유가증권시장과 코스닥시장에 거래된 모든 주식들을 대상으로 산출한다. 거래량 회전율은 Lee and Swaminathan(2000), Statman et al.(2006), Hou et al.(2009) 등에 근거하여 과거기간의 각 월에서 개별주식의 거래량을 발행 주식수로 나눈 값들을 평균한 값이다.

선행연구를 참고하여 전체 검증기간의 시작월은 아시아 외환위기의 영향과 회계자료로부터의 선견편의(look-ahead-bias)를 제거하기 위해 2000년 7월로 한다. Chui et al.(2000)는 아시아 지역의 주식시장에서 외환위기와 외국인에 대한 시장개방 이후 양(+)의 모멘텀 이익을 확인하기 어렵다는 결과를 보고했다. Choe et al.(1999)는 한국시장에서 1997년 외환위기 이전에 외국인은 모멘텀거래(positive feedback trading)를 하지만, 외환위기 이후에는 이러한 거래행위는 대부분 사라진다는 것을 보고한다. $\operatorname{Kim}(2012), \operatorname{Eom}(2013)$ 등은 개인투자자의 영향력이 낮아진 외환위기 이후기간(1998년 7월 이후)에서 계속투자전략이 유의적인 투자전략임을 보도한다. 1999년 4월 12월의 표본기간에 대한 연구에서 $\operatorname{Kim}(2000)$ 는 주별자료를 이용하여 모멘텀거래(relative strength strategies)로부터의 초과이익을 보고한다.

하위기간은 검증월(t)인 7월을 기준으로 과거 포트폴리오 형성기간과 미래 포트폴리오 보유기간으로 구성된다. 과거기간의 포트폴리오 형성기간은 12 개월, 6 개월, 3 개월의 3 가지이고, 미래기간의 포트폴리오 보유기간은 1 개월, 3 개월, 6 개월, 12 개월의 4 가지이다. 모멘텀 측정치는 검증월 $(\mathrm{t}, 7$ 월)의 직전 월(t-1, 6 월)을 제외한 기간 동안의 보유기간성과이다. 예를 들어, 12 개월 형성기간의 경우는 $\mathrm{t}-12 \sim \mathrm{t}-2$ 의 11 개월 동안에 계산된 보유기간수익률을 모멘텀 측정치로

7) Park and Jee(2006)는 한국 주식시장에서 낮은 시장변동성이 관찰되는 기간과 낮은 변동성을 갖는 개별주식들로 구성된 포트폴리오에서 계속투자전략(모멘텀)이 유의한 투자전략임을 제시하였다. 반면에, 높은 시장변동성이 관찰되는 기간과 높은 변동성을 갖는 개별주식들로 구성된 포트폴리오에 있어서 반대투자전략(반전)이 유의한 투자전략이라는 증거를 보고한다. 즉, Park and Jee(2006)에 근거하면, 본 연구의 경우 Ang et al.(2006)에 따라 높은 변동성을 갖는 개별주식들을 분석대상에서 제외하였기 때문에, 반대투자전략(반전) 보다는 계속투자전략(모멘텀)의 성과가 관찰될 가능성이 보다 높다. 한편, Eom et al.(2019)은 최근 한국 주식시장에서 거래되는 개별주식들 간의 상관관계는 낮아지지만 개별주식의 고유변동성(idiosyncratic volatility)이 높은 수준을 유지하기 때문에, 시장변동성이 높아지는 경향이 있다는 결과를 보고하였다. 이는 높은 변동성을 갖는 주식들을 통제하는 경우 Park and Jee(2006)에서 보인 양(+)의 모멘텀 이익이 장기적으로 나타나기 어려움을 의미한다. 
Investor Attention, Market Dynamics, and Momentum in the Korean Stock Market

이용한다. 이유는 널리 알려진 시장미시구조 편의와 단기반전 효과를 통제하기 위하여 직전 월을 제외한다. 하위기간의 이동방법은 보유기간이 겹치지 않는 방법(non-overlapping holding period)을 채택한다. 즉, 보유기간 1 개월의 경우에 228 개 하위기간에서 반복적으로 설계된 검증과정을 수행하고, 보유기간 12 개월의 경우는 19 개 하위기간에서 검증과정을 수행한다.

\section{3. 투자자관심이 모멘텀 효과에 미치는 영향}

\section{1 거래량 포트폴리오와 모멘텀 포트폴리오}

본 절에서는 주요 관찰대상인 거래량-모멘텀 기준으로 구성된 $3 \times 5$ 포트폴리오로부터의 검증결과를 살펴보기 전에 거래량 기준 포트폴리오와 모멘텀 기준 포트폴리오로부터 관찰된 결과를 먼저 살펴본다. <표 $1>$ 은 거래량 회전율 기준으로 구성된 5 분위 포트폴리오의 분석결과를, <표 2>는 모멘텀 측정치에 기준하여 구성된 5 분위 포트폴리오의 분석결과를 나타낸다. 표에는 5 분위 포트폴리오에 대한 과거기간의 거래량 회전율과 모멘텀 측정치, 무위험자산에 대한 초과수익률, 그리고 미래기간의 3가지 투자성과 측정치인 초과수익률과 CAPM과 FF3로부터의 위험조정수익률(알파)을 구분 제시한다. 포트폴리오 형성기간은 12 개월(Panel A), 6개월(Panel $\mathrm{B}), 3$ 개월(Panel C)의 3 가지로 구분하였고, 포트폴리오 보유기간은 1 개월이다. 본 연구는 보수적 관점에서 이분산성과 자기상관성을 조정한 Newey and West $(1987,1994)$ 의 표준오차로부터 산출된 $\mathrm{t}$-통계량에 근거하여 3가지 투자성과가 모두 동일한 부호를 갖고 유의한 경우에 한하여 유의한 검증결과로 평가한다.

<표 1>을 보면 Statman et al.(2006)에서와 같이 과거기간의 거래량 회전율이 높을수록 미래기간에 높은 초과수익률과 위험조정수익률을 갖는 경향을 보인다. 하지만, 거래량 회전율이 가장 높은 포트폴리오와 가장 낮은 포트폴리오 간의 성과 차이는 3 가지 측정치(초과수익률, $\mathrm{CAPM}$ 알파, $\mathrm{FF} 3$ 알파) 모두에서 유의하게 나타나지는 않는다. 한편, 과거기간 초과수익률은 거래량 회전율과 분명한 관계를 확인할 수 없다. 따라서 거래량 포트폴리오의 미래기간 투자성과가 과거기간 초과수익률과 체계적인 관련을 갖는다고 보기 어렵다. Jegadeesh and Titman(1993)의 방법에 따라 모멘텀 측정치를 기준으로 구성된 5 분위 포트폴리오에 대한 분석결과를 <표 $2>$ 에서 살펴본다.

<표 2>에서 모멘텀 포트폴리오는 한국 주식시장에서 일반적으로 보고된 유의한 음(-)의 모멘텀 이익을 보여준다. 즉, 과거 형성기간 $(12 \mathrm{M}, 6 \mathrm{M}, 3 \mathrm{M})$ 에 관계없이 과거기간에서 높은 모멘텀 측정치를 갖는 승자포트폴리오는 높은 초과수익률을 갖고, 낮은 모멘텀 측정치를 갖는 패자포트폴리오는 낮은 초과수익률을 갖는다. 따라서 승자포트폴리오와 패자포트폴리오 간의 차이인 W-L 무비용 포트폴리오는 매우 유의하며 큰 양(+)의 값을 갖는다. 하지만 미래기간에 승자포트폴리오와 패자포트폴리오는 과거기간과 대조적인 성과를 보인다. 승자포트폴리오는 미래기간에서도 양 $(+)$ 의 투자성과를 갖기는 하나 그 성과는 과거기간에 비교하여 매우 큰 폭의 하락을 경험한다. 패자포트폴리오의 성과는 과거기간에 비교하여 미래기간에 매우 큰 폭의 상승을 보여 유의한 양 $(+)$ 의 값을 갖는다. 따라서 미래기간에서 $\mathrm{W}-\mathrm{L}$ 무비용 포트폴리오는 
〈표 1〉거래량 기준 5 분위 포트폴리오의 분석결과

표는 거래량 회전율 기준으로 구성된 5분위 포트폴리오에 대한 분석결과이다. 거래량 회전율은 검증월(7월) 이전 포트폴리오 형성기간(12개월, 6 개월, 3 개월)동안의 월별 거래량을 발행주식수로 나눈 값의 기간 평균값이다. 표는 3 가지 포트폴리오 형성기간 $(12 \mathrm{M}, 6 \mathrm{M}, 3 \mathrm{M})$ 별 미래 보유기간 1 개월(1M)에 대한 결과를 나타낸다. 보고수치는 과거기간의 거래량 회전율과 초과수익률, 보유기간의 초과수익률과 3 가지 투자성과 측정치인 무위험 초과수익률, $\mathrm{CAPM}$ 위험조정수익률(CAPM a), Fama \& French 3요인모형 위험조정 수익률(FF3 a)이다. 괄호 속의 t-통계량은 자기상관성과 이분산성을 Newey and West(1994)의 방법으로 조정한 값이다. $10 \%, 5 \%, 1 \%$ 수준의 유의성을 각각 ${ }^{*},{ }^{* *},{ }^{* * *}$ 로 구분 표시한다.

\begin{tabular}{|c|c|c|c|c|c|c|}
\hline & highest & 2 & 3 & 4 & lowest & $\mathrm{H}-\mathrm{L}$ \\
\hline \multicolumn{7}{|c|}{ Panel A: $12 \mathrm{M} / 1 \mathrm{M}$ 횡단면 거래량 회전율 포트폴리오 } \\
\hline 과거 거래량 회전율 & $\begin{array}{l}5.2595^{\text {**** }} \\
(21.90)\end{array}$ & $\begin{array}{l}0.4728^{* * *} \\
(33.60)\end{array}$ & $\begin{array}{l}0.1950^{* * *} \\
(34.32)\end{array}$ & $\begin{array}{l}0.0833^{* * *} \\
(36.44)\end{array}$ & $\begin{array}{l}0.0212^{\text {*** }} \\
(30.58)\end{array}$ & $\begin{array}{l}5.2382^{* * * *} \\
(21.86)\end{array}$ \\
\hline 과거 초과수익률 & $\begin{array}{r}0.0223 \\
(1.07)\end{array}$ & $\begin{array}{c}0.0620^{* * *} \\
(2.99)\end{array}$ & $\begin{array}{c}0.0621^{* * *} \\
(3.17)\end{array}$ & $\begin{array}{c}0.0486^{* * *} \\
(2.92)\end{array}$ & $\begin{array}{c}0.0374^{* *} \\
(2.53)\end{array}$ & $\begin{array}{r}-0.0152 \\
(-1.27)\end{array}$ \\
\hline 초과수익률 & $\begin{array}{l}0.0290^{* * * *} \\
(3.74)\end{array}$ & $\begin{array}{c}0.0149^{* *} \\
(2.43)\end{array}$ & $\begin{array}{c}0.0162^{* * *} \\
(3.20)\end{array}$ & $\begin{array}{l}0.0139^{* * *} \\
(3.18)\end{array}$ & $\begin{array}{l}0.0120^{* * *} \\
(3.14)\end{array}$ & $\begin{array}{l}0.0170^{\text {*** }} \\
(2.82)\end{array}$ \\
\hline CAPM a & $\begin{array}{c}0.0231^{* * * *} \\
(3.38)\end{array}$ & $\begin{array}{c}0.0096^{*} \\
(1.94)\end{array}$ & $\begin{array}{c}0.0114^{* * *} \\
(3.23)\end{array}$ & $\begin{array}{c}0.0098^{* * * *} \\
(3.28)\end{array}$ & $\begin{array}{c}0.0088^{* *} \\
(2.25)\end{array}$ & $\begin{array}{c}0.0143^{* *} \\
(2.12)\end{array}$ \\
\hline FF3 a & $\begin{array}{c}0.0181^{* * *} \\
(2.86)\end{array}$ & $\begin{array}{c}0.0054^{*} \\
(1.87)\end{array}$ & $\begin{array}{c}0.0077^{* * * *} \\
(3.22)\end{array}$ & $\begin{array}{l}0.0067^{* * *} \\
(3.51)\end{array}$ & $\begin{array}{c}0.0065^{* *} \\
(2.20)\end{array}$ & $\begin{array}{r}0.0116 \\
(1.64)\end{array}$ \\
\hline \multicolumn{7}{|c|}{ Panel B: 6M/1M 횡단면 거래량 회전율 포트폴리오 } \\
\hline 과거 거래량 회전율 & $\begin{array}{l}5.1213^{* * *} \\
(20.33)\end{array}$ & $\begin{array}{l}0.4305^{\text {*** }} \\
(31.71)\end{array}$ & $\begin{array}{l}0.1744^{* * *} \\
(32.55)\end{array}$ & $\begin{array}{l}0.0741^{* * *} \\
(33.48)\end{array}$ & $\begin{array}{l}0.0183^{\text {*** }} \\
(28.03)\end{array}$ & $\begin{array}{l}5.1030^{\text {**** }} \\
(20.30)\end{array}$ \\
\hline 과거 초과수익률 & $\begin{array}{r}0.0076 \\
(0.53)\end{array}$ & $\begin{array}{c}0.0284^{* *} \\
(2.04)\end{array}$ & $\begin{array}{r}0.0190 \\
(1.54)\end{array}$ & $\begin{array}{r}0.0159 \\
(1.44)\end{array}$ & $\begin{array}{r}0.0070 \\
(0.73)\end{array}$ & $\begin{array}{r}0.0006 \\
(0.07)\end{array}$ \\
\hline 초과수익률 & $\begin{array}{l}0.0228^{* * *} \\
(3.02)\end{array}$ & $\begin{array}{c}0.0155^{\text {*** }} \\
(2.58)\end{array}$ & $\begin{array}{c}0.0150^{\text {*** }} \\
(2.92)\end{array}$ & $\begin{array}{l}0.0129^{* * *} \\
(3.00)\end{array}$ & $\begin{array}{l}0.0122^{* * *} \\
(3.19)\end{array}$ & $\begin{array}{c}0.0106^{*} \\
(1.86)\end{array}$ \\
\hline CAPM a & $\begin{array}{c}0.0170^{* * * *} \\
(2.60)\end{array}$ & $\begin{array}{c}0.0102^{* *} \\
(2.48)\end{array}$ & $\begin{array}{c}0.0102^{* * *} \\
(2.88)\end{array}$ & $\begin{array}{c}0.0088^{* * *} \\
(3.03)\end{array}$ & $\begin{array}{c}0.0090^{* *} \\
(2.44)\end{array}$ & $\begin{array}{r}0.0081 \\
(1.28)\end{array}$ \\
\hline FF3 a & $\begin{array}{c}0.0112^{* *} \\
(2.07)\end{array}$ & $\begin{array}{c}0.0064^{* *} \\
(2.38)\end{array}$ & $\begin{array}{c}0.0062^{* * *} \\
(2.81)\end{array}$ & $\begin{array}{c}0.0059^{* * *} \\
(3.18)\end{array}$ & $\begin{array}{c}0.0067^{* *} \\
(2.43)\end{array}$ & $\begin{array}{r}0.0045 \\
(0.70)\end{array}$ \\
\hline \multicolumn{7}{|c|}{ Panel C: 3M/1M 횡단면 거래량 회전율 포트폴리오 } \\
\hline 과거 거래량 회전율 & $\begin{array}{l}4.9748^{* * *} \\
(18.89)\end{array}$ & $\begin{array}{l}0.3930^{* * *} \\
(30.66)\end{array}$ & $\begin{array}{l}0.1579^{* * *} \\
(32.20)\end{array}$ & $\begin{array}{l}0.0668^{* * *} \\
(31.93)\end{array}$ & $\begin{array}{l}0.0160^{* * * *} \\
(27.14)\end{array}$ & $\begin{array}{l}4.9587^{* * * *} \\
(18.87)\end{array}$ \\
\hline 과거 초과수익률 & $\begin{array}{r}-0.0016 \\
(-0.19)\end{array}$ & $\begin{array}{r}0.0051 \\
(0.64)\end{array}$ & $\begin{array}{r}0.0021 \\
(0.30)\end{array}$ & $\begin{array}{l}-0.0028 \\
(-0.44)\end{array}$ & $\begin{array}{r}-0.0069 \\
(-1.29)\end{array}$ & $\begin{array}{r}0.0054 \\
(1.16)\end{array}$ \\
\hline 초과수익률 & $\begin{array}{c}0.0183^{* *} \\
(2.48)\end{array}$ & $\begin{array}{l}0.0171^{* * *} \\
(2.74)\end{array}$ & $\begin{array}{c}0.0145^{\text {*** }} \\
(2.96)\end{array}$ & $\begin{array}{l}0.0138^{\text {*** }} \\
(3.21)\end{array}$ & $\begin{array}{l}0.0118^{* * *} \\
(3.04)\end{array}$ & $\begin{array}{r}0.0065 \\
(1.23)\end{array}$ \\
\hline CAPM a & $\begin{array}{c}0.0123^{* * *} \\
(2.60)\end{array}$ & $\begin{array}{c}0.0114^{* *} \\
(2.49)\end{array}$ & $\begin{array}{c}0.0099^{* * *} \\
(2.99)\end{array}$ & $\begin{array}{c}0.0097^{* * * *} \\
(3.26)\end{array}$ & $\begin{array}{c}0.0086^{* *} \\
(2.28)\end{array}$ & $\begin{array}{r}0.0037 \\
(1.00)\end{array}$ \\
\hline FF3 a & $\begin{array}{c}0.0073^{* *} \\
(2.52)\end{array}$ & $\begin{array}{c}0.0073^{* * *} \\
(2.80)\end{array}$ & $\begin{array}{c}0.0060^{\text {*** }} \\
(3.18)\end{array}$ & $\begin{array}{c}0.0071^{* * *} \\
(3.63)\end{array}$ & $\begin{array}{c}0.0061^{* *} \\
(2.16)\end{array}$ & $\begin{array}{r}0.0013 \\
(0.34)\end{array}$ \\
\hline
\end{tabular}


Investor Attention, Market Dynamics, and Momentum in the Korean Stock Market

〈표 2〉모멘텀 기준 5 분위 포트폴리오의 분석결과

표는 횡단면 모멘텀 측정치를 기준으로 구성된 5 분위 포트폴리오에 대한 분석결과를 보고한다. 모멘텀 측정치는 검증월(7월)의 직전 월(t-1)을 제외한 3 가지 과거기간 $(12 \mathrm{M}, 6 \mathrm{M}, 3 \mathrm{M})$ 동안의 보유기간수익률이다. 표는 포트폴리오 형성기간별 미래 보유기간 1 개월( $1 \mathrm{M})$ 에 대한 결과를 나타낸다. 직전월 $(\mathrm{t}-1)$ 은 시장미시 구조편의와 단기반전효과를 통제하기 위하여 제외한다. 보고수치는 과거기간에서 모멘텀 측정치와 보유기간 무위험 초과수익률, 미래 보유기간에서 3가지 투자성과 측정치인 무위험 초과수익률, CAPM 위험조정수익률(CAPM a), Fama \& French 3요인모형 위험조정수익률(FF3 a)이다. 괄호 안의 t-값은 자기상관성과 이분산성을 Newey and West(1994)의 방법으로 조정한 값이다. $10 \%, 5 \%, 1 \%$ 수준의 유의성을 각각 ${ }^{*},{ }^{* *},{ }^{* * *}$ 로 구분 표시한다.

\begin{tabular}{|c|c|c|c|c|c|c|}
\hline & highest & 2 & 3 & 4 & lowest & $\mathrm{H}-\mathrm{L}$ \\
\hline \multicolumn{7}{|c|}{ Panel A: 12M/1M 횡단면 모멘텀 포트폴리오 } \\
\hline 과거 모멘텀 측정치 & $\begin{array}{l}0.8553^{* * *} \\
(24.32)\end{array}$ & $\begin{array}{c}0.1968^{* * *} \\
(9.91)\end{array}$ & $\begin{array}{r}-0.0201 \\
(-1.30)\end{array}$ & $\begin{array}{l}-0.1917^{\text {*** }} \\
(-14.54)\end{array}$ & $\begin{array}{l}-0.4322^{* * *} \\
(-39.07)\end{array}$ & $\begin{array}{l}1.2875^{\text {*** }} \\
(45.42)\end{array}$ \\
\hline 과거 초과수익률 & $\begin{array}{l}0.7960^{\text {*** }} \\
(23.33)\end{array}$ & $\begin{array}{c}0.1578^{* * *} \\
(8.13)\end{array}$ & $\begin{array}{l}-0.0521^{\text {*** }} \\
(-3.42)\end{array}$ & $\begin{array}{l}-0.2182^{* * *} \\
(-16.75)\end{array}$ & $\begin{array}{l}-0.4509^{* * *} \\
(-41.17)\end{array}$ & $\begin{array}{l}1.2469^{\text {*** }} \\
(45.69)\end{array}$ \\
\hline 초과수익률 & $\begin{array}{c}0.0119^{* *} \\
(2.22)\end{array}$ & $\begin{array}{l}0.0159^{* * *} \\
(3.50)\end{array}$ & $\begin{array}{l}0.0126^{* * *} \\
(2.79)\end{array}$ & $\begin{array}{c}0.0129^{* *} \\
(2.49)\end{array}$ & $\begin{array}{l}0.0327^{* * *} \\
(4.26)\end{array}$ & $\begin{array}{l}-0.0208^{* * *} \\
(-3.67)\end{array}$ \\
\hline CAPM a & $\begin{array}{c}0.0069^{*} \\
(1.79)\end{array}$ & $\begin{array}{c}0.0119^{* * *} \\
(3.33)\end{array}$ & $\begin{array}{c}0.0085^{* * *} \\
(2.74)\end{array}$ & $\begin{array}{c}0.0083^{*} \\
(1.82)\end{array}$ & $\begin{array}{l}0.0271^{* * *} \\
(3.44)\end{array}$ & $\begin{array}{c}-0.0202^{* *} \\
(-2.43)\end{array}$ \\
\hline FF3 a & $\begin{array}{r}0.0038 \\
(1.17) \\
\end{array}$ & $\begin{array}{l}0.0087^{* * *} \\
(3.51)\end{array}$ & $\begin{array}{l}0.0051^{* * *} \\
(2.74)\end{array}$ & $\begin{array}{c}0.0045^{*} \\
(1.79)\end{array}$ & $\begin{array}{c}0.0224^{* * *} \\
(3.17)\end{array}$ & $\begin{array}{c}-0.0187^{* *} \\
(-2.28)\end{array}$ \\
\hline \multicolumn{7}{|c|}{ Panel B: 6M/1M 횡단면 모멘텀 포트폴리오 } \\
\hline 과거 모멘텀 측정치 & $\begin{array}{l}0.4835^{\text {*** }} \\
(23.17)\end{array}$ & $\begin{array}{c}0.1174^{* * *} \\
(9.21)\end{array}$ & $\begin{array}{r}-0.0152 \\
(-1.44)\end{array}$ & $\begin{array}{l}-0.1278^{* * *} \\
(-13.22)\end{array}$ & $\begin{array}{l}-0.3039^{* * *} \\
(-33.65)\end{array}$ & $\begin{array}{l}0.7874^{\text {*** }} \\
(48.15)\end{array}$ \\
\hline 과거 초과수익률 & $\begin{array}{l}0.4626^{\text {*** }} \\
(22.50)\end{array}$ & $\begin{array}{l}0.1010^{* * *} \\
(7.99)\end{array}$ & $\begin{array}{c}-0.0299^{* * *} \\
(-2.85)\end{array}$ & $\begin{array}{l}-0.1410^{* * *} \\
(-14.59)\end{array}$ & $\begin{array}{l}-0.3148^{* * *} \\
(-34.80)\end{array}$ & $\begin{array}{l}0.7774^{* * *} \\
(48.48)\end{array}$ \\
\hline 초과수익률 & $\begin{array}{c}0.0091^{*} \\
(1.90)\end{array}$ & $\begin{array}{l}0.0119^{* * * *} \\
(2.68)\end{array}$ & $\begin{array}{l}0.0125^{* * *} \\
(2.72)\end{array}$ & $\begin{array}{l}0.0151^{* * *} \\
(2.85)\end{array}$ & $\begin{array}{l}0.0297^{* * *} \\
(3.72)\end{array}$ & $\begin{array}{l}-0.0207^{\text {*** }} \\
(-3.43)\end{array}$ \\
\hline CAPM a & $\begin{array}{r}0.0047 \\
(1.42)\end{array}$ & $\begin{array}{c}0.0078^{* *} \\
(2.31)\end{array}$ & $\begin{array}{c}0.0084^{* *} \\
(2.30)\end{array}$ & $\begin{array}{c}0.0104^{* * *} \\
(2.63)\end{array}$ & $\begin{array}{l}0.0238^{* * *} \\
(3.16)\end{array}$ & $\begin{array}{c}-0.0192^{* *} \\
(-2.44)\end{array}$ \\
\hline FF3 a & $\begin{array}{r}0.0016 \\
(0.66) \\
\end{array}$ & $\begin{array}{c}0.0048^{* *} \\
(2.21)\end{array}$ & $\begin{array}{l}0.0049^{* * *} \\
(2.70)\end{array}$ & $\begin{array}{l}0.0064^{\text {**** }} \\
(2.67)\end{array}$ & $\begin{array}{c}0.0186^{* * *} \\
(2.70)\end{array}$ & $\begin{array}{c}-0.0169^{* *} \\
(-2.17)\end{array}$ \\
\hline \multicolumn{7}{|c|}{ Panel C: 3M/1M 횡단면 모멘텀 포트폴리오 } \\
\hline 과거 모멘텀 측정치 & $\begin{array}{l}0.2605^{\text {**** }} \\
(25.97)\end{array}$ & $\begin{array}{c}0.0658^{* * * *} \\
(9.34)\end{array}$ & $\begin{array}{c}-0.0129^{* *} \\
(-2.02)\end{array}$ & $\begin{array}{l}-0.0830^{\text {*** }} \\
(-13.31)\end{array}$ & $\begin{array}{l}-0.2047^{* * *} \\
(-32.34)\end{array}$ & $\begin{array}{l}0.4652^{* * *} \\
(62.78)\end{array}$ \\
\hline 과거 초과수익률 & $\begin{array}{l}0.2538^{* * * *} \\
(25.41)\end{array}$ & $\begin{array}{l}0.0597^{* * *} \\
(8.47)\end{array}$ & $\begin{array}{c}-0.0188^{* * *} \\
(-2.95)\end{array}$ & $\begin{array}{l}-0.0887^{* * *} \\
(-14.16)\end{array}$ & $\begin{array}{l}-0.2099^{* * *} \\
(-32.94)\end{array}$ & $\begin{array}{l}0.4637^{\text {*** }} \\
(62.93)\end{array}$ \\
\hline 초과수익률 & $\begin{array}{c}0.0124^{* *} \\
(2.56)\end{array}$ & $\begin{array}{c}0.0096^{* *} \\
(2.17)\end{array}$ & $\begin{array}{c}0.0139^{* * *} \\
(2.99)\end{array}$ & $\begin{array}{c}0.0143^{* * *} \\
(2.72)\end{array}$ & $\begin{array}{c}0.0253^{* * *} \\
(3.35)\end{array}$ & $\begin{array}{l}-0.0129^{* * *} \\
(-2.58)\end{array}$ \\
\hline CAPM a & $\begin{array}{c}0.0079^{* *} \\
(2.27)\end{array}$ & $\begin{array}{c}0.0055^{*} \\
(1.87)\end{array}$ & $\begin{array}{c}0.0097^{* * *} \\
(2.70)\end{array}$ & $\begin{array}{c}0.0096^{* *} \\
(2.45)\end{array}$ & $\begin{array}{c}0.0192^{* * *} \\
(3.23)\end{array}$ & $\begin{array}{c}-0.0113^{* *} \\
(-2.39)\end{array}$ \\
\hline FF3 a & $\begin{array}{c}0.0049^{*} \\
(1.93)\end{array}$ & $\begin{array}{r}0.0024 \\
(1.25)\end{array}$ & $\begin{array}{c}0.0063^{* * *} \\
(3.12)\end{array}$ & $\begin{array}{c}0.0054^{* *} \\
(2.40)\end{array}$ & $\begin{array}{c}0.0149^{* * *} \\
(3.45)\end{array}$ & $\begin{array}{c}-0.0100^{* *} \\
(-2.19)\end{array}$ \\
\hline
\end{tabular}


한국증권학회지 제49권 4호 (2020)

유의한 음(-)의 값을 갖는다. Asem and Tian(2010)은 미국 주식시장에서 승자포트폴리오는 미래기간에 하락하는 투자성과를 보이고, 패자포트폴리오는 상승하는 투자성과를 보이나 W-L 무비용포트폴리오는 여전히 양(+)의 모멘텀 이익을 가짐을 보여준다.8) <표 $2>$ 의 결과는 한국 주식시장에서도 승자포트폴리오와 패자포트폴리오의 미래성과가 Asem and Tian(2010)과 유사하게 변화하는 모습을 보이지만 $\mathrm{W}-\mathrm{L}$ 무비용 포트폴리오의 성과는 미국시장의 결과와는 대비되게 유의한 음 $(-)$ 의 값을 가짐을 보여주는 것이다. 다음 절에서 음 $(-)$ 의 모멘텀 이익에 대한 가능한 원인을 거래량-모멘텀 포트폴리오를 이용하여 단계적으로 확인한다.

\section{2 거래량-모멘텀 포트폴리오}

본 절은 거래량 회전율을 이용하여 분류된 주식집단 내에서 횡단면 5 분위 모멘텀 포트폴리오를 구성하여 한국 주식시장에서의 모멘텀 효과를 조사한 결과를 제시한다. 즉, $3 \times 5$ 거래량-모멘텀 포트폴리오에 대한 분석결과이다. Daniel et al.(1998)의 과잉신뢰 가설과 Lee and Swaminathan (2000), Statman et al.(2006), Hou et al.(2009)의 연구는 투자자 관심이 낮은 주식집단보다 투자자 관심이 높은 주식집단에서 모멘텀 효과가 강하게 발생함을 보여준다, 따라서 $3 \times 5$ 거래량-모멘텀 포트폴리오 분석에서 $\mathrm{W}-\mathrm{L}$ 무비용포트폴리오의 성과가 유의한 양 $(+)$ 의 값을 보인다면, Jegadeesh and Titman(1993)과 같은 양(+)의 모멘텀 이익을 지지하는 증거이고, 유의한 음(-)의 값을 보인다면, 음(-)의 모멘텀 이익을 지지하는 증거이다. 각 증거는 다음과 같이 해석할 수 있다.

과잉신뢰 가설에 근거한 양(+)의 모멘텀 이익은 다음과 같다. 과거기간에 높은 성과를 실현한 승자포트폴리오 구성 주식에 대해, 투자자들의 낙관적인 과잉신뢰(optimistic overconfidence)에 따른 높은 매수경향이 주가의 과잉반응(optimistic bias-driven overreaction)을 야기하고, 이러한 과잉반응은 미래기간에도 지속됨(extrapolative expectation)에 따라 승자포트폴리오는 높은 성과를 유지한다. 반면, 과거기간에 낮은 성과를 실현한 패자포트폴리오의 구성주식에 대해 투자자들의 비관적인 과잉신뢰(pessimistic overconfidence)에 따른 높은 매도경향이 주가의 과잉반응을 야기하고, 이러한 과잉반응이 미래기간에도 지속됨에 따라 패자포트폴리오는 낮은 투자성과를 유지한다. 결국, $\mathrm{W}-\mathrm{L}$ 무비용포트폴리오는 미래기간에 양 $(+)$ 의 모멘텀 이익을 실현하고, 이후 장기 반전이 나타난다. 또한 $\mathrm{W}-\mathrm{L}$ 무비용포트폴리오가 갖는 양 $(+)$ 의 모멘텀 이익은 승자포트폴리오에서 나타나는 미래기간 지속적인 양(+)의 투자성과에 강하게 의존한다. 한편, 한국 주식시장에서 관찰되는 것과 같은 음(-)의 모멘텀 이익은 다음과 같이 설명될 수 있다. 과거기간에 높은 성과를 실현한 승자포트폴리오에 대한 투자자들의 낙관적인 과잉신뢰에 따른 높은 매수세는 주식가격에 지나친 과잉반응을 야기하고, 이에 따른 승자포트폴리오에 대한 투자자들의 매도 증가가 미래 보유기간에서 승자포트폴리오의 빠른 가격하락으로 이어져 투자성과가 큰 폭으로 하락한다. 반면에, 과거기간에 낮은 성과를 실현한 패자포트폴리오에

8) Asem and Tian(2010)의 결과(p.1556)를 살펴보면, 승자포트폴리오는 과거/미래의 시장상황에 관계없이 과거기간에 비교하여 미래기간의 투자성과가 모두 감소하는 패턴을 보이고, 반면에 패자포트 폴리오는 과거/미래의 시장상황에 관계없이 미래기간의 투자성과가 증가하는 패턴을 보인다. 
Investor Attention, Market Dynamics, and Momentum in the Korean Stock Market

대한 투자자들의 비관적인 과잉신뢰에 따른 높은 매도세는 주가의 지나친 하락(과잉반응)을 야기하고, 이로 인해 미래 보유기간에서 빠른 조정과정을 통해 패자포트폴리오의 성과는 큰 폭의 상승으로 반전한다. 결국, $\mathrm{W}-\mathrm{L}$ 무비용포트폴리오는 미래기간에 음 $(-)$ 의 모멘텀 이익을 갖고, 이러한 음(-)의 모멘텀 이익은 패자포트폴리오의 성과가 미래기간에 큰 폭으로 상승반전 하는 특성에 강하게 의존한다.

<표 $3>$ 은 거래량 회전율을 이용한 $3 \times 5$ 거래량-모멘텀 포트폴리오에 대한 검증결과를 제시한다. 검증기간(2000.07 2019.06)에 있어서 4가지 포트폴리오 형성기간(12M, $6 \mathrm{M}, 3 \mathrm{M}$, $1 \mathrm{M})$ 에 대한 미래 포트폴리오 보유기간 1 개월 $(1 \mathrm{M})$ 의 4 가지 모멘텀 투자전략 $(12 \mathrm{M} / 1 \mathrm{M}, 6 \mathrm{M} / 1 \mathrm{M}$, $3 \mathrm{M} / 1 \mathrm{M}, 1 \mathrm{M} / 1 \mathrm{M})$ 으로부터 관찰된 모멘텀 이익을 보고한다. 과거 형성기간 1 개월을 포함한 이유는 단기반전현상의 확인과 함께 모멘텀 검증방법의 신뢰성을 확보하기 위해서 이다.9) 표에서 거래량 회전율 주식집단은 상위 $30 \%$ 의 높은 거래량 회전율을 갖는 주식집단과 하위 $30 \%$ 의 낮은 거래량 회전율을 갖는 주식집단으로 구분한다. 과거기간에 있어서 모멘텀 측정치와 보유기간 초과수익률의 2 가지 결과를 제시하고, 미래기간에 3가지 투자성과 측정치인 보유기간 초과수익률, $\mathrm{CAPM}$ 위험조정수익률, $\mathrm{FF} 3$ 위험조정수익률을 제시한다. 보수적인 평가를 위해 3가지 투자 성과가 모두 동일한 부호를 갖고 통계적으로 유의한 경우에 한하여 유의한 결과로 평가한다.

<표 3>을 보면 포트폴리오 형성기간과 거래량 회전율에 관계없이, 미래 보유기간 1 개월에 $\mathrm{W}-\mathrm{L}$ 무비용포트폴리오는 음(-)의 성과를 갖는다. 거래량 회전율에 따른 주식집단 비교에서, 높은 거래량 회전율 주식집단에 대한 $\mathrm{W}-\mathrm{L}$ 무비용포트폴리오는 모두 유의한 음(-)의 값을 갖지만, 낮은 거래량 회전율 주식집단은 대부분 비유의한 음(-)의 값을 갖는다. 즉, 한국 주식시장 에서 투자자 관심이 높은 주식집단 내에서 보다 유의한 음(-)의 모멘텀 이익을 지지하는 증거를 보인다. 또 $\mathrm{W}-\mathrm{L}$ 무비용포트폴리오로부터의 음(-)의 모멘텀 이익은 패자포트폴리오의 강한 반전경향(하락 $\rightarrow$ 상승)에 의한 양 $(+)$ 의 투자성과에 크게 기인한다. 한편, 모멘텀 효과와 동일한 검증과정 하에서 단기반전현상에 대한 $\mathrm{W}-\mathrm{L}$ 무비용포트폴리오는 역시 높은 거래량 회전율 주식집단에서 유의한 음(-)의 투자성과를 보인다. 이는 한국 주식시장에 있어서 Jegadeesh (1990)의 단기반전현상의 존재를 지지하는 증거이고, 또한 본 연구에서 이용한 모멘텀 효과의 검증방법에 대한 신뢰성을 보여주는 것이다.

이제, <표 3>의 검증결과를 과거기간과 미래기간으로 구분하여 구체적으로 살펴본다. 먼저, 과거기간 분석결과를 보면, 형성기간이 길어질수록( 3 개월 $\rightarrow 12$ 개월) 승자포트폴리오의 초과 수익률은 증가 $($ 높은 거래량 회전율 집단 $31.02 \% \rightarrow 88.93 \%$; 낮은 거래량 회전율 집단 $18.51 \%$

9) 본 연구는 모멘텀 효과의 검증방법에 대한 신뢰성 확보를 위하여 과거기간 1 개월에 대해 동일하게 모멘텀 포트폴리오를 구성하고 미래기간의 투자성과를 조사한다. Jegadeesh(1990)의 단기반전효과를 반영한 투자전략은 패자포트폴리오를 매수하고 승자포트폴리오를 매도함으로써 미래기간에 양(+)의 투자성과를 실현한다. 한편, 본 연구의 모멘텀 효과의 검증방법을 동일하게 적용한다면, 승자포트 폴리오를 매수하고 패자포트폴리오를 매도하기 때문에 미래기간에 음(-)의 투자성과를 기대할 수 있다. 모멘텀 효과와 단기반전 효과는 다른 특징을 갖는 현상이기 때문에 모멘텀 효과의 검증방법으로 부터 단기반전 효과의 증거를 확인하는 것은 본 연구에서 적용된 검증과정의 신뢰성을 확인할 수 있게 한다. 


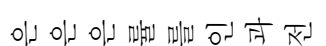

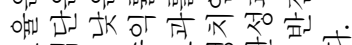

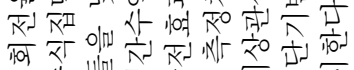

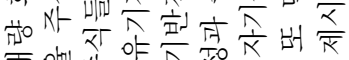

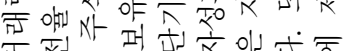

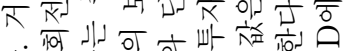

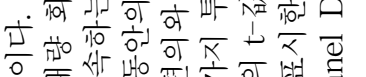

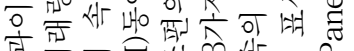

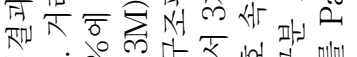
रो

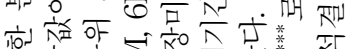

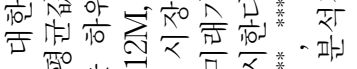

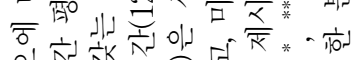

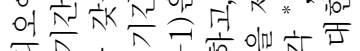

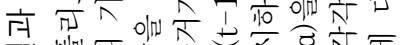

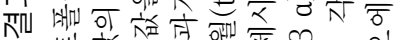

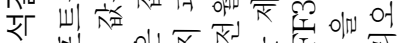

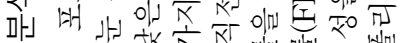
of $\begin{aligned} & f \\ & \text { के }\end{aligned}$

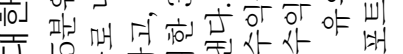

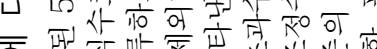
б 所

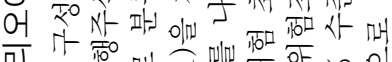
ज

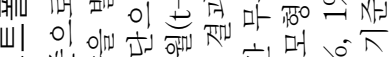

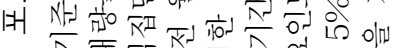

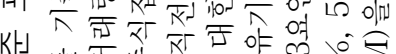

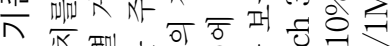

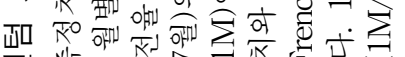

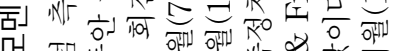
머 西以 Ho

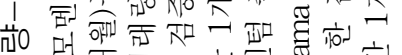

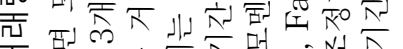
त

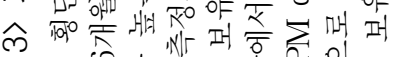

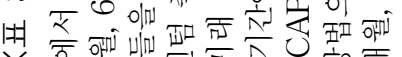
담

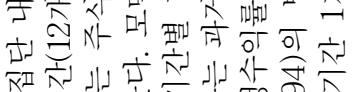

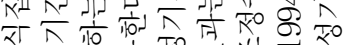

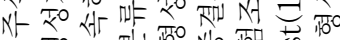

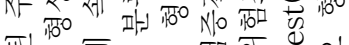

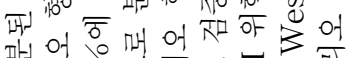

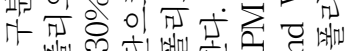
다 Hil

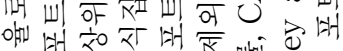

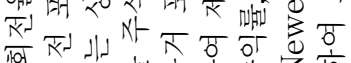

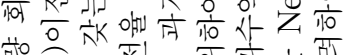
तु०

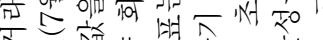

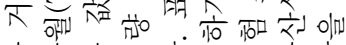
ل小

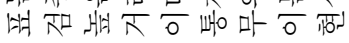

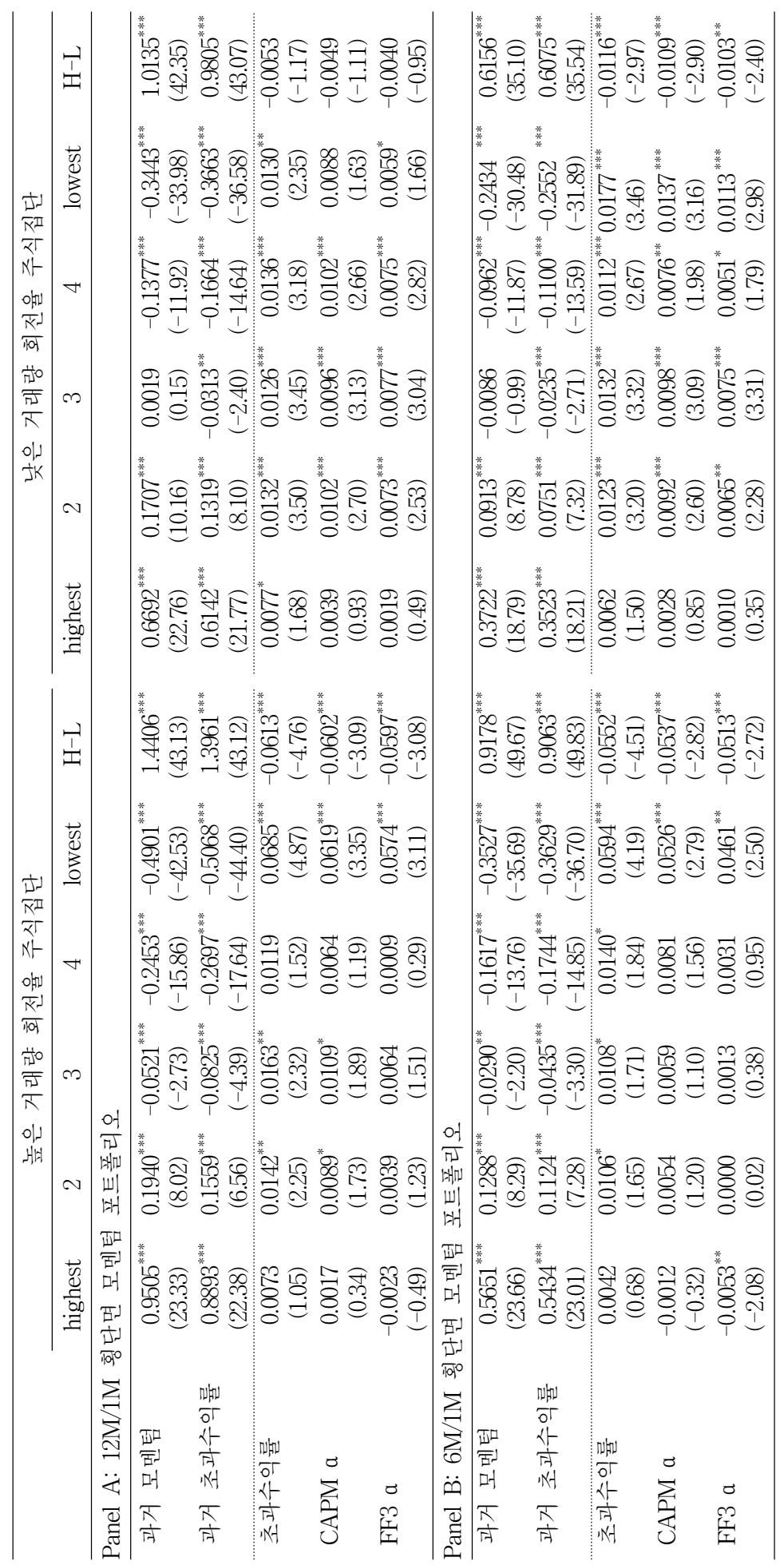




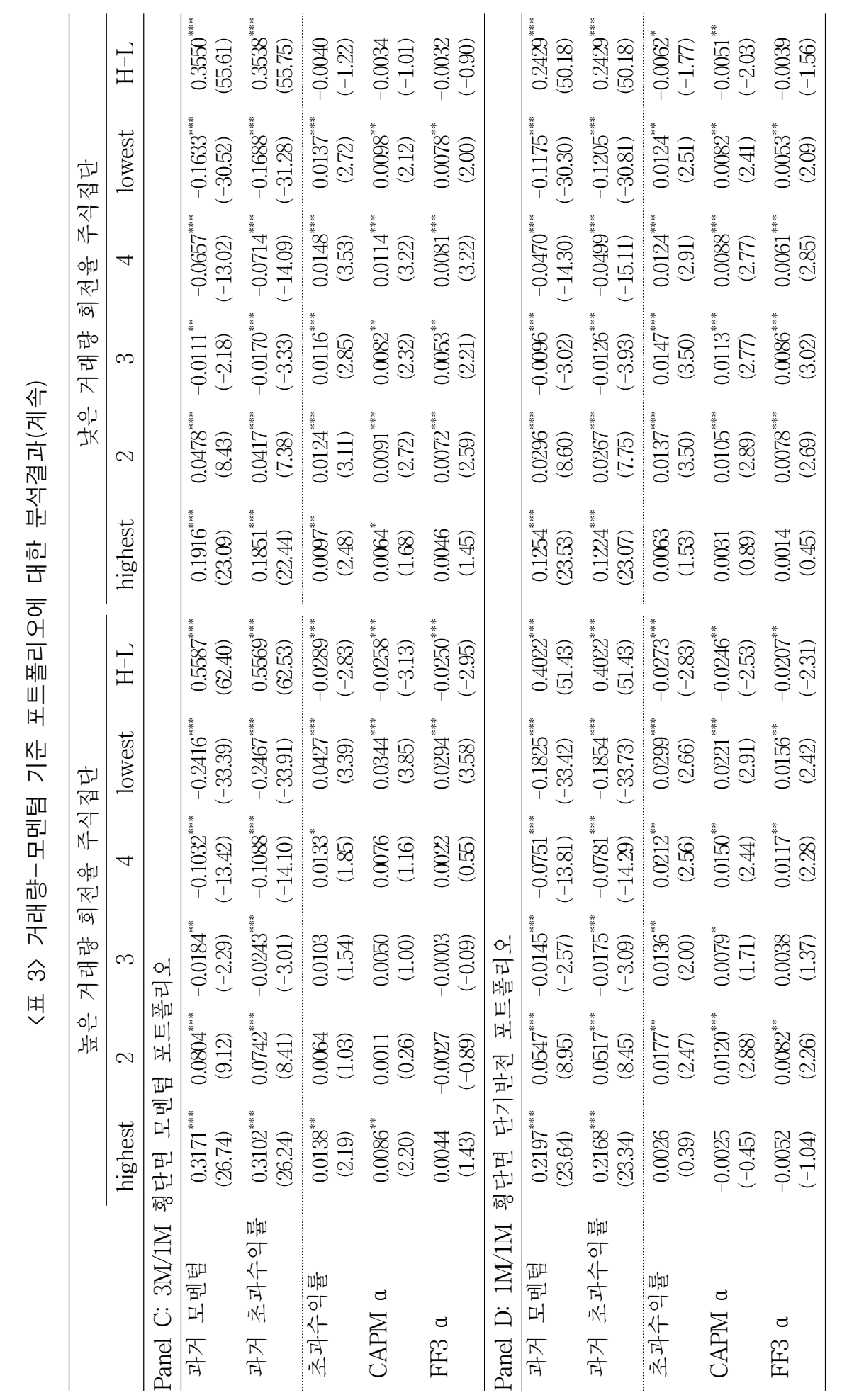


한국증권학회지 제49권 4호 (2020)

$\rightarrow 61.42 \%)$ 하고, 패자포트폴리오의 초과수익률은 감소 $(-24.67 \% \rightarrow-50.68 \% ;-16.88 \% \rightarrow$ -36.63\%)한다. 거래량 회전율에 따른 주식집단 비교에서, 높은 거래량 회전율 주식집단이 낮은 거래량 회전율 주식집단에 비교하여 높은 투자성과를 갖는다. 승자(패자)포트폴리오에 있어서, 높은 거래량 회전율 주식집단은 낮은 거래량 회전율 주식집단에 비교하여 형성기간 12 개월에 1.45 배(1.38배), 6 개월에 1.54 배(1.42배), 3 개월에 1.68 배(1.46배)의 높은 투자성과를 갖는다. 즉, 낮은 투자자 관심을 갖는 주식집단(낮은 거래량 회전율 주식집단)에 비교하여 높은 관심을 갖는 주식집단(높은 거래량 회전율 주식집단)에서 보다 큰 주가반응이 나타난다. 다음으로 미래기간에 대한 결과를 살펴본다. 높은 거래량 회전율 주식집단의 $\mathrm{W}-\mathrm{L}$ 무비용포트폴리오는 형성기간에 관계없이 3 가지 투자성과 측정치 모두가 유의한 음(-)의 값을 갖지만, 낮은 거래량 회전율 주식집단은 형성기간 6 개월의 투자성과를 제외하고 모두 비유의한 값을 갖는다. 그리고 거래량 회전율 구분에 관계없이, 승자포트폴리오는 대부분 비유의한 양( $(+)$ 의 투자성과를 보이고, 패자포트폴리오는 모두 유의한 양 $(+)$ 의 투자성과를 보인다. 과거 형성기간에서 미래 보유기간 으로의 투자성과 변화패턴을 살펴보면, 승자포트폴리오는 과거 형성기간의 초과수익률에 비교하여 미래 보유기간의 초과수익률은 급격히 감소하는 반전패턴을 보인다. 즉, 월평균 초과수익률의 관점에서, 승자포트폴리오의 초과수익률은 12 개월의 $5.96 \% \rightarrow 0.73 \%, 6$ 개월의 $9.07 \% \rightarrow 0.42 \%, 3$ 개월의 $14.46 \% \rightarrow 1.38 \%$ 로 급격히 하락한다. 한편, 패자포트폴리오는 과거 형성기간의 초과수익률에 비교하여 미래 보유기간의 초과수익률이 급격히 증가하는 반전패턴을 보인다. 즉, 월평균 초과수익률의 관점에서, 패자포트폴리오의 초과수익률은 12 개월의 $-6.22 \%$ $\rightarrow 6.85 \%, 6$ 개월의 $-8.62 \% \rightarrow 5.94 \%, 3$ 개월의 $-13.21 \% \rightarrow 4.27 \%$ 로 급격히 상승한다. 결국, $\mathrm{W}-\mathrm{L}$ 무비용포트폴리오의 월평균 초과수익률은 12 개월의 $8.27 \% \rightarrow-6.13 \%, 6$ 개월의 $13.77 \%$ $\rightarrow-5.52 \%, 3$ 개월의 $24.78 \% \rightarrow-2.89 \%$ 로 하락폭이 급격히 커지는 모습을 보인다. 이러한 결과는 한국 주식시장에서 과거기간에 투자자들의 높은 관심으로부터 낙관적인 과잉반응을 경험한 승자포트폴리오와 비관적인 과잉반응을 경험한 패자포트폴리오가 미래 보유기간에 빠른 시장 조정과정에 의하여 그 투자성과가 반전하는 패턴을 보임을 추론케 한다.

높은 거래량 회전율 주식집단 내에서 승자와 패자 포트폴리오의 초과수익률이 과거기간에서 미래기간에 걸쳐 반전하는 모습은 <그림 $1>$ 에서 분명하게 확인된다. <그림 1 >은 검증기간 (2000.07 2019.06)에서 12M/1M 모멘텀 투자전략으로부터 관찰된 228개 하위기간에 대한 승자/패자 포트폴리오의 과거기간과 미래기간의 초과수익률 분포를 나타낸 것이다.

$<$ 그림 1>을 보면 패자포트폴리오의 과거기간 투자성과 분포는 가장 왼쪽에 위치하나, 미래기간의 투자성과는 오른쪽으로 분명하게 이동한 모습을 확인할 수 있다. 반면에 승자포트 폴리오의 과거기간 투자성과 분포는 가장 오른쪽에 위치하며, 미래기간에는 왼쪽으로 이동한 모습을 확인할 수 있다. 즉, 시간의 흐름에 따라 패자포트폴리오의 성과는 상승하는 모습을 보이지만 승자포트폴리오는 하락하는 모습을 보인다. 한편, <표 $4>$ 에는 하위기간에서 실현된 승자포트폴리오와 패자포트폴리오의 투자성과가 계절적인 영향을 받는지를 분석한 결과를 나타 내었다. 계절성은 1 월과 나머지 월( 2 월 12 월)로 구분하여 투자성과를 분리하고, 각각에 대한 승자포트폴리오, 패자포트폴리오, $\mathrm{W}-\mathrm{L}$ 무비용포트폴리오의 투자성과를 제시한다. 
Investor Attention, Market Dynamics, and Momentum in the Korean Stock Market

〈그림 1〉승자포트폴리오와 패자포트폴리오의 투자성과 분포 비교

그림은 높은 거래량 회전율 주식집단 내에서 2000년 7월부터 2019년 6월까지의 검증기간 동안에 확인된 승자포트폴리오와 패자포트폴리오의 과거기간(포트폴리오 형성기간) 초과수익률과 미래 보유기간 초과 수익률을 커널추정법(kernal estimation)을 이용하여 도출한 빈도분포를 나타낸다. 그림에서 승자포트

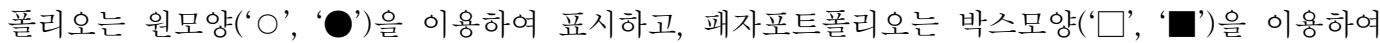
표시한다. 그리고 승자포트폴리오와 패자포트폴리오의 각 초과수익률에 있어서 과거기간('', ' $\square$ ')과 미래기간('O', ' $\square$ ')을 구분한다.

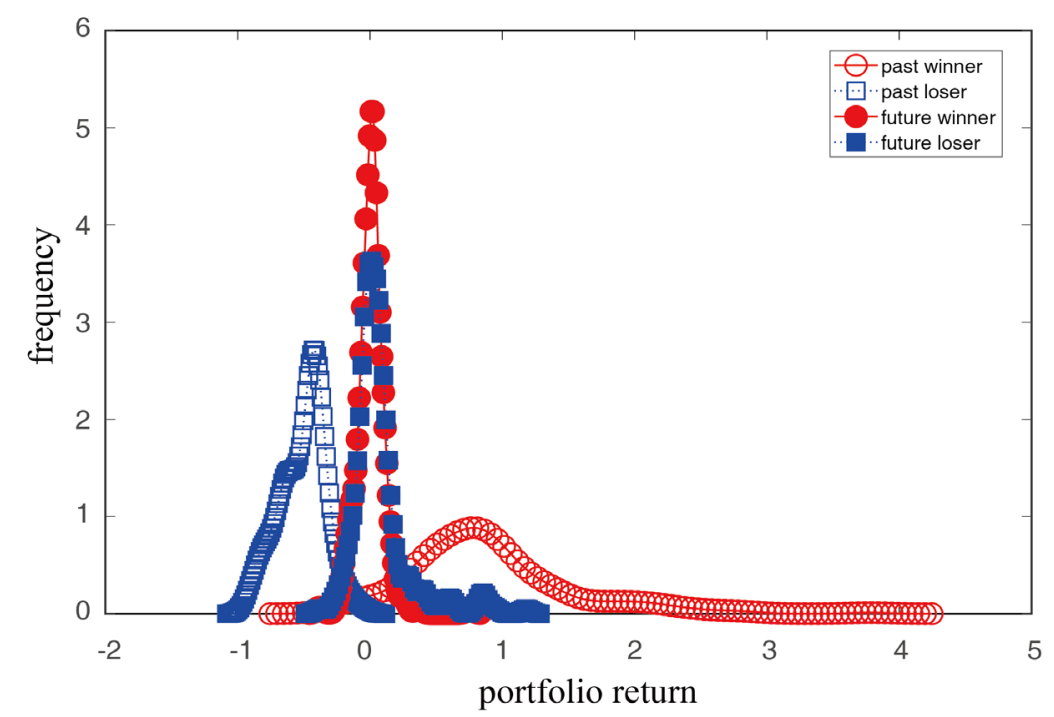

〈표 4〉승자포트폴리오와 패자포트폴리오에 대한 계절성 영향

표는 계절성(1월과 2 12월)이 승자포트폴리오와 패자포트폴리오의 성과에 미치는 영향을 보고한다. 모멘텀 측정치는 검증월(7월)의 직전 월(t-1)을 제외한 3 가지 과거기간(12M, $6 \mathrm{M}, 3 \mathrm{M})$ 동안의 보유기간 수익률이며, 표의 보고수치는 각 포트폴리오 형성기간별로 미래 1 개월(1M)의 초과수익률이다. 직전월 (t-1)은 시장미시구조편의와 단기반전효과를 통제하기 위하여 제외한다. 괄호 속의 $\mathrm{t}-$ 값은 자기상관성과 이분산성을 Newey and West(1994)의 표준오차로 조정한 값이다. $10 \%, 5 \%, 1 \%$ 수준의 유의성을 각각 *, **, ***로 구분 표시한다.

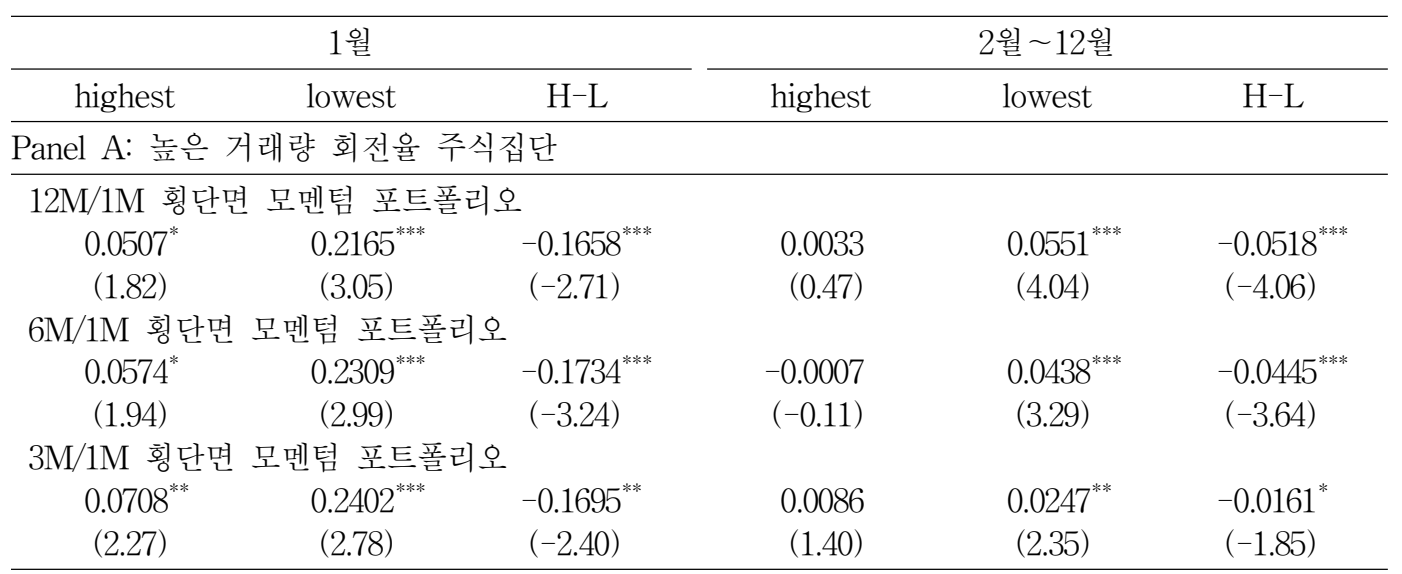


한국증권학회지 제49권 4호 (2020)

〈표 4〉 승자포트폴리오와 패자포트폴리오에 대한 계절성 영향(계속)

\begin{tabular}{|c|c|c|c|c|c|}
\hline \multicolumn{3}{|c|}{ 1월 } & \multicolumn{3}{|c|}{ 2월 12월 } \\
\hline highest & lowest & $\mathrm{H}-\mathrm{L}$ & highest & lowest & $\mathrm{H}-\mathrm{L}$ \\
\hline \multicolumn{6}{|c|}{ Panel B: 낮은 거래량 회전율 주식집단 } \\
\hline \multicolumn{6}{|c|}{ 12M/1M 횡단면 모멘텀 포트폴리오 } \\
\hline $\begin{array}{r}0.0219 \\
(1.41)\end{array}$ & $\begin{array}{c}0.0437^{*} \\
(1.66)\end{array}$ & $\begin{array}{r}-0.0218 \\
(-1.18)\end{array}$ & $\begin{array}{r}0.0064 \\
(1.33)\end{array}$ & $\begin{array}{c}0.0102^{*} \\
(1.84)\end{array}$ & $\begin{array}{r}-0.0038 \\
(-0.81)\end{array}$ \\
\hline \multicolumn{6}{|c|}{$6 \mathrm{M} / 1 \mathrm{M}$ 횡단면 모멘텀 포트폴리오 } \\
\hline $\begin{array}{r}0.0074 \\
(0.56)\end{array}$ & $\begin{array}{c}0.0613^{\text {** }} \\
(2.21)\end{array}$ & $\begin{array}{c}-0.0539^{* * *} \\
(-2.94)\end{array}$ & $\begin{array}{r}0.0061 \\
(1.40)\end{array}$ & $\begin{array}{c}0.0138^{* * *} \\
(2.79)\end{array}$ & $\begin{array}{c}-0.0077^{* *} \\
(-2.02)\end{array}$ \\
\hline \multicolumn{6}{|c|}{ 3M/1M 횡단면 모멘텀 포트폴리오 } \\
\hline $\begin{array}{r}0.0167 \\
(1.10)\end{array}$ & $\begin{array}{c}0.03866^{* *} \\
(1.99)\end{array}$ & $\begin{array}{c}-0.0219^{* *} \\
(-2.55)\end{array}$ & $\begin{array}{c}0.0091^{* *} \\
(2.24)\end{array}$ & $\begin{array}{c}0.0115^{* *} \\
(2.20)\end{array}$ & $\begin{array}{r}-0.0024 \\
(-0.69)\end{array}$ \\
\hline
\end{tabular}

표에 의하면, 높은 거래량 회전율 주식집단에서, 승자포트폴리오와 패자포트폴리오 모두는 2 월 12 월에 비교하여 1 월에서 보다 높은 투자성과를 실현한다. 패자포트폴리오는 1 월과 나머지 월 모두에서 유의한 투자성과를 실현하며, 그 크기는 1월이 나머지 월보다 3.93배(12M/1M) $\sim 9.72$ 배(3M/1M)의 높은 값을 갖는다. 승자포트폴리오는 1월에 통계적으로 유의한 양(+)의 성과를 갖지만, 나머지 월에서는 유의성을 확인하기 어렵다. 따라서 $\mathrm{W}-\mathrm{L}$ 무비용포트폴리오의 투자성과 역시 1 월에 유의하고 보다 큰 음(-)의 값을 보인다. 낮은 거래량 회전율 주식집단의 경우 이러한 특성이 크게 약화되어 $\mathrm{W}-\mathrm{L}$ 무비용포트폴리오가 음(-)의 값을 가지나 그 유의성과 크기가 현저히 줄어든 모습을 보인다.

\section{3 과잉반응 정도와 음(-)의 모멘텀 효과}

<표 3>에서 낮은 거래량 회전율 주식집단에 비하여 높은 거래량 회전율 주식집단의 $\mathrm{W}-\mathrm{L}$ 무비용포트폴리오의 미래기간 음(-)의 초과수익률은 최소 4.78 배(6M/1M)에서 최대 11.61 배 $(12 \mathrm{M} / 1 \mathrm{M})$ 의 큰 값을 갖는다. 승자포트폴리오의 미래기간 초과수익률은 높은 거래량 회전율 주식집단이 낮은 거래량 회전율 주식집단에 비교하여 0.67 배 $(6 \mathrm{M} / 1 \mathrm{M}) \sim 1.42$ 배 $(3 \mathrm{M} / 1 \mathrm{M})$ 의 값을 가지나, 패자포트폴리오의 경우 3.10 배 $(3 \mathrm{M} / 1 \mathrm{M}) \sim 5.27$ 배 $(12 \mathrm{M} / 1 \mathrm{M})$ 로 매우 높은 값을 갖는다. 이는 높은 거래량 회전율 주식집단 내의 패자포트폴리오에서 나타나는 가격반전이 모멘텀 효과에 큰 영향을 미침을 의미한다. 이러한 결과는 주가 변동에 대한 투자자의 과잉반응 정도의 차이에 기인할 수 있다.10)

10) <표 3>을 보면 과거기간의 초과수익률이 유사한 경우에도 높은 거래량 회전율 주식집단이 낮은 거래량 회전율 주식집단에 비하여 미래기간 초과수익률이 보다 높음을 확인할 수 있다. 예를 들어, 과거기간에서 낮은 거래량 회전율 주식집단의 형성기간 6 개월에 대한 5 분위 포트폴리오의 초과수익률 범 위는 $35.23 \%$ - $25.52 \%$ 이고, 유사한 수준의 초과수익률 범위를 갖는 높은 거래량 회전율 주식 집단의 형성기간 3 개월이다(31.02\% - 24.67\%). 이들의 미래기간 초과수익률을 비교하면, 높은 거래량 회전율 주식집단 $(1.38 \% \sim 4.27 \%)$ 이 낮은 거래량 회전율 주식집단 $(0.62 \% \sim 1.77 \%)$ 에 비해 
Investor Attention, Market Dynamics, and Momentum in the Korean Stock Market

본 연구에서는 음(-)의 모멘텀 이익을 보여주는 <표 3>의 결과에 대한 가능한 설명을 투자자의 높은 관심에 따른 승자포트폴리오와 패자포트폴리오의 과잉반응 정도에 기인한 반전특성, 그리고 이로 인한 승자포트폴리오의 높은 매도경향과 패자포트폴리오의 낮은 매도경향(높은 손실회피 경향)에서 찾는다. 두 가지 가능한 설명에 대한 증거로 첫째, 승자/패자 포트폴리오의 과잉반응 정도와 미래기간 투자성과 간의 관계를 조사한 <표 5>의 결과, 둘째, 승자/패자 포트폴리오의 매도경향 정도 비교를 처분효과(Shefrin and Statman, 1985)를 근거로 분석한 <표 6>의 결과로 구분 제시한다.

\subsection{1 과잉반응 정도와 모멘텀 효과}

먼저 과거기간 승자포트폴리오와 패자포트폴리오의 과잉반응 정도에 따른 미래기간 투자성과의 차이를 <표 5>에서 살펴본다. 과거기간의 과잉반응 정도는 Lo and MacKinlay(1990)의 방법과 유사하게, 승자/패자 포트폴리오 내에서 보다 극단적인 이익/손실을 경험한 주식들로 구분한다. 즉, 승자포트폴리오를 구성하는 모든 주식들의 모멘텀 측정치의 평균 $\left(\overline{M O M}^{(W)}=\frac{1}{N_{W}} \sum_{j=1}^{N_{W}} M O M_{j}^{(W)}\right)$ 보다 높은 모멘텀 측정치를 갖는 주식들 $\left(M O M_{j}^{(W)}>\overline{M O M}^{(W)}\right)$ 은 낮은 측정치를 갖는 주식들 $\left(M O M_{j}^{(W)} \leqq \overline{M O M}^{(W)}\right)$ 보다 상대적으로 높은 과잉반응을 경험한 것으로 판단한다. 패자포트폴리오를 구성하는 주식들은, 모멘텀 측정치의 평균 $\left(\overline{M O M}^{(L)}=\frac{1}{N_{L}} \sum_{j=1}^{N_{L}} M O M_{j}^{(L)}\right)$ 보다 낮은 측정치를 갖는 주식들 $\left(M O M_{j}^{(L)}<\overline{M O M}^{(L)}\right)$ 은 높은 측정치를 갖는 주식들 $\left(M O M_{j}^{(L)} \geqq \overline{M O M}^{(L)}\right)$ 보다 상대적으로 높은 과잉반응을 경험한 것으로 볼 수 있다. 이런 분류방법에 따라 구분된 두 주식집단 별 승자와 패자 포트폴리오 내의 높은 과잉반응 집단과 낮은 과잉반응 집단에 대한 과거기간 성과와 미래 보유기간성과를 <표 5>에 제시한다.

표에 의하면, 높은 과잉반응 집단이 낮은 과잉반응 집단에 비해 거래량회전율이나 승자/패자 여부에 관계없이 미래기간에서 성과가 보다 크게 반전하는 패턴을 보인다. Panel A에서, 승자포트폴리오를 구성하는 주식들의 경우 보다 극단적인 이익을 경험한 높은 과잉반응 집단의 과거기간과 미래기간의 성과차이 $(-1.40 \sim-0.44)$ 는 낮은 과잉반응 집단의 성과차이 $(-0.19$ $-0.50)$ 보다 2.32배 2.79 배 크다. 패자포트폴리오를 구성하는 주식들의 경우 보다 극단적 손실을 경험한 높은 과잉반응 집단의 과거기간과 미래기간의 성과차이(0.39 0.80)는 낮은 과잉반응 집단의 성과차이(0.21 0.41) 보다 1.85배 2.07배 크다. 이러한 특성은 Panel B.의 낮은 거래량 회전율 주식집단에서도 유사하게 나타나지만, 높은 거래량 회전율 주식집단(Panel A)에 비교하여 낮은 과잉반응의 증거를 보인다. <표 $5>$ 의 높은 거래량 회전율 주식집단(Panel A)의 결과 중에서 $12 \mathrm{M} / 1 \mathrm{M}$ 모멘텀 투자전략의 승자/패자 포트폴리오를 구성하는 주식들을 높은 과잉반응 집단과 낮은 과잉반응 집단으로 구분한 후에, 두 집단의 과거기간과 미래기간의 투자성과 분포를 <그림 2>에 나타내었다. <그림 2>는 승자 또는 패자에 관계없이 높은 과잉반응 집단에서 큰 폭의 가격반전이 나타남을 잘 보여준다.

보다 큰 범위에서 변동한다. 즉, 과거기간의 투자성과가 유사하다 할지라도, 투자자의 낮은 관심을 받는 주식집단 보다는 투자자의 높은 관심을 받는 주식집단에서 과잉반응에 따라 주가가 크게 변동할 가능성이 높고 이는 보다 큰 반전으로 이어질 수 있다. 
한국증권학회지 제49권 4호 (2020)

$<$ 표 5>와 <그림 2>의 결과는 승자포트폴리오의 반전패턴(상승 $\rightarrow$ 하락)와 패자포트폴리오의 반전패턴(하락 $\rightarrow$ 상승)이 과거기간의 이익/손실에 대한 투자자들의 과잉반응 정도에 기인할 수 있음을 실증적으로 보여준다. 한편, 통계적 유의성을 보면, 승자포트폴리오 내에서 과잉반응 정도에 따라 구분된 2 가지 주식집단의 미래기간의 성과는 대부분 비유의한 양(+)의 값을 보이지만,

〈표 5〉승자포트폴리오와 패자포트폴리오의 과잉반응정도에 따른 투자성과 비교 표는 승자포트폴리오와 패자포트폴리오 각각의 과거기간 과잉반응정도에 따른 미래 보유기간 투자성과를 보고한다. 과잉반응 정도는 과거기간 모멘텀 측정치의 평균값 $(\overline{M O M})$ 을 이용한다. 즉, 승자포트폴리오를 구성하는 주식들에 있어서, 모든 주식들의 평균값 보다 높은 모멘텀 측정치를 갖는 주식 $\left(M O M_{j}>\overline{M O M}\right)$ 을 높은 과잉반응 주식으로, 낮은 모멘텀 측정치를 갖는 주식 $\left(M O M_{j} \leqq \overline{M O M}\right)$ 을 낮은 과잉반응 주식으로 구분한다. 패자포트폴리오를 구성하는 주식들은 평균값 보다 낮은 모멘텀 측정치를 갖는 주식 $\left(M O M_{j}<\overline{M O M}\right)$ 을 높은 과잉반응 주식으로, 낮은 모멘텀 측정치를 갖는 주식 $\left(M O M_{j} \geqq \overline{M O M}\right)$ 을 낮은 과잉반응 주식으로 구분한다. 모멘텀 측정치는 검증월(7월)의 직전 월(t-1)을 제외한 3 가지 과거기간 $(12 \mathrm{M}, 6 \mathrm{M}, 3 \mathrm{M})$ 동안의 보유기간수익률이며 포트폴리오 형성기간별 미래 보유기간 1 개월(1M)에 대한 결과를 보고한다. 직전월 (t-1)은 시장미시구조편의와 단기반전효과를 통제하기 위하여 제외한다. 검증결과는 각 하위기간에서 구분된 주식집단에서 확인된 과거기간 초과수익률과 미래기간 초과수익률 각각의 평균 값을 제시한다. 괄호 안의 t-값은 자기상관성과 이분산성을 Newey and West(1994)의 방법으로 통제한 값이며, $10 \%$, $5 \%, 1 \%$ 유의수준을 각기 * ${ }^{* *},{ }^{* * *}$ 로 구분 표시한다.

\begin{tabular}{|c|c|c|c|c|c|c|}
\hline \multicolumn{3}{|c|}{ 과거기간 승자포트폴리오 } & \multicolumn{4}{|c|}{ 과거기간 패자포트폴리오 } \\
\hline$M O M_{j}^{(W)}>\overline{M O M}^{(W)}$ & \multicolumn{2}{|c|}{$M O M_{j}^{(W)} \leqq \overline{M O M}^{(W)}$} & \multicolumn{2}{|c|}{$M O M_{j}^{(L)}<\overline{M O M}^{(L)}$} & \multicolumn{2}{|c|}{$M O M_{j}^{(L)} \geqq \overline{M O M}^{(L)}$} \\
\hline 과거성과 미래성과 & 과거성과 & 미래성과 & 과거성과 & 미래성과 & 과거성과 & 미래성과 \\
\hline \multicolumn{7}{|c|}{ Panel A: 높은 거래량 회전율 주식집단 } \\
\hline \multicolumn{7}{|c|}{ 12M/1M 횡단면 모멘텀 포트폴리오 } \\
\hline $\begin{array}{lr}1.4030^{* * *} & -0.0027 \\
(25.44) & (-0.30)\end{array}$ & $\begin{array}{l}0.5157^{* * *} \\
(21.22)\end{array}$ & $\begin{array}{r}0.0145 \\
(1.43)\end{array}$ & $\begin{array}{l}-0.6720^{* * *} \\
(-60.30)\end{array}$ & $\begin{array}{l}0.1286^{* * *} \\
(4.31)\end{array}$ & $\begin{array}{l}-0.3844^{* * *} \\
(-50.74)\end{array}$ & $\begin{array}{l}0.0240^{* * *} \\
(2.69)\end{array}$ \\
\hline \multicolumn{7}{|c|}{ 6M/1M 횡단면 모멘텀 포트폴리오 } \\
\hline $\begin{array}{ll}0.8507^{* * *} & -0.0061 \\
(25.72) & (-0.65)\end{array}$ & $\begin{array}{l}0.3239^{* * *} \\
(22.28)\end{array}$ & $\begin{array}{r}0.0115 \\
(1.42)\end{array}$ & $\begin{array}{l}-0.5020^{* * *} \\
(-44.21)\end{array}$ & $\begin{array}{l}0.1040^{* * * *} \\
(3.50)\end{array}$ & $\begin{array}{l}-0.2653^{* * *} \\
(-38.70)\end{array}$ & $\begin{array}{l}0.0280^{* *} \\
(2.46)\end{array}$ \\
\hline \multicolumn{7}{|c|}{ 3M/1M 횡단면 모멘텀 포트폴리오 } \\
\hline $\begin{array}{l}0.4600^{* * *} \\
(27.77)\end{array}$ & $\begin{array}{l}0.2013^{* * *} \\
(26.34)\end{array}$ & $\begin{array}{r}0.0110 \\
(1.32)\end{array}$ & $\begin{array}{l}-0.3373^{* * *} \\
(-40.85)\end{array}$ & $\begin{array}{l}0.0484^{* *} \\
(2.16)\end{array}$ & $\begin{array}{l}-0.1707^{* * *} \\
(-31.85)\end{array}$ & $\begin{array}{l}0.0378^{* * *} \\
(2.79)\end{array}$ \\
\hline \multicolumn{7}{|c|}{ Panel B: 낮은 거래량 회전율 주식집단 } \\
\hline \multicolumn{7}{|c|}{ 12M/1M 횡단면 모멘텀 포트폴리오 } \\
\hline $\begin{array}{l}1.0027^{* * *} \\
(26.93)\end{array}$ & $\begin{array}{l}0.3366^{* * *} \\
(21.74)\end{array}$ & $\begin{array}{r}0.0038 \\
(0.66)\end{array}$ & $\begin{array}{l}-0.4970^{* * *} \\
(-42.80)\end{array}$ & $\begin{array}{r}0.0136 \\
(1.24)\end{array}$ & $\begin{array}{l}-0.2678^{* * *} \\
(-35.19)\end{array}$ & $\begin{array}{l}0.0125^{* *} \\
(2.47)\end{array}$ \\
\hline \multicolumn{7}{|c|}{ 6M/1M 횡단면 모멘텀 포트폴리오 } \\
\hline $\begin{array}{l}0.6399^{* * *} \\
(19.29)\end{array}$ & $\begin{array}{l}0.1908^{* * *} \\
(22.90)\end{array}$ & $\begin{array}{r}0.0055 \\
(1.22)\end{array}$ & $\begin{array}{l}-0.3550^{* * *} \\
(-39.80)\end{array}$ & $\begin{array}{l}0.0206^{* *} \\
(2.36)\end{array}$ & $\begin{array}{l}-0.1685^{* * *} \\
(-30.28)\end{array}$ & $\begin{array}{l}0.0153^{* * *} \\
(2.58)\end{array}$ \\
\hline \multicolumn{7}{|c|}{$3 \mathrm{M} / 1 \mathrm{M}$ 횡단면 모멘텀 포트폴리오 } \\
\hline $\begin{array}{l}0.2990^{* * *} \\
(26.37)\end{array}$ & $\begin{array}{l}0.1066^{* * *} \\
(23.14)\end{array}$ & $\begin{array}{r}0.0065 \\
(1.37) \\
\end{array}$ & $\begin{array}{l}-0.2394^{* * *} \\
(-34.35)\end{array}$ & $\begin{array}{l}0.0193^{* *} \\
(2.03)\end{array}$ & $\begin{array}{l}-0.1155^{* * *} \\
(-34.59)\end{array}$ & $\begin{array}{c}0.0096^{*} \\
(1.82) \\
\end{array}$ \\
\hline
\end{tabular}


Investor Attention, Market Dynamics, and Momentum in the Korean Stock Market

패자포트폴리오 내에서의 두 집단은 모두 유의한 양(+)의 값을 갖는다. 즉, 패자포트폴리오에서 나타나는 반전패턴이 승자포트폴리오에서보다 더욱 강하며, 그 크기는 높은 과잉반응 집단에서 더욱 크게 나타난다. 이는 W-L 무비용포트폴리오에서 확인된 음(-)의 모멘텀 이익이 패자포트 폴리오에서 나타나는 성과반전에 기인하며, 그 음 $(-)$ 의 크기는 투자자의 과잉반응 정도가 높을수록 크게 나타남을 의미한다.

〈그림 2〉 승자포트폴리오와 패자포트폴리오의 과잉반응정도에 따른 투자성과 분포 비교 그림은 2000년 7월부터 2019년 6월까지의 검증기간 동안에 각 하위기간별로 승자포트폴리오와 패자포트 폴리오 각각을 구성하는 주식들을 높은 과잉반응 집단과 낮은 과잉반응 집단으로 구분하고 두 집단에 대해 과거기간 초과수익률과 미래기간 초과수익의 분포를 box-plot방법을 이용하여 비교한 것이다. 그림에서, $\mathrm{X}$ 축은 과거기간과 미래기간의 구분이고, $\mathrm{Y}$ 축은 보유기간 초과수익률을 나타낸다. 그림 내에서 왼쪽 분포는 과거기간을 오른쪽 분포는 미래기간을 나타낸다. 그림들 중에서, 승자포트폴리오에 대한 것은 <그림 (a)>와 <그림 (b)>이고, 패자포트폴리오에 대한 것은 <그림 (c) > 와 <그림 (d) > 이다. 높은 과잉반응정도를 갖는 주식집단은 <그림 $(\mathrm{a})>$ 와 <그림 $(\mathrm{c})>$ 이고, 낮은 과잉반응정도를 갖는 주식집단은 $<$ 그림 (b)>와 <그림 $(\mathrm{d})>$ 이다.

(a)

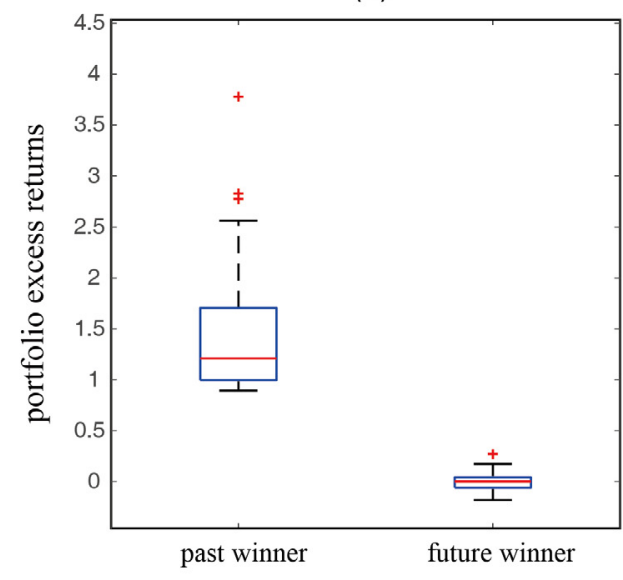

(c)

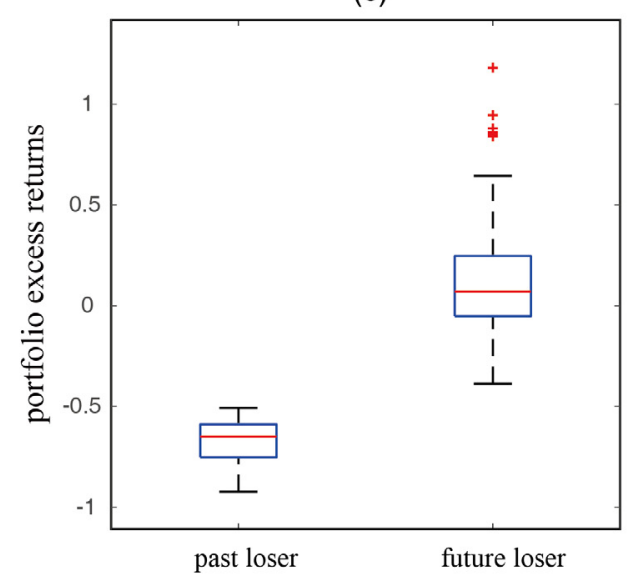

(b)

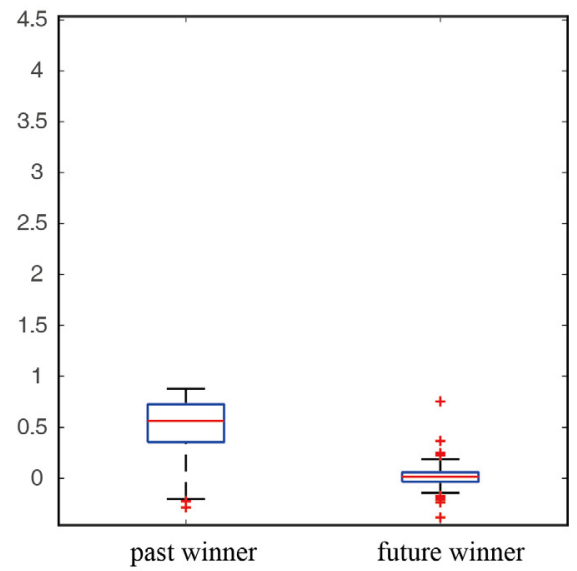

(d)

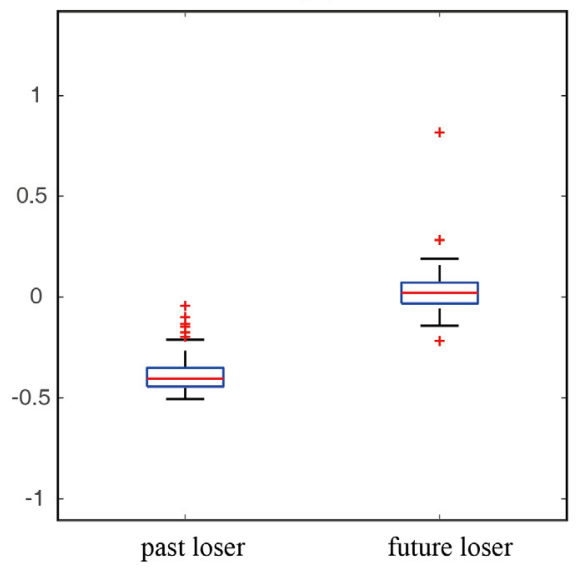


한국증권학회지 제49권 4호 (2020)

\subsection{2 매도경향 정도와 모멘텀 효과}

다음으로 Shefrin and Statman(1985)의 처분효과에 근거하여 승자/패자 포트폴리오의 매도경향 정도에 따른 차이를 분석하고 그 결과를 <표 6>에 제시한다. Grinblatt and Han (2005)은 처분효과가 미국 주식시장에서 관찰되는 모멘텀 효과를 설명할 수 있는 중요 원인이라고 주장한다. Statman et al.(2006)은 처분효과는 Kahneman and Tversky(1979)에서 보인 전망이론(prospect theory)에 승자포트폴리오에 대한 자랑(pride)과 패자포트폴리오에 대한 후회(regret)가 결합된 것이기 때문에 포트폴리오를 구성하는 주식들에 대한 투자자의 관심을 나타내는 것이라고 주장한다. 본 연구는 거래량-모멘텀 포트폴리오의 실증 구조에서 처분효과의 계량적 측정치로 Grinblatt and $\operatorname{Han}(2005)$ 이 제안한 COG(capital overhang gain) 측정치를 이용한다.

$$
\begin{aligned}
& C O G_{t}=\frac{P_{t}-R P_{t}}{P_{t}} \\
& R P_{t}=\frac{1}{k} \sum_{n=1}^{T}\left[V_{t-n} \Pi_{\tau=1}^{n-1}\left(1-V_{t-n+\tau}\right)\right] P_{t-n}
\end{aligned}
$$

식 (1)에서 $R P_{t}$ 는 준거가격(reference price)을 나타내다. 준거가격은 모멘텀 측정치를 산출하는 각 하위기간의 과거기간 $(n=1(=t-2), 2(=t-3), \ldots T(=t-12))$ 에서 월별 주식가격 $\left(P_{t}\right)$ 과 월별 거래량 회전율 $\left(V_{t}\right)$ 를 이용한다. 거래량 회전율은 가중치의 역할을 한다.11) 그리고 $k$ 는 가중치의 합이 1 이 되도록 조정하는 상수이다. 식 (1)로 계산되는 처분효과 측정치 $(C O G)$ 의 값이 크면 클수록 매도경향이 높다는 것을 의미하고, 작으면 작을수록 손실회피경향이 높아서 매도경향이 낮다는 것을 의미한다. 검증기간(2000.07 2019.06) 동안 승자포트폴리와 패자포트 폴리오 각각에 대하여 산출된 처분효과 측정치는 <표 6>에 제시한다.

<표 6>을 보면 거래량 회전율에 관계없이, 승자포트폴리오는 유의한 양(+)의 처분효과 측정치를 갖고 패자포트폴리오는 유의한 음(-)의 측정치를 갖는다. 즉, 과거기간에 높은 성과를 실현한 승자포트폴리오의 구성주식들에 대해 투자자들은 높은 매도경향을 갖지만, 패자포트 폴리오의 구성주식들에 대해서는 투자자들이 높은 손실회피경향(낮은 매도경향)을 보인다. 그리고 절대값의 관점에서 측정치의 크기를 비교하면, 패자포트폴리오가 승자포트폴리오에 비하여 매우 큰 값을 갖는다. 이는 패자포트폴리오를 구성하는 주식들에 대한 손실회피경향의

11) 본 연구는 기본적으로 동일한 검증설계 하에서 처분효과와의 결합을 위하여, 월별 거래량을 발행주식수로 나눈 거래량 회전율을 이용한다. 하지만, <표 $1>$ 에서 확인할 수 있듯이 월별거래량은 해당 월의 일간 거래량을 합한 값이기 때문에 발행주식수 보다 큰 값을 가질 수 있다. 즉, 거래량 회전율은 1 보다 큰 값을 갖는다. 이러한 점은 월별 거래량 회전율을 포트폴리오를 구성하는 경우에 적용하는 것은 문제가 되지 않지만, 처분효과의 산출을 위해 식 (2)의 준거가격 산출을 위해 거래량 회전율을 가중치로 이용하는 경우엔, 산출식의 속성에 따라 음(-)의 값을 생성하는 문제점이 발생한다. 따라서 이러한 문제를 해결하기 위하여, 본 연구는 식 (2)에 적용할 거래량 회전율을 산출할 때, 거래량 회전율의 산출식에서 분자인 월별 거래량을 나누는 발행주식수에 과거기간 길이를 상수로 곱하여 구했다. 이를 통해 거래량 회전율이 1 보다 큰 값을 갖는 문제점을 해결할 수 있으며, 이는 모든 분석대상 주식에 동일하게 적용하였기 때문에 검증결과엔 영향을 미치진 않는다. 
Investor Attention, Market Dynamics, and Momentum in the Korean Stock Market

강도가 승자포트폴리오를 구성하는 주식들에 대한 매도경향보다 훨씬 높다는 것을 의미한다. 한편, 낮은 거래량 회전율의 주식집단 보다는 높은 거래량 회전율의 주식집단에서 보다 강한 처분효과의 증거를 보인다.

〈표 6〉승자포트폴리오와 패자포트폴리오의 처분효과 측정치(COG) 비교 표는 거래량 회전율로 구분된 주식집단 내에서 횡단면 모멘텀 포트폴리오에 대한 처분효과 측정치(capital gain overhang, $\mathrm{CGO}$ )를 보고한다. 처분효과 측정치는 Grinblatt and $\mathrm{Han}(2005)$ 에 근거하여 모멘텀 측정치의 과거기간(t-12 t-2)에서 거래량 회전율과 가격자료를 이용하여 식 (1)로 산출한 값이다. 과거 형성기간을 기준으로 $12 \mathrm{M} / 1 \mathrm{M}(\mathrm{Panel} \mathrm{A}), 6 \mathrm{M} / 1 \mathrm{M}(\mathrm{Panel} \mathrm{B}), 3 \mathrm{M} / 1 \mathrm{M}(\mathrm{Panel}$ C)의 3 가지 모멘텀 포트 폴리오에 대한 결과를 구분 제시한다. 괄호 속의 $\mathrm{t}$-통계량은 자기상관성과 이분산성을 Newey and West(1994)의 방법으로 조정한 값이다. $10 \%, 5 \%, 1 \%$ 수준의 유의성을 ${ }^{*},{ }^{* *},{ }^{* * *}$ 로 구분 표시한다.

\begin{tabular}{|c|c|c|c|c|c|}
\hline \multicolumn{3}{|c|}{ 높은 거래량 회전율 주식집단 } & \multicolumn{3}{|c|}{ 낮은 거래량 회전율 주식집단 } \\
\hline highest & lowest & $\mathrm{H}-\mathrm{L}$ & highest & lowest & $\mathrm{H}-\mathrm{L}$ \\
\hline \multicolumn{6}{|c|}{ Panel A: $12 \mathrm{M} / 1 / \mathrm{M}$ 횡단면 모멘텀 포트폴리오 } \\
\hline $\begin{array}{c}0.1082^{* * *} \\
(2.40)\end{array}$ & $\begin{array}{l}-0.5192^{* * *} \\
(-10.34)\end{array}$ & $\begin{array}{l}0.6274^{* * *} \\
(9.49)\end{array}$ & $\begin{array}{c}0.1333^{* * *} \\
18.31\end{array}$ & $\begin{array}{l}-0.3740^{* * *} \\
(-15.69)\end{array}$ & $\begin{array}{l}0.5073^{* * * *} \\
(25.56)\end{array}$ \\
\hline \multicolumn{6}{|c|}{ Panel B: 6M/1/M 횡단면 모멘텀 포트폴리오 } \\
\hline $\begin{array}{l}0.1148^{* * *} \\
(8.85)\end{array}$ & $\begin{array}{l}-0.3233^{* * *} \\
(-7.16) \\
\end{array}$ & $\begin{array}{l}0.4382^{* * * *} \\
(9.00)\end{array}$ & $\begin{array}{l}0.0986^{* * *} \\
(19.17) \\
\end{array}$ & $\begin{array}{l}-0.1935^{* * *} \\
(-15.81) \\
\end{array}$ & $\begin{array}{l}0.2921^{\text {**** }} \\
(30.41)\end{array}$ \\
\hline \multicolumn{6}{|c|}{ Panel C: 3M/1/M 횡단면 모멘텀 포트폴리오 } \\
\hline $\begin{array}{l}0.1144^{* * *} \\
(22.32)\end{array}$ & $\begin{array}{l}-0.1649^{* * *} \\
(-17.87)\end{array}$ & $\begin{array}{l}0.2794^{* * *} \\
(41.51)\end{array}$ & $\begin{array}{l}0.0761^{* * *} \\
(20.35)\end{array}$ & $\begin{array}{l}-0.0984^{* * *} \\
(-16.73)\end{array}$ & $\begin{array}{l}0.1745^{\text {**** }} \\
(40.27)\end{array}$ \\
\hline
\end{tabular}

\subsection{3 보유기간의 확대와 모멘텀 효과의 추이}

<표 7>은 미래 보유기간을 1 개월에서 12 개월로 확대할 때 앞서 확인된 한국 주식시장에서의 음(-)의 모멘텀 이익이 어떻게 변화하는지를 분석한 결과를 제시한다. Daniel et al.(1998)의 과잉신뢰편의 가설에 근거한 선행연구에 의하면, 일반적으로 미래 보유기간을 1 개월에서 12 개월로 장기화함에 따라 모멘텀 포트폴리오로부터 관찰되는 투자성과는 단기적 지속패턴에서 장기적 반전패턴으로 변화한다는 것을 보여준다. 본 연구는 모멘텀 이익의 변화를 관찰하기 위하여 미래 보유기간은 1 개월, 3 개월, 6 개월, 12 개월의 4 가지로 설정하고, <표 $3>$ 과 동일한 검증과정을 수행한다. 하위기간의 기간이동은 보유기간이 겹치지 않는 방법을 채택한다. ${ }^{12}$

12) 본 연구는 기존연구에 근거하여 미래 보유기간을 최대 12 개월까지 설정한다. 이유는 다음과 같다. 첫째, Daniel et al.(1998)의 과잉반응편의 가설에 근거하여 투자자 심리를 반영한 모멘텀 관련 기존연구들에서, 대부분 미래보유기간 12 개월 전후로 초기 투자성과 패턴과 대조적인 반전패턴이 관찰된다. 둘째, Chui et al.(2000) 등의 연구에 근거하여 아시아 주식시장에서 양(+)의 모멘텀 이익이 관찰되지 않는 2000년 이후를 검증기간으로 설정하였다. 그리고 하위기간 이동방법으로 미래 보유기간이 겹치지 않는 방법을 채택함으로서 장단기의 보유기간 길이와 반비례하는 하위기간의 개수 문제점이 발생한다. 따라서 본 연구는 미래 보유기간 1 개월 12 개월에서 장단기의 영향을 조사한다. 물론, 본문에 보고하지는 않았지만 미래 보유기간을 24 개월과 36 개월에 적용한 경우에도 본문에서 언급하는 검증결과와 질적으로 다르지 않았다. 


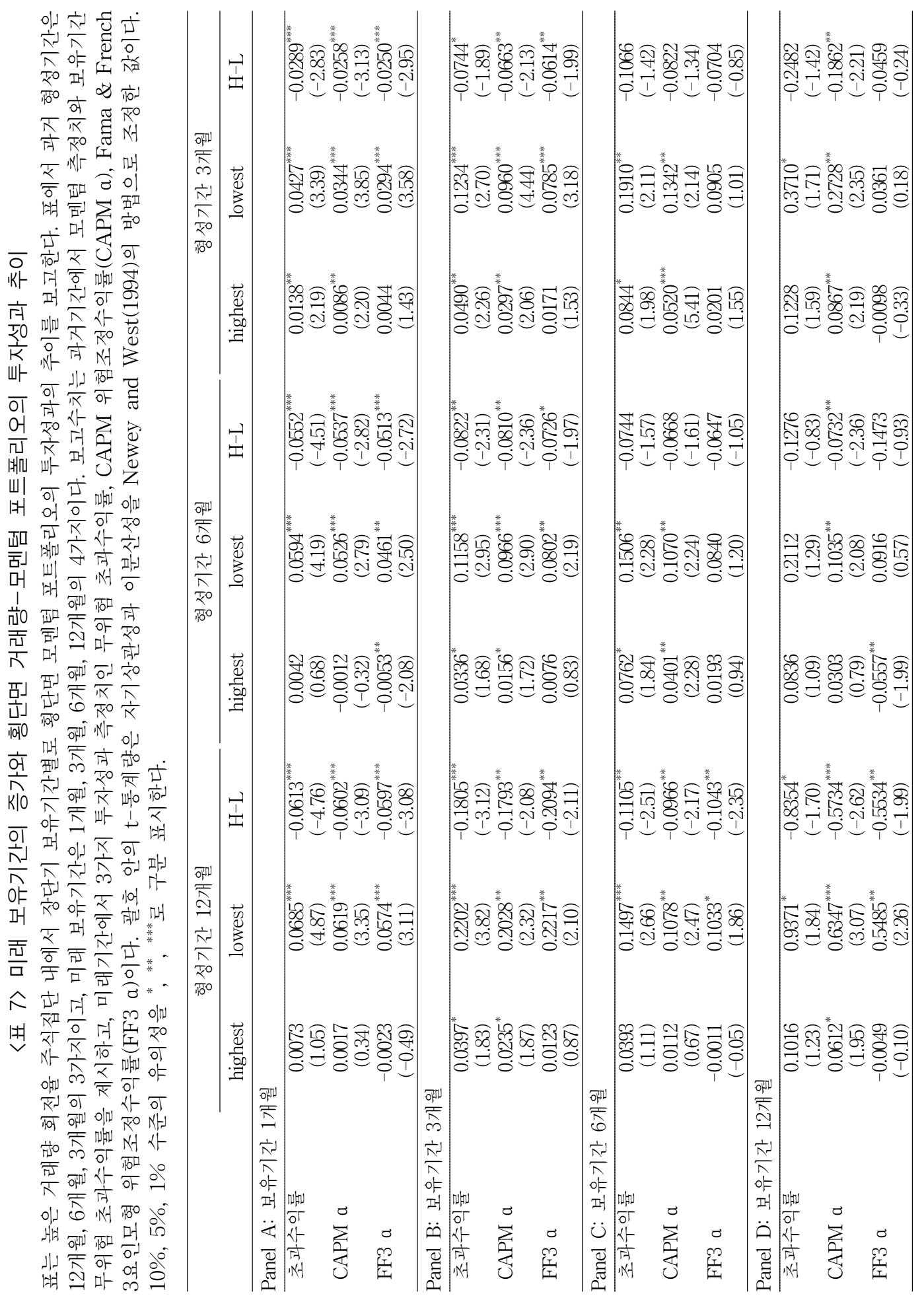


Investor Attention, Market Dynamics, and Momentum in the Korean Stock Market

<표 7>을 보면 패자포트폴리오는 미래 보유기간의 장기화에 관계없이 유의한 양(+)의 투자성과를 보이지만, 승자포트폴리오는 대부분 비유의한 투자성과를 보인다. 결국, W-L 무비용포트폴리오는 패자포트폴리오의 특성에 기인하여 유의한 음(-)의 모멘텀 이익을 보인다. 표의 결과를 포트폴리오 유형별로 살펴보면 다음과 같다. 첫째, $\mathrm{W}-\mathrm{L}$ 무비용포트폴리오이다. 높은 거래량 회전율 주식집단에서 $\mathrm{W}-\mathrm{L}$ 무비용포트폴리오의 투자성과는 미래 보유기간을 1 개월에서 12 개월로 늘림에 관계없이 모두 음 $(-)$ 의 값을 갖는다. 형성기간 12 개월의 모멘텀 전략은 지속적으로 유의한 음(-)의 모멘텀 이익을 보이고, 형성기간 6개월의 모멘텀 전략은 미래 보유기간 3 개월까지 유의한 음 $(-)$ 의 모멘텀 이익을 보이고, 이후 보유기간 12 개월에서 유의한 성과를 갖는다. 형성기간 3개월의 모멘텀 전략은 미래 보유기간 3개월까지 유의한 음(-)의 모멘텀 이익을 보인다. 즉, 보다 긴 (짧은) 과거 형성기간에 대한 모멘텀 전략은 보다 긴 (짧은) 미래 보유기간 동안에 지속적으로 유의한 투자성과를 갖는다. 둘째, 패자포트폴리오가 미래 기간에 갖는 양 $(+)$ 의 성과추이는 $\mathrm{W}-\mathrm{L}$ 무비용포트폴리오에서 관찰된 성과 변화 패턴과 그 통계적 유의성이 매우 유사하다. 셋째, 승자포트폴리오는 미래 보유기간 대부분에서 비유의한 투자성과를 보인다. 이러한 결과는 W-L 무비용포트폴리오에서 관찰된 미래 보유기간 1 개월에서 12 개월까지의 유의한 음(-)의 모멘텀 이익은 패자포트폴리오의 성과가 반전하여 지속적으로 양(+)의 값을 보여주는 것에 강하게 의존한다는 것을 의미한다.

지금까지 살펴본 거래량-모멘텀 기준 포트폴리오를 이용한 한국 주식시장에서의 음(-)의 모멘텀 이익에 대한 분석결과를 요약하면 다음과 같다. 첫째, 투자자의 관심이 높은 주식집단 (높은 거래량 회전율 주식집단) 내에서 유의한 음(-)의 모멘텀 이익이 확인되지만, 투자자 관심이 낮은 주식집단 (낮은 거래량 회전율 주식집단) 내에서는 유의한 결과를 확인할 수 없다. 둘째, 높은 거래량 회전율 주식집단 내에서 과거기간에 높은 투자성과를 실현한 승자포트폴리오는 미래 보유기간에서 성과가 큰 폭으로 하락하는 모습을 보여 비유의한 양(+)의 성과를 실현하고, 과거기간에 낮은 투자성과를 실현한 패자포트폴리오는 미래 기간에 큰 폭의 상승반전을 통해 유의한 양(+)의 성과를 실현한다. 음(-)의 모멘텀 이익에 대한 계절성 영향은 패자포트폴리오 보다는 승자포트폴리오에 보다 민감하게 작용한다. 즉, 1 월의 투자성과는 승자포트폴리오와 패자포트폴리오 모두 유의한 양(+)의 값을 갖지만, 나머지 월에서는 패자포트폴리오 만이 유의한 양(+)의 투자성과를 보인다. 셋째, 과거기간 승자/패자 포트폴리오를 구성하는 주식들을 과잉반응 정도에 따라 구분하는 경우 패자포트폴리오에서 나타나는 강한 성과반전은 높은 과잉반응 집단에서 더욱 크게 나타난다. 이는 $\mathrm{W}-\mathrm{L}$ 무비용포트폴리오에서 확인된 음(-)의 모멘텀 이익이 패자포트폴리오에서 나타나는 성과반전에 기인하며, 그 음(-)의 크기는 투자자의 과잉반응 정도가 높을수록 크게 나타남을 의미한다. 넷째, 처분효과에 근거하여 승자/패자 포트폴리오에 대한 투자자의 매도경향을 분석한 결과는 손실을 경험한 패자포트폴리오의 손실회피경향이 승자포트폴리오의 매도경향보다 높게 나타난다. 결국, 한국 주식시장에서 관찰된 음(-)의 모멘텀 이익은 승자포트폴리오 보다는 패자포트폴리오 성과의 상승반전에 보다 강하게 의존하며, 이러한 결과는 구성주식들이 과거기간 성과에 대한 투자자들의 과잉반응 정도와 구성주식들에 대한 매도경향(또는 손실회피경향)에 의미 있는 영향을 받음을 보여준다. 


\section{4. 주식시장 상황의 동적 특성과 모멘텀 효과}

이 장에서는 거래량-모멘텀 기준 포트폴리오로부터 확인된 음(-)의 모멘텀 이익에 대한 주식시장 상황의 동적 특성의 영향을 분석한다. 본 연구는 선행연구에 기초하여 과거기간과 미래기간의 시장상황을 4 가지로 구분한다. 첫째, 과거기간의 주식시장이 상승상황인 경우 양 $(+)$ 의 모멘텀 이익이 나타난다는 Cooper et al.(2004)의 결과를 참고하여, 과거기간에서의 주식시장의 상승/하락 상황이 모멘텀 효과에 미치는 영향을 조사한다. 검증결과는 <표 8>에 제시한다. 둘째, Hong and Stein(1999)에 근거하여, 미래 보유기간에서 상승/하락 시장상황이 모멘텀 효과에 미치는 영향을 분석한다. 이들은 미래기간에 상승시장인 경우 양(+)의 모멘텀 이익이 발생한다고 주장한다. 검증결과는 <표 8>에 제시한다. 셋째, Daniel et al.(1998)에 근거하여, 과거기간의 시장상황이 미래기간에서 동일하게 지속되는 지속시장과 상이한 상황이 발생하는 전환시장이 모멘텀 효과에 미치는 영향을 분석한다. 이들은 지속시장에서 양 $(+)$ 의 모멘텀 이익이 발생함을 제시한다. 이에 대한 검증결과는 <표 9>에 제시한다. 넷째, Asem and Tian(2010)에 기초하여, 과거기간과 미래기간의 상승/하락 시장상황의 가능한 조합이 모멘텀 효과에 미치는 영향을 분석한다. 이들은 상승-상승과 하락-하락의 지속시장에서 모두 양(+)의 모멘텀 이익을 확인했다. 이에 대한 검증결과는 <표 $10>$ 에 제시한다.

이상의 시장상황의 동적특성을 반영한 조건부 모멘텀 효과의 검증을 위해, 본 연구는 Cooper et al.(2004)의 방법에 따라 상승시장과 하락시장을 구분한다. 즉, 각 기간에서 시장지수의 보유기간성과가 양 $(+)$ 의 값을 갖는 경우는 상승시장으로, 음 $(-)$ 의 값을 갖는 경우는 하락시장으로 구분한다. 본 연구에서 사용되는 표본은 유가증권시장과 코스닥시장에서 거래되는 모든 주식들을 포함하였기 때문에, 분석에 포함된 모든 주식들의 가치가중수익률을 시장수익률로 이용하여 시장상황을 구분한다. 결과보고는 지면관계로 앞서 유의한 음(-)의 모멘텀 이익을 확인한 높은 거래량 회전율을 갖는 주식집단에 대한 검증결과만을 보고한다.

\section{1 과거기간과 미래기간의 주식시장 상황과 모멘텀 효과}

<표 8>에 과거기간과 미래기간 각각의 상승/하락 시장상황 하에서 거래량-모멘텀 포트 폴리오에 대한 분석결과를 나타낸다. 투자자는 하락시장에 비해 상승시장에서 보다 높은 관심과 거래활동을 갖는 경향이 있으며(Karlsson et al., 2009), 상승시장에서 투자자들은 높은 이익실현으로 위험회피성향이 낮아지고 보다 낙관적인 과잉반응을 보여 양(+)의 모멘텀 이익을 가져올 것으로 볼 수 있다(Daniel et al., 1998). <표 8>에서 모멘텀 전략은 앞의 검증결과에서 뚜렷하게 유의한 음(-)이 모멘텀 이익을 보인 $12 \mathrm{M} / 1 \mathrm{M}, 6 \mathrm{M} / 1 \mathrm{M}, 3 \mathrm{M} / 1 \mathrm{M}$ 의 3 가지를 이용한다. 하위기간 이동은 미래 보유기간이 겹치지 않는 방법을 채택하여 총 하위기간의 숫자는 228 개이다. 총 하위기간 중에서, 과거기간에 상승 시장상황은 형성기간 12 개월의 경우 205 개, 형성기간 6 개월의 경우 181 개, 그리고 형성기간 3 개월의 경우 157 개이다. 과거기간에 하락 시장상황은 형성기간 12 개월에 23 개, 형성기간 6 개월에 47 개, 그리고 형성기간 3 개월에 74 개이다. 한편, 미래기간에 상승, 하락 시장상황의 수는 과거 형성기간에 관계없이 상승 시장상황은 133 개 


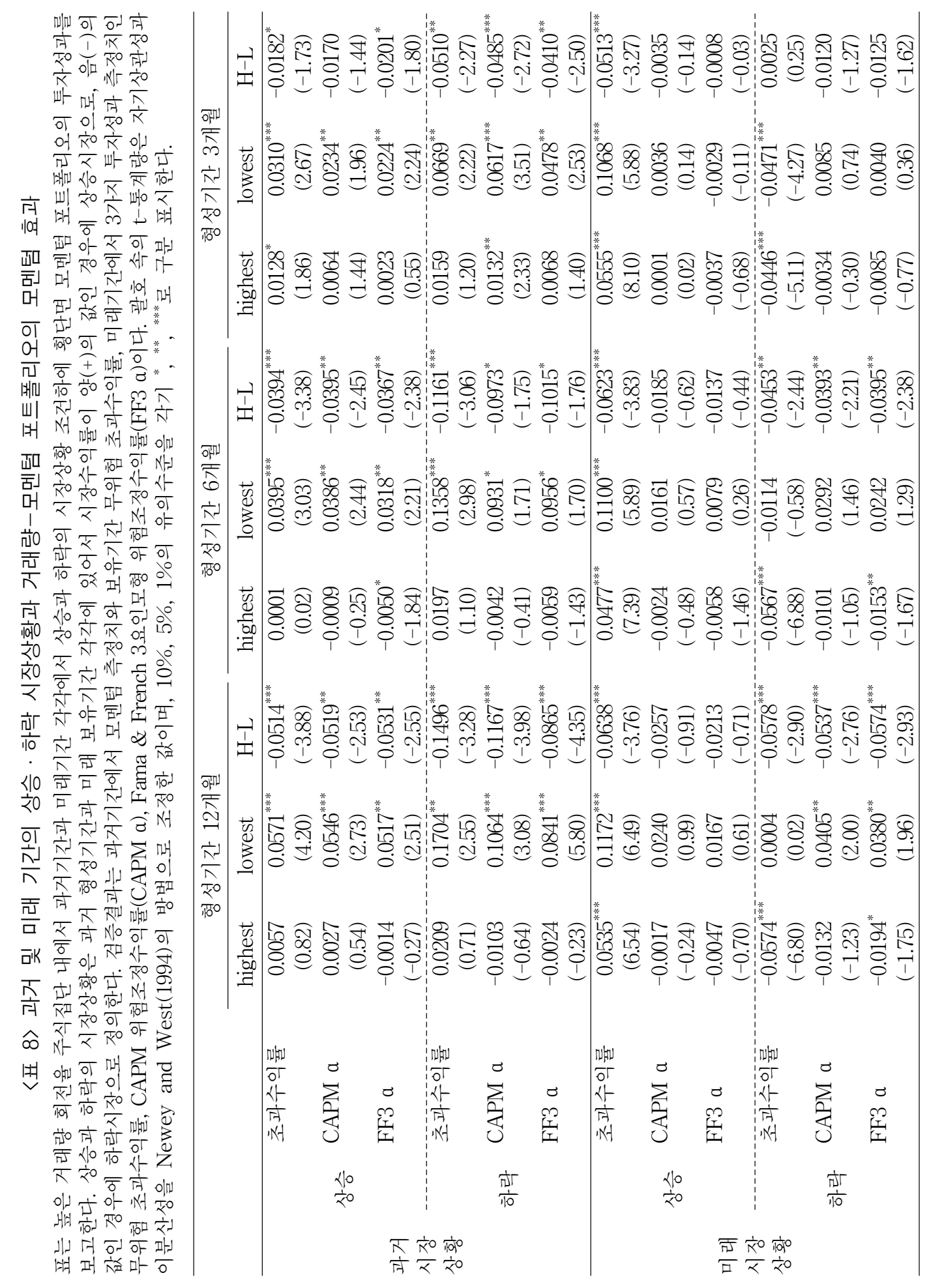


한국증권학회지 제49권 4호 (2020)

하위기간이고 하락 시장상황은 95 개 하위기간이다.13) 3 가지 투자성과인 초과수익률, CAPM 위험조정수익률, 그리고 $\mathrm{FF} 3$ 위험조정수익률을 보고한다.

$<$ 표 8>에 의하면, 한국 주식시장에서 과거기간과 미래기간 각각의 상승/하락 시장상황 여부에 관계없이, 높은 거래량 회전율 주식집단 내에서 모멘텀 전략은 유의한 음(-)의 모멘텀 이익을 보여준다. 즉, 과거 시장상황과 미래 시장상황 모두에서 $\mathrm{W}-\mathrm{L}$ 무비용 포트폴리오의 투자성과는 통계적으로나 경제적으로 유의한 음(-)의 모멘텀 이익을 갖는다. 또 통계적 유의성과 성과의 크기 면에서 과거 형성기간 12 개월에 대한 검증결과가 다른 형성기간에 비교하여 보다 뚜렷한 모습을 보인다. <표 8>의 결과를 과거 시장상황과 미래 시장상황으로 구분하여 구체적으로 살펴본다.

첫째, 과거 상승/하락 시장상황의 경우이다. 한국 주식시장에서는 Cooper et al.(2004)의 연구와 달리, 과거 상승 시장상황에서 유의한 양 $(+)$ 의 모멘텀 이익을 확인할 수 없다. W-L 무비용 포트폴리오의 성과는 형성기간 3개월의 CAPM 위험조정수익률을 제외하고 모두 유의한 음(-)의 값을 갖는다. 패자포트폴리오는 과거의 시장상황에 관계없이 모든 형성기간에서 유의한 양 $(+)$ 의 성과를 보이지만, 승자포트폴리오는 대부분이 비유의한 성과를 보인다. 결국, 과거의 시장상황을 고려한 거래량-모멘텀 포트폴리오에서 관찰된 $\mathrm{W}-\mathrm{L}$ 무비용포트폴리오의 유의한 음(-)의 모멘텀 이익은 승자포트폴리오가 아닌 패자포트폴리오에 기인한다는 것을 알 수 있다.14)

둘째, 미래 상승/하락 시장상황의 경우이다. 미래기간의 상승/하락 시장상황에서의 성과는 공통요인의 영향을 직접 받기 때문에, 3 가지 투자성과 측정치 중에서 초과수익률에 대한 유의성 평가로 모멘텀 효과의 증거를 평가한다.15) 한국 주식시장에서는 Hong and Stein(1999)과는 달리, 미래 상승 시장상황에서 거래량-모멘텀 포트폴리오로부터 양(+)의 모멘텀 이익을 확인할 수 없다. W-L 무비용포트폴리오의 초과수익률은 미래 하락기간의 형성기간 3개월을 제외하고 모두 유의한 음(-)의 값을 보인다. 미래 상승기간에서 패자포트폴리오와 승자포트폴리오는 모두 유의한 양(+)의 초과수익률을 갖는다. 미래 하락기간에서 승자포트폴리오는 과거 형성

13) 검증기간(2000.07 2019.06) 동안, 과거 포트폴리오 형성기간 기준 뿐만 아니라 미래 포트폴리오 보유기간 기준에 의해서도 상승 시장상황이 하락 시장상황보다 많다. 즉, 시장상황 조건부 모멘텀 효과 분석에서 한국 주식시장에서 관찰된 음(-)의 모멘텀 이익은 대만 주식시장을 분석한 Du et al.(2009)에서 보인 빈번한 하락시장과 전환시장이 음(-)의 모멘텀 이익을 발생시킨다는 결과와 차이가 있다.

14) 한편, 초과수익률의 크기를 비교하면, 과거 상승기간 보다는 과거 하락기간에서 관찰된 승자포트 폴리오와 패자포트폴리오의 투자성과가 크다. 즉, 승자포트폴리오에 있어서, 형성기간 12 개월에 대한 상승기간 투자성과(0.0057)는 하락기간 투자성과(0.0209)에 비교하여 27\%에 불과하고, 형성기간 6 개월은 $1 \%$, 형성기간 3 개월은 $29 \%$ 에 불과하다. 패자포트폴리오에 있어서 상승기간의 초과수익률은 하락기간에 비교하여 $34 \%$ (12개월), $29 \%$ (6개월), $88 \%$ (3개월)에 불과하다.

15) 국내연구(Eom, 2012; Eom et al., 2014)에서 상승기간과 하락기간 각각에서 시장위험프리미엄은 양 $(+)$ 과 음(-)의 값을 갖는 것을 보여준다. 만약 미래 상승기간이라면 시장위험프리미엄은 양 $(+)$ 의 값을 갖기 때문에, 양(+)의 보유기간 초과수익률로부터 양(+)의 프리미엄을 제외함으로서 위험조정 수익률은 보다 작은 양 $(+)$ 의 값을 가진다. 만약 음 $(-)$ 의 보유기간 초과수익률인 경우는 더욱 작은 음(-)의 위험조정수익률을 갖는다. 한편, 미래 하락기간이라면 시장위험프리미엄은 음 $(-)$ 의 값을 갖기 때문에, 양(+)의 보유기간 초과수익률로부터 음(-)의 프리미엄을 제외함으로서 위험조정 수익률은 보다 큰 양 $(+)$ 의 값을 가질 수 있고, 음 $(-)$ 의 보유기간 초과수익률의 경우는 보다 작은 음 $(-)$ 혹은 양 $(+)$ 의 위험조정수익률을 갖는다. 
Investor Attention, Market Dynamics, and Momentum in the Korean Stock Market

기간에 관계없이 유의한 음(-)의 초과수익률을 보이지만, 패자포트폴리오는 형성기간 3 개월을 제외하고 유의한 양 $(+)$ 의 초과수익률을 갖는다. 결국, $\mathrm{W}-\mathrm{L}$ 무비용포트폴리오로부터 확인된 유의한 음(-)의 초과수익률은 패자포트폴리오에 기인한 것임을 알 수 있다.16) 한편, 미래 상승/하락 시장상황에서 초과수익률의 크기를 비교하면, 미래 상승기간에서 관찰된 승자포트폴리오와 패자포트폴리오의 투자성과는 미래 하락기간에 비교하여 분명하게 큰 양(+)의 값을 갖는다.

\section{2 지속시장과 전환시장에서의 모멘텀 효과}

다음으로 <표 9>에서 과거 시장상황과 미래 시장상황 방향성의 지속 여부에 따라 구분된 지속시장과 전환시장에서의 모멘텀 효과를 살펴본다. 표에서 지속시장은 과거기간과 미래기간의 시장상황이 동일한 방향(상승-상승, 하락-하락)인 경우이다. 즉, 투자자들이 과거의 시장상황이 지속될 것으로 예상한 경우 그 상황이 발생한 경우로 볼 수 있다. 총 228 개 하위기간 중에서 형성기간 12 개월의 경우 130 개, 형성기간 6 개월에서 118 개, 그리고 형성기간 3 개월에서 113 개 하위기간의 지속시장 표본을 갖는다. 전환시장은 과거기간과 미래기간에 상이한 시장상황(상승하락, 하락-상승)이 발생한 경우이다. 총 하위기간 중에서 형성기간 12 개월에 98 개, 형성기간 6 개월에 110 개, 그리고 형성기간 3 개월에 115 개 하위기간의 전환시장을 갖는다.

$<$ 표 9>를 보면 형성기간에 관계없이 지속시장과 전환시장 모두에서 W-L 무비용포트폴리오의 투자성과는 모두 음(-)의 값을 보인다. 특히 전환시장에서의 $\mathrm{W}-\mathrm{L}$ 무비용포트폴리오는 형성 기간에 관계없이 모두 유의한 음(-)의 모멘텀 이익을 보이며, 지속시장에서는 형성기간 12 개월 에서 유의한 음(-)의 모멘텀 이익을 보인다. 즉, 모멘텀 전략은 지속시장 보다는 전환시장 에서 보다 유의한 음(-)의 모멘텀 이익을 지지하는 증거를 보인다.17) 패자포트폴리오는 형성기간에

16) 위험조정수익률에 대한 해석은 다음과 같다. 미래 상승/하락 시장상황에서 승자포트폴리오와 패자포트폴리오의 3가지 투자성과가 모두 유의한 값을 갖는 경우는 없다. 미래 상승/하락 시장상황 에서 보유기간 초과수익률은 위험조정수익률과는 달리 유의한 결과를 보인다. 즉, CAPM의 시장위험 프리미엄을 제거한 위험조정수익률, 그리고 규모프리미엄과 가치프리미엄을 함께 제거한 $\mathrm{FF} 3$ 위험조정수익률은 대부분이 비유의적이다. 미래 상승기간에서 승자포트폴리오와 패자포트폴리오의 보유기간 초과수익률은 $\mathrm{CAPM}$ 의 위험조정수익률에 비교하여 큰 값을 갖는다. 즉, 시장위험프리 미엄은 상승기간에 양(+)의 값을 갖는 것으로 알려져 있기 때문에, 보유기간 위험조정수익률을 감소시키는 경향을 확인할 수 있다. 미래 하락기간에서 승자포트폴리오와 패자포트폴리오의 보유기간 초과수익률은 $\mathrm{CAPM}$ 의 위험조정수익률에 비교하여 작은 값을 갖는다. 즉, 시장위험프리미엄은 하락기간에 음(-)의 값을 갖는 것으로 알려져 있기 때문에, 보유기간 위험조정수익률을 증가시키는 경향을 확인할 수 있다.

17) 모멘텀 효과에 대한 기존연구와 한국 주식시장의 관찰점 간의 차이점에 대한 가능한 설명은 다음과 같다. 기존연구에서 모멘텀 효과로부터의 양 $(+)$ 의 모멘텀 이익은 승자포트폴리오에 의존한다. 과거기간 높은 성과를 갖는 승자포트폴리오가 미래기간에서도 지속적으로 상승하는 투자성과를 갖기를 기대한다. 미래 상승시장은 승자포트폴리오 성과의 지속패턴에 긍정적 영향을 미치고, 미래 하락시장은 반대로 지속패턴에 부정적 영향을 미칠 것이다. 본 연구의 발견에 근거하면, 한국 주식시장에서 음(-)의 모멘텀 이익은 패자포트폴리에 의존한다. 과거기간 낮은 성과를 갖는 패자포트 폴리오는 미래기간에 반전패턴으로 상승하는 투자성과를 갖는데 미래 상승시장은 패자포트폴리오 성과의 반전패턴에 강화된 영향을 미치고, 미래 하락시장은 반대로 반전패턴에 부정적 영향을 미칠 것으로 예상할 수 있다. 


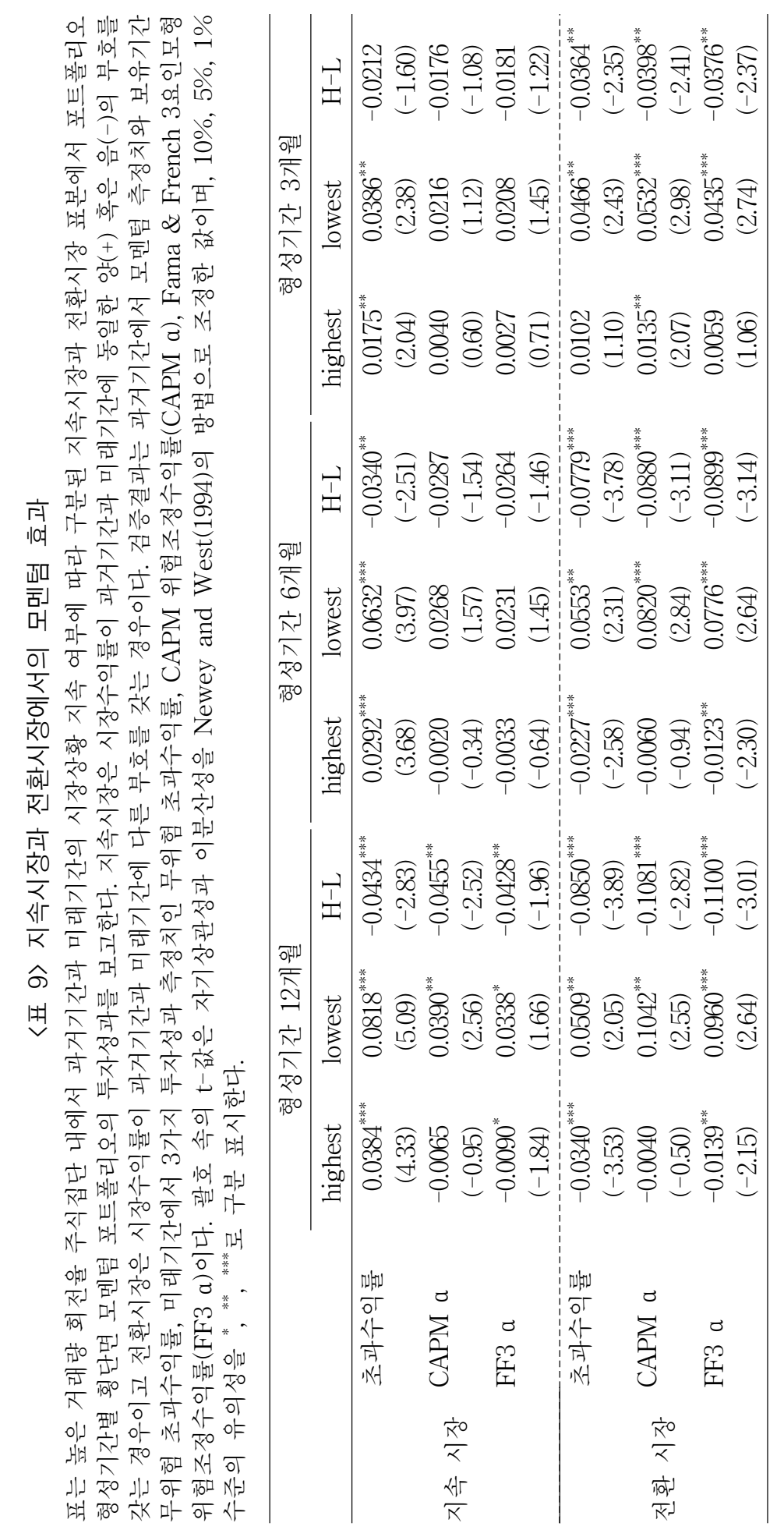


Investor Attention, Market Dynamics, and Momentum in the Korean Stock Market

관계없이, 지속시장과 전환시장 모두에서 양 $(+)$ 의 투자성과를 보이는데, 전환시장에서 패자포트 폴리오는 모두 유의한 양 $(+)$ 의 투자성과를 보이고 지속시장에서는 형성기간 12 개월에서 유의한 양(+)의 성과를 보인다. 즉, 패자포트폴리오는 지속시장 보다는 전환시장에서 보다 유의한 양(+)의 성과를 갖는다. 승자포트폴리오는 형성기간에 관계없이 지속시장에서 유의한 양(+)의 값을 갖지만, 전환시장에서는 대부분 유의한 음(-)의 값을 갖는다. 이는 승자포트폴리오가 전환시장 보다는 지속시장에서 유의한 양(+)의 투자성과를 갖는다는 것을 나타낸다.

승자포트폴리오와 패자포트폴리오 간의 분석결과의 차이는 다음과 같이 설명될 수 있다. 첫째, 지속시장에서 승자포트폴리오와 패자포트폴리오는 모두 양(+)의 성과를 갖지만, 그 크기를 보면 승자포트폴리오는 패자포트폴리오 보다 분명하게 작은 값을 갖는다. 이는 패자포트폴리오의 투자성과 반전패턴이 승자포트폴리오의 투자성과 지속패턴보다 강하게 작용하며, 결국 Daniel et al.(1998)의 연구와 달리 한국 주식시장에서 시장상황인 지속시장인 경우 음(-)의 모멘텀 이익이 나타남을 의미한다. 둘째, 전환시장에서 승자포트폴리오와 패자포트폴리오 간의 투자 성과는 분명한 차이를 갖는다. 패자포트폴리오는 전환시장에서 양 $(+)$ 의 투자성과를 보고하지만, 승자포트폴리오는 형성기간 3 개월을 제외하고 음 $(-)$ 의 투자성과를 보인다. 결국, 전환시장에서 승자포트폴리오의 음 $(-)$ 의 투자성과와 패자포트폴리오의 양 $(+)$ 의 투자성과에 기인하여 $\mathrm{W}-\mathrm{L}$ 무비용포트폴리오는 유의한 음(-)의 모멘텀 이익을 강하게 보여준다.18)

\section{3 시장상황의 동적 특성과 모멘텀 효과}

마지막으로, <표 10>에서 시장상황의 동적 특성에 따른 조건부 모멘텀 효과에 대한 분석결과를 살펴본다. Asem and Tian(2010)을 따라 과거기간과 미래기간에 대한 동적 시장상황의 가능한 조합인 상승-상승, 상승-하락, 하락-상승, 하락-하락의 4 가지 경우에서 모멘텀 이익의 존재를 분석한다. 상승-상승 조합은 형성기간 12 개월에서 120 개, 형성기간 6 개월에서 102 개, 그리고 형성기간 3 개월에서 86 개 하위기간을 갖는다. 상승-하락 조합은 형성기간 12 개월에서 85 개, 형성기간 6 개월에서 79 개, 그리고 형성기간 3 개월에서 68 개 하위기간을 갖는다. 하락-상승 조합은 각 형성기간에서 각각 13 개, 31 개, 그리고 47 개의 하위기간을 가지며, 하락-하락 조합은 각기 10 개, 16 개, 그리고 27 개의 하위기간을 갖는다. 한편, 시장상황의 동적 특성에 따른 모멘텀 효과에 대한 통계적 유의성은 과거기간과 미래기간의 시장상황이 동일한 경우와 상이한 경우에

18) 한편, 위험조정수익률 성과와 비교하면 패자포트폴리오의 초과수익률은 형성기간 3개월을 제외하고 지속시장이 전환시장 보다 높은 값을 갖지만, 위험조정수익률은 전환시장이 지속시장보다 높은 값을 보인다. 승자포트폴리오의 경우에도 역시 위험조정수익률은 초과수익률에 비교하여 전환시장 에서 보다 큰 값을 갖는 경향이 확인된다. 이와 같은 위험조정수익률과 초과수익률 간의 차이는 다음의 이유에서 설명된다. 위험조정수익률의 경우 지속시장은 패자포트폴리오 투자성과와 공통요인 간에 동일한 움직임 경향에 따라 공통요인에 대한 양 $(+)$ 의 프리미엄이 예상되지만 전환시장은 패자포트폴리오 투자성과와 공통요인 간에 상이한 움직임 경향에 따라 공통요인에 대한 음(-)의 프리미엄이 예상된다. 공통요인 프리미엄을 제거한 위험조정수익률에 있어서, 지속시장은 초과 수익률에 비교하여 위험조정수익률은 작은 값을 가질 수 있지만, 전환시장은 초과수익률에 비교하여 위험조정수익률은 큰 값을 가질 수 있다. 결국, 위험조정수익률의 크기 비교에서 전환시장이 지속시장보다 높은 값을 가질 수 있다. 


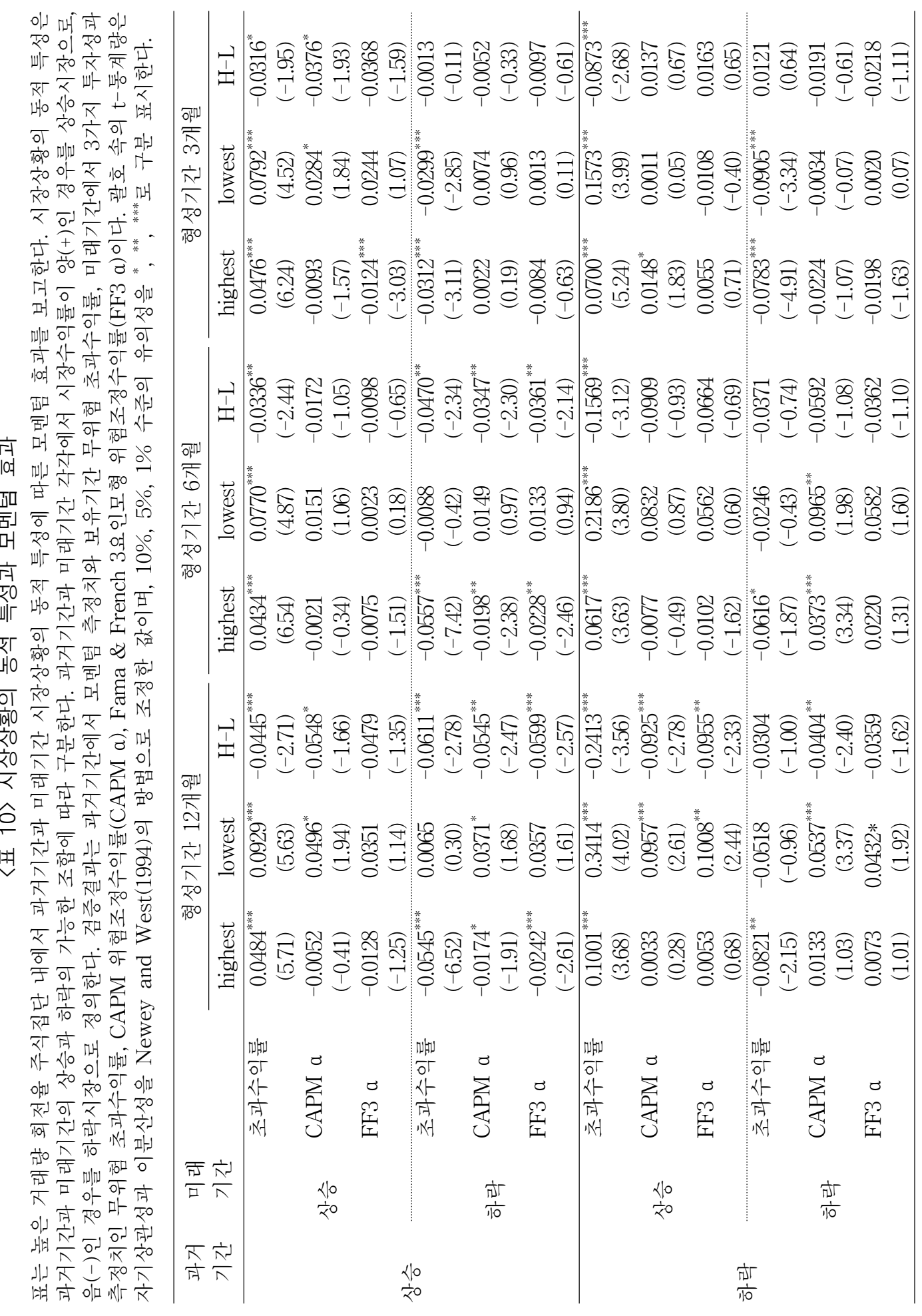


Investor Attention, Market Dynamics, and Momentum in the Korean Stock Market

다르게 적용한다. 즉 상승-상승 조합과 하락-하락 조합의 경우 승자포트폴리오와 패자포트 폴리오는 상승기간과 하락기간에서 알려진 공통요인의 영향을 직접적으로 받으므로 3 가지 투자성과 중에서 초과수익률을 중심으로 모멘텀 효과의 유의성을 검증한다. 반면에 동적 특성이 다른 경우(상승-하락, 하락-상승)에는 과거기간의 승자포트폴리오와 패자포트폴리오는 미래 기간의 시장상황과 무관하므로 보수적인 관점에서 3 가지 투자성과 모두에 대해 유의성을 검증하고 모멘텀 효과를 평가한다.

<표 10>의 결과를 보면 Asem and Tian(2010), Lin et al.(2016) 등의 결과와는 달리, 한국 주식시장에서 시장상황의 동적 특성을 고려한 후에도 모멘텀 효과는 대부분 유의한 음(-)의 값을 보여준다. 유의한 음(-)의 모멘텀 이익은 형성기간 12 개월에서 가장 강하게 나타나고, 동적 시장상황 중, 하락-하락 조합의 경우에만 유의한 음(-)의 모멘텀 이익을 확인할 수 없다. 4 가지로 구분된 동적 상황 각각에 대한 구체적인 결과를 살펴본다.

첫째, 상승-상승 조합에서 $\mathrm{W}-\mathrm{L}$ 무비용포트폴리오는 형성기간에 관계없이 통계적으로 유의한 음(-)의 모멘텀 이익(초과수익률)을 보여준다. 승자포트폴리오와 패자포트폴리오는 형성기간에 관계없이 유의한 양 $(+)$ 의 초과수익률을 가지며, 그 크기를 보면 패자포트폴리오가 승자포트 폴리오에 비하여 1.66배(3M) 1.93배(12M) 큰 값을 갖는다. 위험조정수익률은 대부분 유의성을 확인하기 어렵고, 공통요인에 대한 양 $(+)$ 의 프리미엄 효과에 따라 초과수익률보다 작은 값을 갖는다. 둘째, 하락-하락 조합에서 $\mathrm{W}-\mathrm{L}$ 무비용포트폴리오는 형성기간에 관계없이 모두 비유의한 음(-)의 모멘텀 이익(초과수익률)을 보고한다. 승자포트폴리오는 형성기간에 관계없이 유의한 음(-)의 초과수익률을 갖지만, 패자포트폴리오의 초과수익률은 형성기간 3 개월을 제외하고 모두 유의하지 않다. 위험조정수익률은 대부분 유의성을 확인하기 어렵고, 공통요인의 음(-)의 프리미엄 효과로 초과수익률보다 큰 값을 갖는다. 셋째, 상승-하락 조합에서 $\mathrm{W}-\mathrm{L}$ 무비용포트 폴리오는 형성기간 12 개월과 6 개월에서 3 가지 투자성과 모두가 유의한 음(-)의 모멘텀 이익을 보여주나 형성기간 3 개월에서는 유의한 결과를 확인할 수 없다. 승자포트폴리오는 형성기간 12 개월과 6 개월에서 유의한 음 $(-)$ 의 성과를 보이고, 패자포트폴리오는 형성기간에 관계없이 대부분 유의하지 않은 양(+)의 성과를 보인다. 또 패자포트폴리오의 초과수익률이 승자포트 폴리오에 비하여 0.16 배 $(6 \mathrm{M}) \sim 0.96$ 배(3M)의 범위를 보여 패자포트폴리오가 미래 하락시장에서 승자포트폴리오보다 덜 하락하는 모습을 보여준다. ${ }^{19)}$ 넷째, 하락-상승 조합에서 $\mathrm{W}-\mathrm{L}$ 무비용 포트폴리오는 형성기간 12 개월에서 3 가지 투자성과 모두가 유의한 음(-)의 모멘텀 이익을 보고한다. 패자포트폴리오는 형성기간 12 개월에서 유의한 양(+)의 성과를 보고하고, 승자포트 폴리오는 형성기간에 관계없이 대부분 유의하지 않은 양(+)의 성과를 보인다. 초과수익률을 보면 승자와 패자 포트폴리오 모두 유의한 양 $(+)$ 의 값을 갖고, W-L 무비용포트폴리오는 유의한 음(-)의 값을 보여준다. 초과수익률의 크기 비교에서 패자포트폴리오는 승자포트폴리오에

19) 형성기간 12 개월에 대한 패자포트폴리오와 승자포트폴리오의 비교는 각각 상이한 부호를 갖는 투자성과 때문에 크기 비교인 -0.15 배에 대한 의미 부여하기 어렵다. 즉, 과거기간 상승 시장상황에서 미래기간 예상치 못한 하락 시장상황으로 전환할 때, 승자포트폴리오는 의미 있는 음(-)의 투자성과를 갖는다는 것을 나타낸다. 
한국증권학회지 제49권 4호 (2020)

비교하여 2.25배(3M) 3.54배 $(6 \mathrm{M})$ 의 범위를 가져 과거기간 하락 시장이 미래기간에 상승 시장으로 전환할 때, 승자와 패자 포트폴리오는 모두 의미 있는 양(+)의 성과를 갖지만, 상승정도는 패자포트폴리오가 매우 높음을 보여준다.

한편, <표 $10>$ 의 결과를 지속시장과 전환시장으로 구분하여 승자포트폴리오와 패자포트 폴리오에 대한 투자성과를 비교하면 다음과 같다. 첫째, 지속 시장상황인 상승-상승과 하락하락의 경우에 승자포트폴리오는 각각 양 $(+)$ 의 초과수익률과 음 $(-)$ 의 초과수익률을 갖지만, 절대값 기준으로 비교하면, 하락-하락 상황에서의 초과수익률이 상승-상승 상황에서의 초과 수익률 보다 1.42 배( $6 \mathrm{M}) \sim 1.73$ 배(12M)의 범위에서 크다. 패자포트폴리오는 각각 양 $(+)$ 의 초과수익률과 음(-)의 초과수익률을 갖지만, 절대값 기준으로 비교하면, 하락-하락에서의 초과수익률이 상승-상승에서의 초과수익률 보다 $0.32(6 \mathrm{M}) \sim 1.14(3 \mathrm{M})$ 배로 평균적으로 작다. 결국, 지속시장에서 승자포트폴리오는 미래 상승기간보다 하락기간에서 보다 큰 하락을 경험하고, 패자포트폴리오는 미래 상승기간에 하락기간 보다 큰 상승을 경험한다. 둘째, 전환 시장상황인 상승-하락과 하락-상승의 경우에 승자포트폴리오는 각각 음 $(-)$ 의 초과수익률과 양 $(+)$ 의 초과 수익률을 갖지만, 절대값 기준으로 비교하면, 하락-상승에서 반전된 초과수익률의 상승정도가 상승-하락에서 반전된 초과수익률의 하락정도 보다 1.11 배(6M) 2.25배(12M)의 범위에서 크다. 패자포트폴리오는 각각에 대해 평균적으로 음 $(-)$ 의 초과수익률과 양 $(+)$ 의 초과수익률을 갖는 것은 승자포트폴리오와 동일하지만, 절대값 기준으로 비교하면, 하락-상승에서 반전된 초과 수익률의 상승정도는 상승-하락에서 반전된 초과수익률의 하락정도 보다 형성기간 12 개월의 41.6 배, 형성기간 6 개월의 24.9 배, 형성기간 3 개월의 5.3 배로 매우 큰 모습을 보인다. 결국, 전환시장에서 승자포트폴리오와 패자포트폴리오는 모두 미래 상승기간에서의 반전된 상승정도가 미래 하락기간에서의 반전된 하락정도보다 크고, 특히 패자포트폴리오의 경우에 반전된 상승 정도가 훨씬 크다. 흥미로운 점은 패자포트폴리오는 미래 반전된 상승 시장상황에서 승자포트 폴리오 보다 훨씬 높은 양( $(+)$ 의 초과수익률을 갖고, 미래 반전된 하락 시장상황에서는 승자포트 폴리오 보다 작은 음(-)의 초과수익률을 갖는다는 점이다.

\section{4 시장상황의 동적 특성과 한국 주식시장의 모멘텀 효과: 선행연구와의 비교}

지금까지 <표 8>, <표 9>, <표 10>에서 살펴본 결과를 기존연구와 비교하여 정리하면 다음과 같다. 먼저, 과거기간의 상승 시장상황에 주안점이 있는 Cooper et al.(2004)의 결과와 비교하면, 한국 주식시장에서 과거기간과 미래기간의 시장상황의 특성이 상승-상승인 경우 승자포트폴리오와 패자포트폴리오는 모두 유의한 양 $(+)$ 의 초과수익률을 갖지만, 패자포트 폴리오가 승자포트폴리오에 비하여 보다 큰 양 $(+)$ 의 초과수익률을 가져, $\mathrm{W}-\mathrm{L}$ 무비용포트 폴리오는 유의한 음(-)의 모멘텀 이익을 실현한다. 둘째, 시장상황의 동적 특성이 상승-하락인 경우 승자포트폴리오는 유의한 음(-)의 초과수익률을, 패자포트폴리오는 승자포트폴리오에 비하여 작고 비유의한 음(-)의 초과수익률을 갖는다. 따라서 $\mathrm{W}-\mathrm{L}$ 무비용포트폴리오는 대부분 유의한 음(-)의 모멘텀 이익을 보고한다. 이러한 결과는 한국 주식시장에서의 모멘텀 효과가 Cooper et al.(2004)의 결과와 질적으로 다름을 보여주는 것이다. 
Investor Attention, Market Dynamics, and Momentum in the Korean Stock Market

다음으로, 미래기간의 상승 시장상황에 주안점이 있는 Hong and Stein(1999)의 결과와 비교하면, 첫째, 시장상황의 동적 특성이 상승-상승인 경우에는 앞서 살펴본 것과 같이 $\mathrm{W}-\mathrm{L}$ 무비용포트폴리오는 유의한 음(-)의 모멘텀 이익을 갖는다. 둘째, 시장상황의 동적 특성이 하락-상승인 경우에 승자포트폴리오와 패자포트폴리오는 모두 유의한 양 $(+)$ 의 초과수익률을 갖지만, 패자포트폴리오가 승자포트폴리오 보다 큰 양(+)의 초과수익률을 실현하고 이에 따라 $\mathrm{W}-\mathrm{L}$ 무비용포트폴리오는 유의한 음(-)의 모멘텀 이익을 갖는. 이는 한국 주식시장의 모멘텀 효과의 특성이 Hong and Stein(1999)에서와 같이 미래기간의 상승 시장상황 특성에 영향을 받으나, 음(-)의 모멘텀 이익이 확인된다는 점에서 차별적인 모습을 갖는다.

마지막으로, 과거와 미래의 시장상황의 지속성에 주안점이 있는 Daniel et al.(1998), Asem and Tian(2010)의 연구와 비교하면, 첫째, 시장의 동적 특성이 상승-상승인 경우 앞서 살펴본 것과 같이 W-L 무비용포트폴리오는 유의한 음(-)의 모멘텀 이익을 보고한다. 둘째, 하락-하락의 시장상황에서는 승자포트폴리오는 유의한 음(-)의 초과수익률을 갖고, 패자포트폴리오는 비유의한 음(-)의 초과수익률을 보여 W-L 무비용포트폴리오는 비유의한 음(-)의 모멘텀 이익을 갖는다. 결국 Daniel et al.(1998), Asem and Tian(2010)에서와 같이 한국 주식시장에서도 과거기간과 미래기간에 상승-상승의 지속시장 상황이 모멘텀 효과에 영향을 미치나 그 부호는 음(-)의 모멘텀 이익이 확인된다는 점이 차별적이다. 또 한국 주식시장에서 하락-하락의 지속시장 상황에서 비유의한 모멘텀 효과가 관찰된다는 점 역시 기존연구와 다른 점이다. 하지만, 한국 주식시장에서 보이는 음(-)의 모멘텀 이익은 Asem and Tian(2010)이 일본 주식시장에서 관찰한 결과와는 일치하는 모습을 보이는 것이다.20)

\section{5. 강건성 분석: 잔차모멘텀과 잔차거래량회전율을 이용한 모멘텀 효과 검증}

\section{1 잔차모멘텀을 이용한 모멘텀 효과의 검증}

본 절에서는 Blitz et al.(2011)에 기초하여 잔차모멘텀을 이용하여 모멘텀 효과를 검증한 결과를 제시한다. 전통적 모멘텀은 Jegadeesh and Titman(1993)과 같이 주식수익률에 포함된 속성을 통제하지 않고 원래 수익률자료를 이용하여 모멘텀 효과를 조사하는 것이다. 잔차모멘텀은 Blitz et al.(2011)과 같이 가격결정모형에서 공통요인의 속성을 제거한 기업특성요인의 속성을

20) Daniel and Moskowitz(2016)는 모멘텀 전략이 시장 추세 외에도 시장 변동성과 밀접한 관련이 있음을 보고하였다. 한국주식시장에 있어서 Park and Jee(2006)는 시장 변동성과 개별주식의 변동성이 모멘텀 이익에 유의한 영향을 미친다는 증거를 제시하였다. 또한 Cooper et al.(2004)는 거시 경제 변수들이 모멘텀 효과에 미치는 영향에 대해 언급하였다. 본 연구는 과거기간과 미래기간에 나타나는 시장의 동적 특성을 4가지 상황으로 구분하고 동적 상황 특성에 따른 모멘텀 이익을 분석하는 것을 연구범위로 설정하였기 때문에, 변동성과 거시경제변수가 모멘텀 효과에 미치는 영향에 대한 구체적인 분석은 후속연구과제로 남긴다. 
한국증권학회지 제49권 4호 (2020)

갖는 잔차수익률을 이용하여 모멘텀 효과를 분석한다.21) 이들의 연구에 의하면, 잔차모멘텀은 전통적 모멘텀과 같이 유의한 양(+)의 모멘텀 이익의 보이지만, 잔차모멘텀으로부터의 투자 성과가 전통적 모멘텀의 투자성과보다 안정적이고 큰 값을 갖는다는 차이를 보인다. 본 연구는 다음의 3 가지 관점에서 분석을 진행한다. 첫째, 과거기간에 높은 잔차수익률을 갖는 주식들로 구성된 승자포트폴리오와 과거기간에 낮은 잔차수익률을 갖는 주식들로 구성된 패자포트폴리오 간의 차이인 W-L 무비용포트폴리오가 유의한 양(+)의 모멘텀 이익을 갖는지를 확인한다. 둘째, 잔차모멘텀으로부터의 투자성과가 전통적 모멘텀으로부터의 투자성과 보다 큰 값을 갖는지를 관찰한다. 셋째, 잔차모멘텀의 검증결과가 투자자 관심이 낮은 주식집단보다 투자자 관심이 높은 주식집단 내에서 더욱 분명한지 여부를 확인한다. 본 연구는 미래 보유기간 1 개월에 대한 <표 3>의 횡단면 모멘텀과의 비교를 위해 동일한 검증조건에서 $3 \times 5$ 거래량-잔차모멘텀 포트폴리오로부터의 검증결과를 <표 $11>$ 에 제시하고, 미래 보유기간의 확대(1개월 $\rightarrow 12$ 개월)에 대한 <표 $7>$ 의 횡단면 모멘텀과의 비교를 위해 동일한 검증조건에서 $3 \times 5$ 거래량-잔차모멘텀 포트폴리오로부터의 검증결과를 <표 $12>$ 에 제시한다.

<표 11>은 미래보유기간 1 개월에 대한 거래량-잔차모멘텀 포트폴리오에 대한 분석결과를 제시한 것이다. 잔차수익률은 시장위험프리미엄, 규모프리미엄, 가치프리미엄을 공통요인으로 포함한 Fama-French 3-요인모형(1993)으로부터 추정한다.22) 검증기간(2000.07 2019.06)에 있어서 3 가지 모멘텀 투자전략 $(12 \mathrm{M} / 1 \mathrm{M}, 6 \mathrm{M} / 1 \mathrm{M}, 3 \mathrm{M} / 1 \mathrm{M})$ 에 대한 분석결과는 과거기간의 잔차수익률에 의한 모멘텀 측정치와 보유기간 초과수익률, 미래기간의 3 가지 투자성과 측정치인 초과수익률, $\mathrm{CAPM}$ 위험조정수익률, $\mathrm{FF} 3$ 위험조정수익률을 보고한다.

<표 11>의 결과를 보면 높은 거래량 회전율 주식집단에 대한 W-L 무비용포트폴리오는 모두 유의한 음(-)의 모멘텀 이익을 보이지만, 낮은 거래량 회전율 주식집단에서는 유의한 음(-)의 모멘텀 이익을 확인할 수 없다. 미래기간의 투자성과를 살펴보면, 높은 거래량 회전율 주식집단의 W-L 무비용포트폴리오는 과거 형성기간에 관계없이 3가지 투자성과 측정치 모두가 유의한 음(-)의 값을 갖지만, 낮은 거래량 회전율 주식집단은 대부분 비유의한 값을 갖는다. 그리고 높은 거래량 회전율 주식집단의 $\mathrm{W}-\mathrm{L}$ 무비용포트폴리오에 대한 보유기간 초과수익률의 크기는 낮은 거래량 회전율 주식집단에 비교하여 4.24 배 6.77배의 범위에서 큰 값을 보인다.

21) 한국 주식시장에 있어서 규모효과와 모멘텀의 관계를 검증한 $\operatorname{Eom}(2013)$ 은 외환위기 이후기간 (1998.07 2009.12)에서 소규모 주식들과 외국인 지분율이 높은 주식들에서 양 $(+)$ 의 모멘텀을 지지하는 증거를 보고한다. 이는 기업규모와 모멘텀 효과간의 유의한 관계를 시사한다. 한편, Eom et al.(2014)은 한국 주식시장에 있어서 규모효과는 과거기간에 비교하여 최근에 유의한 증거를 확인하기 어렵다는 결과를 보고한다. 따라서 Blitz et al.(2011)에 근거하여 3요인(시장요인, 규모요인, 가치요인)을 제거한 잔차수익률을 이용한 모멘텀 효과의 검증결과는 규모의 영향을 통제한 증거로 볼 수 있고, 또한 유의한 결과는 모멘텀 효과가 규모효과에 의해 모두 설명되는 현상이 아님을 의미한다.

22) 본 연구는 CAPM으로부터 추정된 잔차수익률을 이용하여 동일하게 거래량-잔차모멘텀 포트폴리오를 검증 하였으나, 논문의 지면관계로 보고하지 않았다. CAPM 잔차수익률을 이용한 검증결과는 본문에 보고한 Fama-French 3-요인모형으로부터의 검증결과와 질적으로 다르지 않다. 


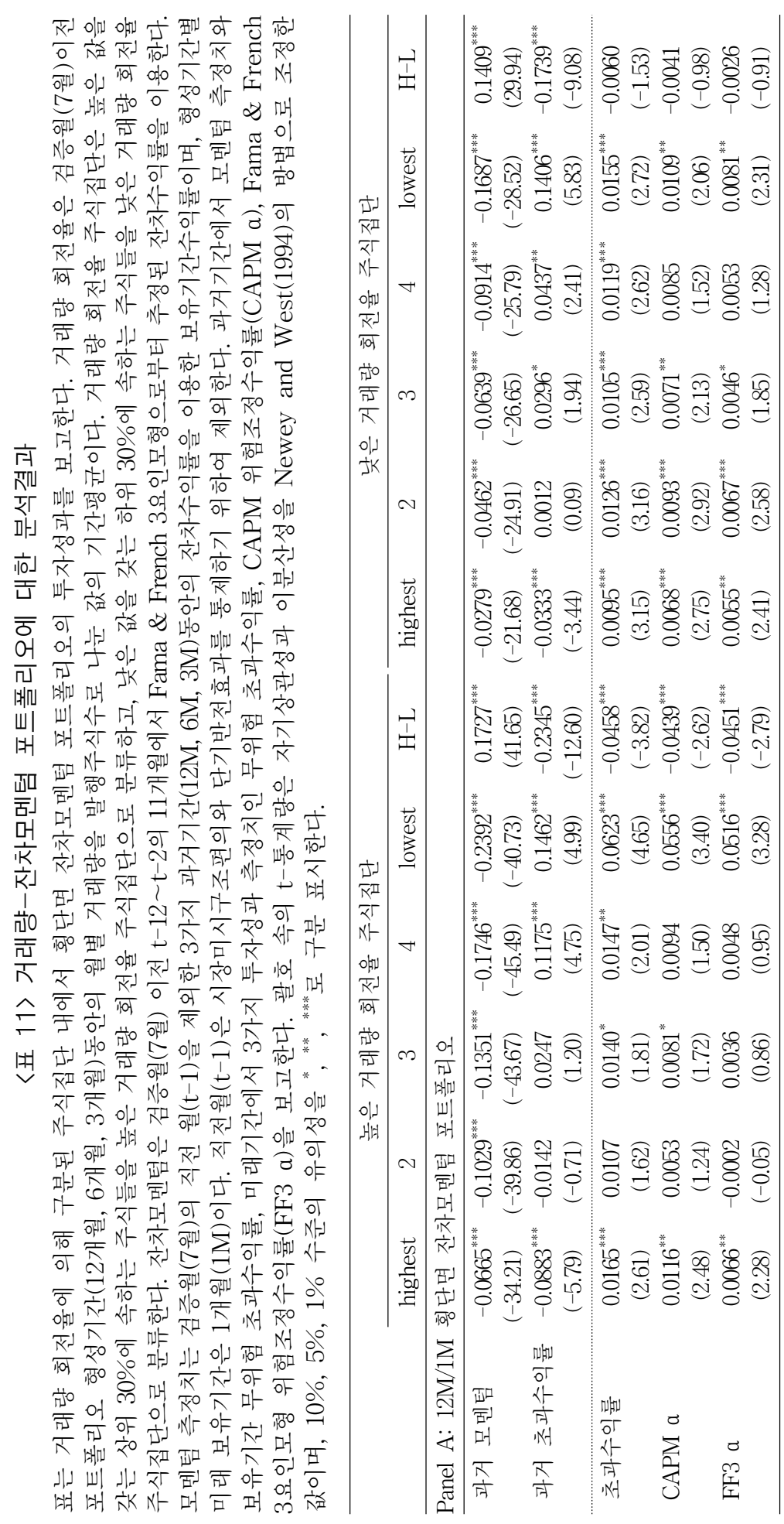




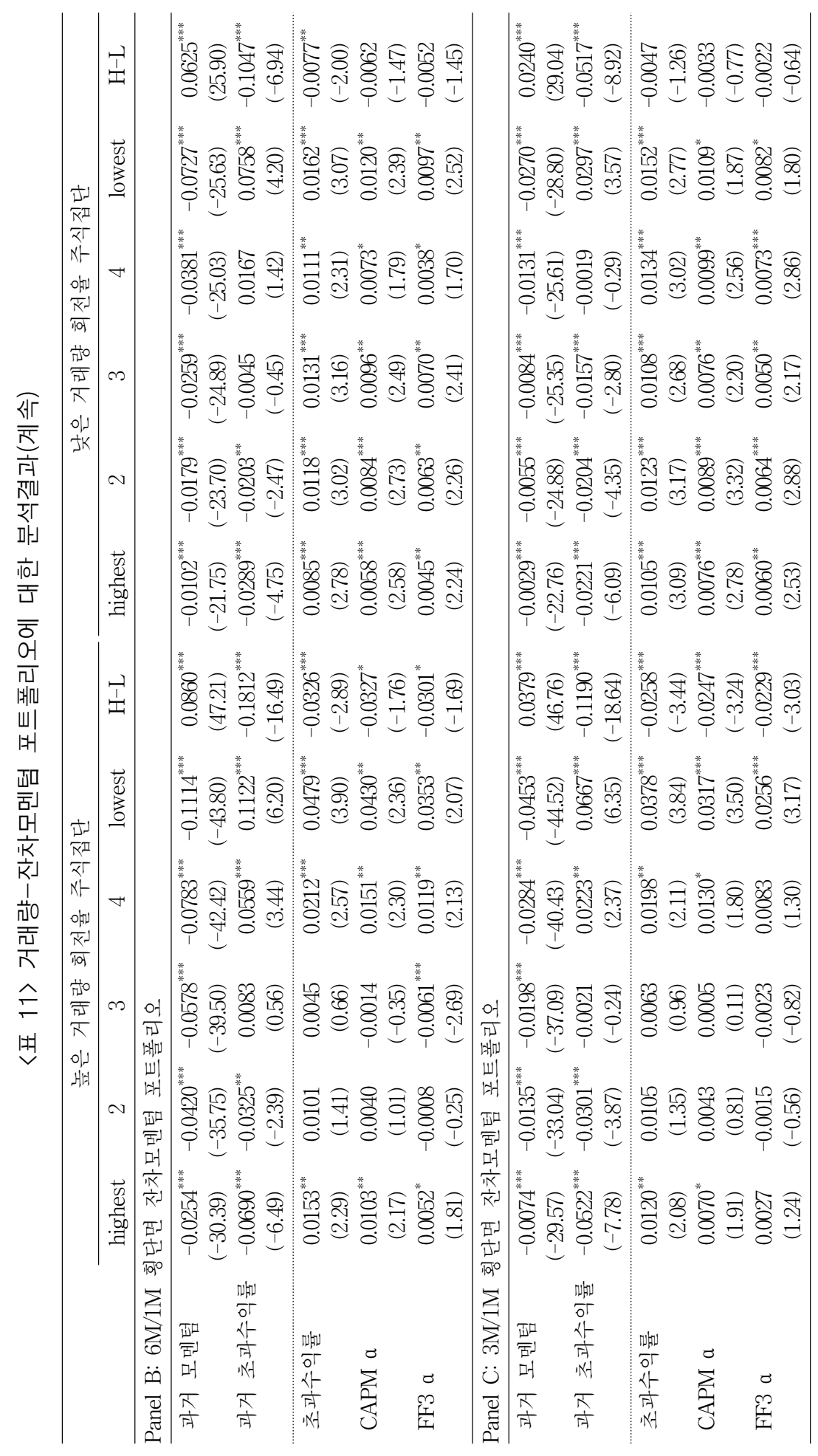


Investor Attention, Market Dynamics, and Momentum in the Korean Stock Market

승자포트폴리오의 경우, 높은 거래량 회전율 주식집단은 낮은 거래량 회전율 주식집단에 비교하여 1.14 배 1.72 배 범위에서 큰 값을 갖고, 패자포트폴리오의 경우 높은 거래량 회전율 주식집단은 낮은 거래량 회전율 주식집단에 비하여 2.48 배 3.82 배 범위에서 큰 값을 갖는다. 즉, $\mathrm{W}-\mathrm{L}$ 무비용포트폴리오의 투자성과는 승자포트폴리오 보다는 패자포트폴리오에 보다 의존한다는 것을 알 수 있다. 23$)$ 즉, 한국 주식시장에서 잔차 모멘텀의 승자포트폴리오가 유의한 양(+)의 투자성과를 실현하는 것과 함께 패자포트폴리오는 보다 크고 유의한 양(+)의 투자성과를 실현하기 때문에 음(-)의 모멘텀 이익을 보여준다. 그리고 <표 3>에서와 마찬가지로 잔차모멘텀을 이용한 검증 결과도 높은 거래량 회전율을 갖는 주식집단 내에서 유의한 음(-)의 모멘텀 이익이 확인된다. <표 3>에서 확인된 전통적 모멘텀의 검증결과와 비교하면, 승자포트폴리오에 대한 투자성과는 전통적 모멘텀으로부터의 투자성과보다 유의적이고 큰 값을 갖는다. 하지만, 패자포트폴리오는 반대로 잔차모멘텀의 투자성과가 작은 값을 갖는다. 그러나 전체적으로 볼 때 <표 $11>$ 에서 보고되는 W-L 무비용포트폴리오의 유의한 음 $(-)$ 의 모멘텀 이익은 <표 $3>$ 의 결과와 유사하며 이러한 특성은 패자포트폴리오의 보다 높은 투자성과에 지배적으로 영향을 받는다.

한편, <표 11>에서 흥미로운 점은 잔차수익률을 이용하여 구성된 승자포트폴리오와 패자포트 폴리오의 잔차모멘텀이 과거기간 초과수익률과 양 $(+)$ 의 관계를 갖지 않는다는 것이다. 즉, <표 $3>$ 에서와 달리, 가장 높은 (낮은) 모멘텀 측정치를 갖는 승자(패자)포트폴리오가 가장 높은 (낮은) 보유기간 초과수익률을 갖지 않는다. <그림 3>은 전통적 모멘텀과 잔차 모멘텀에 있어서 과거기간 모멘텀 측정치와 과거기간 초과수익률 간의 관계를 산포도를 이용하여 시각적으로 보여준다.

전통적 모멘텀과 잔차모멘텀 간의 차이는 수익률자료에 포함된 속성 차이로 설명된다. 잔차모멘텀 포트폴리오를 구성하는데 이용된 잔차수익률은 개별주식의 수익률자료에 포함된 공통요인 프리미엄이 제거되었기 때문에, 원래 주식수익률자료에 포함된 공통요인 변화에 따른 프리미엄이 포함되어 있지 않다. 따라서 잔차수익률을 이용하여 산출된 모멘텀 측정치와 원래 주식수익률을 이용하여 산출된 초과수익률 간에 기대하는 양(+)의 관계를 확인하기 어렵다. 결국 <표 $11>$ 에서 보듯이 승자포트폴리오가 가장 높은 초과수익률을 갖지 않고, 패자포트 폴리오가 가장 작은 초과수익률을 갖지 않는다.

다음으로, <표 $12>$ 에는 높은 거래량 회전율 주식집단 내에서 미래 보유기간을 1 개월에서 12 개월로 장기화함에 따른 잔차모멘텀 효과를 분석한 결과를 제시한다. Daniel et al.(1998)의 과잉신뢰가설에 따라, 미래 보유기간의 장기화됨에 따른 잔차모멘텀 포트폴리오의 투자성과 지속패턴 이후 반전패턴을 관찰한다. 미래 보유기간은 <표 $7>$ 과 동일하게 1 개월, 3 개월, 6 개월, 12 개월의 4 가지로 설정하고, 하위기간의 기간이동도 역시 보유기간이 겹치지 않는 방법을 채택한다.

23) 한편, 앞의 <표 3>에서 확인된 결과와의 차이는 다음과 같다. 승자포트폴리오는 높은 거래량 회전율 주식집단의 형성기간 3 개월을 제외하고 모든 경우에서 잔차모멘텀으로부터의 투자성과가 전통적 모멘텀의 투자성과보다 큰 값을 갖는다. 그리고 전통적 모멘텀으로부터의 승자포트폴리오 투자성과는 비유의적이지만, 잔차모멘텀의 투자성과는 유의하다. 패자포트폴리오는 높은 거래량 회전율 주식집단에 있어서 전통적 모멘텀으로부터의 투자성과가 잔차모멘텀의 투자성과보다 큰 값을 갖는다. 결국, Blitz et al.(2011)의 주장과 같이 전통적 모멘텀의 투자성과보다 잔차모멘텀의 투자성과가 보다 크고 유의한 투자성과를 실현한다는 주장은 한국 주식시장의 경우에 승자포트폴리오에만 해당한다. 
〈그림 3〉 과거기간 모멘텀과 과거기간 초과수익률 간의 관계

그림은 거래량 회전율에 의하여 구분된 2 가지 주식집단 $(\mathrm{H}, \mathrm{L})$ 내에서 횡단면 모멘텀(<그림 $\mathrm{a}>$ )과 잔차모멘텀 $(<$ 그림 $\mathrm{b}>$ ) 각각을 기준으로 구성된 5 분위 포트폴리오에 대한 모멘텀 측정치와 포트폴리오 보유기간 초과수익률을 비교한 것이다. 모멘텀 측정치는 검증월( 7 월) 이전 과거기간 $\mathrm{t}-12 \sim \mathrm{t}-2$ 의 11 개월 동안의 보유기간수익률을 나타낸다. 포트폴리오 보유기간 초과수익률은 포트폴리오 구성주식의 수익률에서 무위험수익률을 차감하고, 과거 t-12 t-2의 11 개월 동안의 기간수익률을 나타낸다. 그림에서, 모멘텀 측정치는 막대그래프 $(\mathrm{H}$ : 높은 거래량 회전율, $\mathrm{L}$ : 낮은 거래량 회전율)로 나타내고, 보유기간 초과수익률은 선그래프( $\bigcirc$ : 높은 거래량 회전율, $\square$ : 낮은 거래량 회전율)로 나타낸다. X축의 5 분위 포트폴리오는 과거 가장 높은 모멘텀 측정치를 갖는 포트폴리오(highest)에서 가장 낮은 모멘텀 측정치를 갖는 포트폴리오 (lowest)로 구분 표시한다. $\mathrm{Y}$ 축은 모멘텀 측정치(왼쪽 $\mathrm{Y}$ 축)와 보유기간 초과수익률(오른쪽 $\mathrm{Y}$ 축)의 2중축으로 구분 표시한다.

(a)

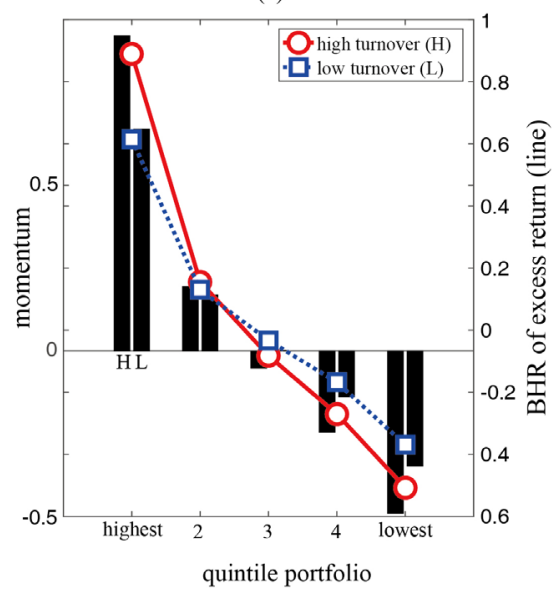

(b)

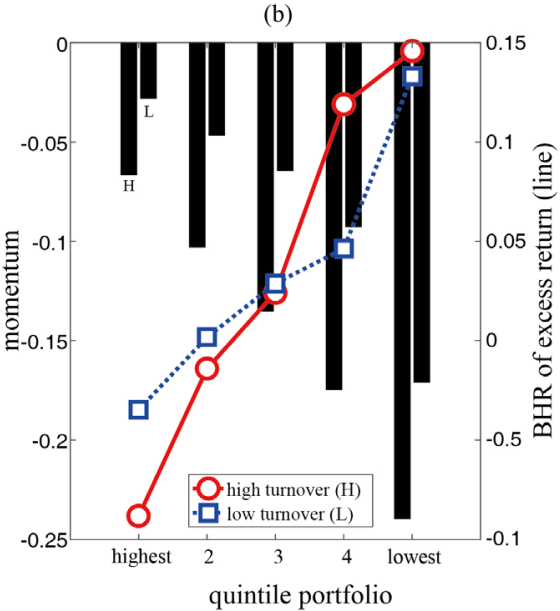

<표 12>에 의하면, 높은 거래량 회전율 주식집단에 대한 W-L 무비용포트폴리오 투자성과는 미래 보유기간을 1 개월에서 6 개월까지 늘릴 때 과거 형성기간에 관계없이 모두 음(-)의 값을 갖는다. 형성기간 12 개월과 3 개월에 대한 잔차모멘텀 전략은 보유기간 3 개월까지 유의한 음(-)의 모멘텀 이익을 보이고, 형성기간 6 개월의 잔차모멘텀 전략은 미래 보유기간 1 개월에 대해서만 유의한 음(-)의 모멘텀 이익을 갖는다. 즉, <표 7>의 전통적 모멘텀으로부터 관찰된 $\mathrm{W}-\mathrm{L}$ 무비용포트폴리오에 비교하여 잔차모멘텀으로부터의 W-L 무비용포트폴리오의 음(-)의 성과는 미래기간에 지속패턴을 보이지 않고 보다 빨리 반전한다.24) 미래 보유기간을 늘림에 따라 나타나는 전통적 모멘텀 효과와의 차이는 흥미롭게도 과거기간 패자포트폴리오가 아닌 승자포트폴리오에 기인한다. 잔차모멘텀에 있어서 패자포트폴리오는 전통적 모멘텀에서와 유사하게 유의한 양(+)의 투자성과를 갖고 그 성과의 크기도 유사하다. 하지만, 잔차모멘텀에 있어서 승자포트폴리오는 전통적 모멘텀과 달리 대부분 유의한 양(+)의 투자성과를 갖는다. 또한 미국 주식시장을 대상으로

24) 잔차모멘텀은 개별주식의 수익률자료에 포함된 공통요인의 속성을 제거한 후에 개별기업 속성이 지배적인 잔차수익률을 이용하여 승자포트폴리오와 패자포트폴리오를 구성하였기 때문에, 전통적 모멘텀으로부터 관찰된 투자성과의 지속성 보다 짧은 지속성을 보이는 것은 제거된 공통요인의 속성이 미래 보유기간 지속성에 의미 있는 영향을 미칠 수 있다는 것을 의미한다. 


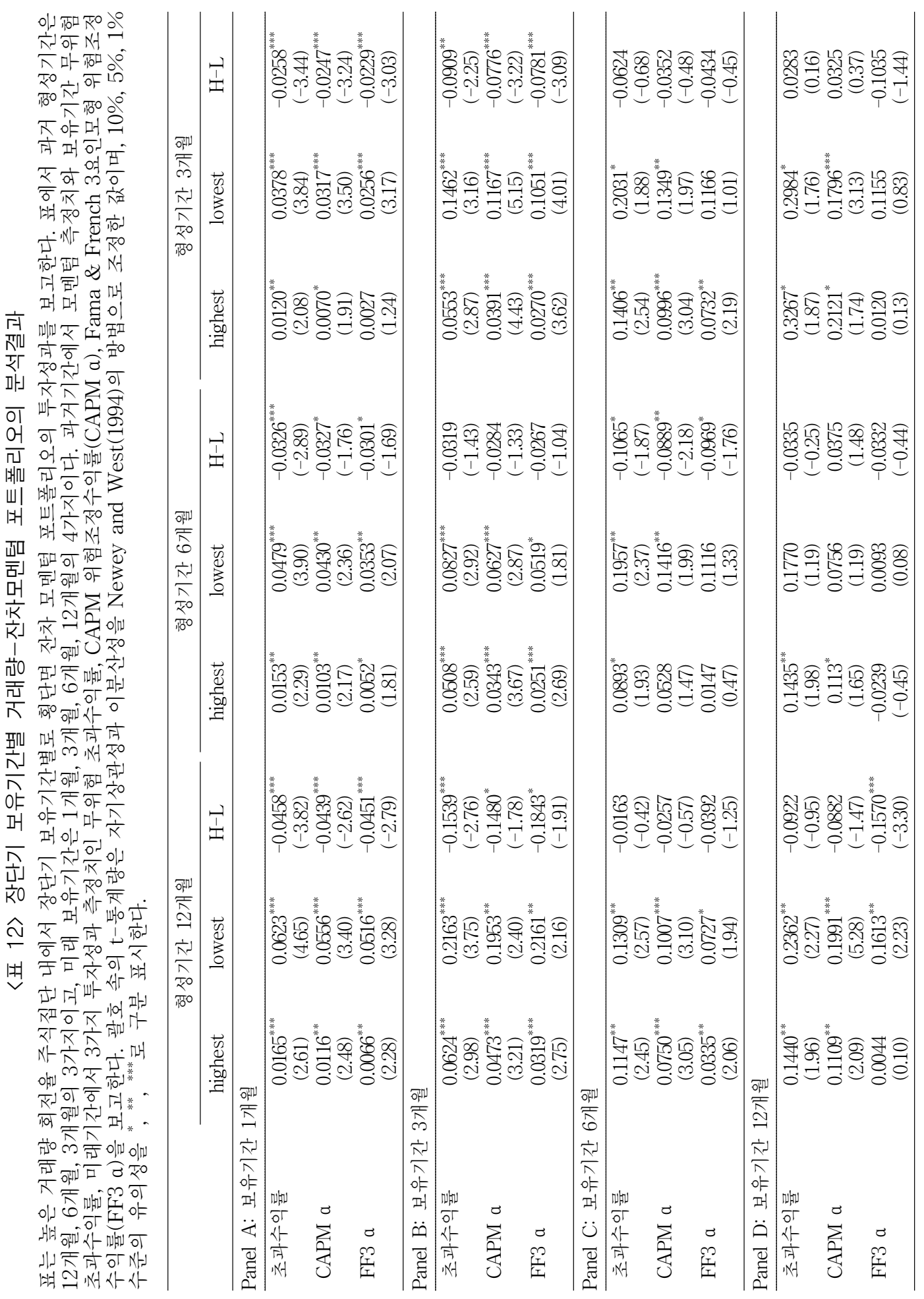


한국증권학회지 제49권 4호 (2020)

한 Blitz et al.(2011)의 검증결과가 전통적모멘텀 보다 높은 투자성과를 갖는 것은, 잔차모멘텀의 승자포트폴리오가 미래 보유기간에 보다 높은 투자성과를 갖는 것에 기인한다. 하지만, 한국 주식시장의 경우에는 승자포트폴리오에서 유사한 투자성과 패턴이 나타나더라도 패자포트 폴리오의 강한 반전에 의해 실현된 높은 투자성과보다는 작은 값을 갖기 때문에, $\mathrm{W}-\mathrm{L}$ 무비용 포트폴리오는 여전히 유의한 음(-)의 모멘텀 이익을 보이는 것으로 해석할 수 있다.

\section{2 잔차거래량-모멘텀 포트폴리오에 대한 분석 결과}

본 절에서는 투자자관심의 대용변수인 거래량 회전율과 모멘텀 효과의 관계에 대한 강건성을 검증한다. Datar et al.(1998), Shalen(1993) 등은 거래량이 유동성이나 변동성과 밀접한 관계를 갖는 것을 보여준다. 본 연구에서는 Hou et al.(2009), Lin et al.(2016)의 연구방법에 기초하여 앞서 살펴본 거래량 회전율과 모멘텀 효과 간의 관계가 유동성이나 변동성에 대한 상관관계에 영향을 받지 않는 강건한 관계임을 입증한다. 이를 위해 과거기간 개별주식의 거래량 회전율을 종속변수로 변동성과 유동성을 독립변수로 하는 횡단면 회귀모형으로부터 추정된 잔차를 유동성과 변동성의 영향을 통제한 잔차 거래량회전율로 정의한다. 개별주식의 변동성은 수익률의 표준편차로 측정하고, 유동성은 Amihud(2002)의 비유동성 측정치를 이용한다. 미래 보유기간 1 개월에 대한 <표 $3>$ 의 결과와의 비교를 위해 동일한 검증조건에서 $3 \times 5$ 잔차거래량-모멘텀 포트폴리오를 구성하고 그에 대한 검증결과를 <표 $13>$ 에 제시한다. 또 미래 보유기간의 확대 ( 1 개월 $\rightarrow 12$ 개월)에 따른 분석결과인 <표 $7>$ 과의 비교를 위해 동일한 검증조건에서 $3 \times 5$ 잔차거래량-모멘텀 포트폴리오에 대한 분석결과를 <표 $14>$ 에 제시한다. <표 $13>$ 은 $3 \times 5$ 잔차 거래량-모멘텀 포트폴리오에 대한 분석결과이다.

<표 13>의 결과에 의하면, 높은 잔차거래량 회전율을 갖는 주식집단 내에서 $\mathrm{W}-\mathrm{L}$ 무비용 포트폴리오는 과거 형성기간에 관계없이 모두 유의한 음(-)의 모멘텀 이익을 갖는다. 패자포트 폴리오는 과거 형성기간에 관계없이 유의한 양(+)의 투자성과를 갖지만, 승자포트폴리오는 유의한 투자성과를 갖지 않는다. 한편, 낮은 잔차거래량 회전율을 갖는 주식집단 내에서는 대부분의 포트폴리오가 비유의한 투자성과를 갖는다. 이러한 결과는 앞서 <표 3>에서 높은 거래량 회전율을 갖는 주식집단에서 확인된 유의한 음(-)의 모멘텀 이익이 잔차거래량 회전율을 이용한 주식집단 내에서도 동일하게 나타남을 보여준다. 또한 $\mathrm{W}-\mathrm{L}$ 무비용포트폴리오의 음(-)의 모멘텀 이익은 패자포트폴리오의 강한 성과 반전(하락 $\rightarrow$ 상승)에 의한 양(+)의 투자성과에 기인함을 보여준다.

<표 14>는 미래 보유기간을 1 개월에서 12 개월로 늘릴 때 높은 잔차거래량 회전율을 갖는 주식집단 내에서 모멘텀 전략의 투자성과의 변화를 분석한 결과이다. <표 $14>$ 에서 $\mathrm{W}-\mathrm{L}$ 무비용포트폴리오는 모두 음(-)의 투자성과를 보이고, 그 음(-)의 성과는 형성기간 12 개월의 경우는 보유기간 6 개월까지. 형성기간 6 개월의 경우는 보유기간 3 개월까지, 그리고 형성기간 3 개월의 경우는 보유기간 3 개월까지 유의하다. 패자포트폴리오는 형성기간에 관계없이 보유기간 6 개월까지 유의한 양 $(+)$ 의 투자성과를 보인다. 하지만, 승자포트폴리오는 대부분의 경우 유의성 판단 기준을 만족시키지 못한다. 이는 $\mathrm{W}-\mathrm{L}$ 무비용포트폴리오에서 관찰되는 유의한 음(-)의 모멘텀 이익이 패자포트폴리오의 성과가 반전하여 지속적으로 양(+)의 값을 가져다주는 것에 


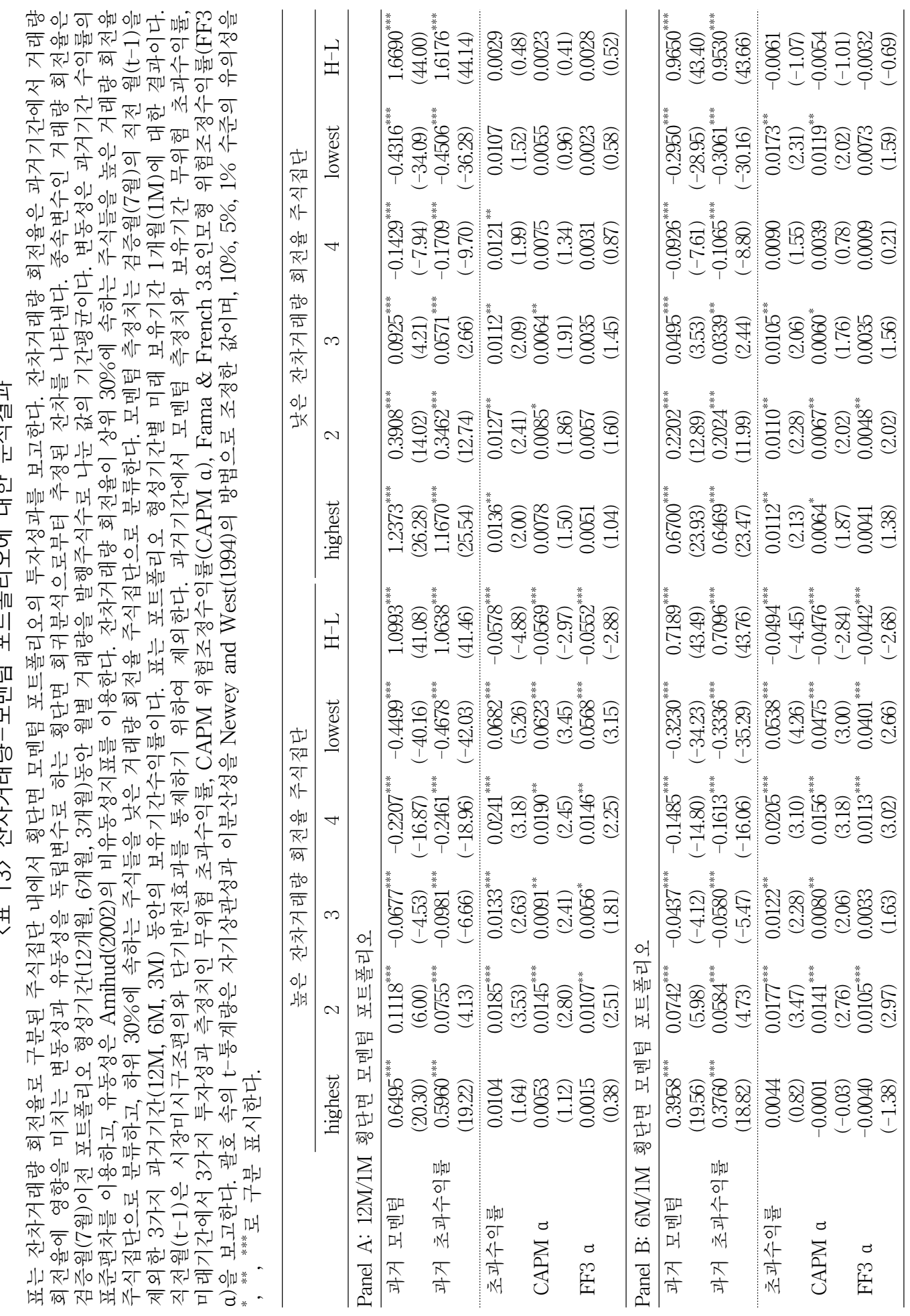




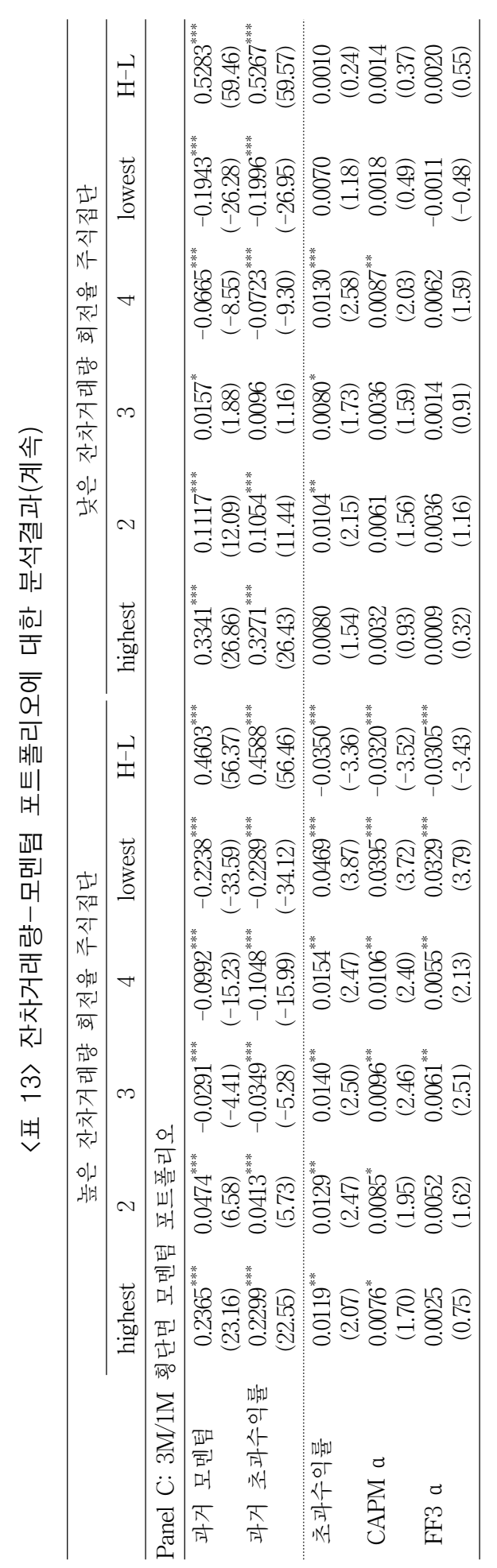




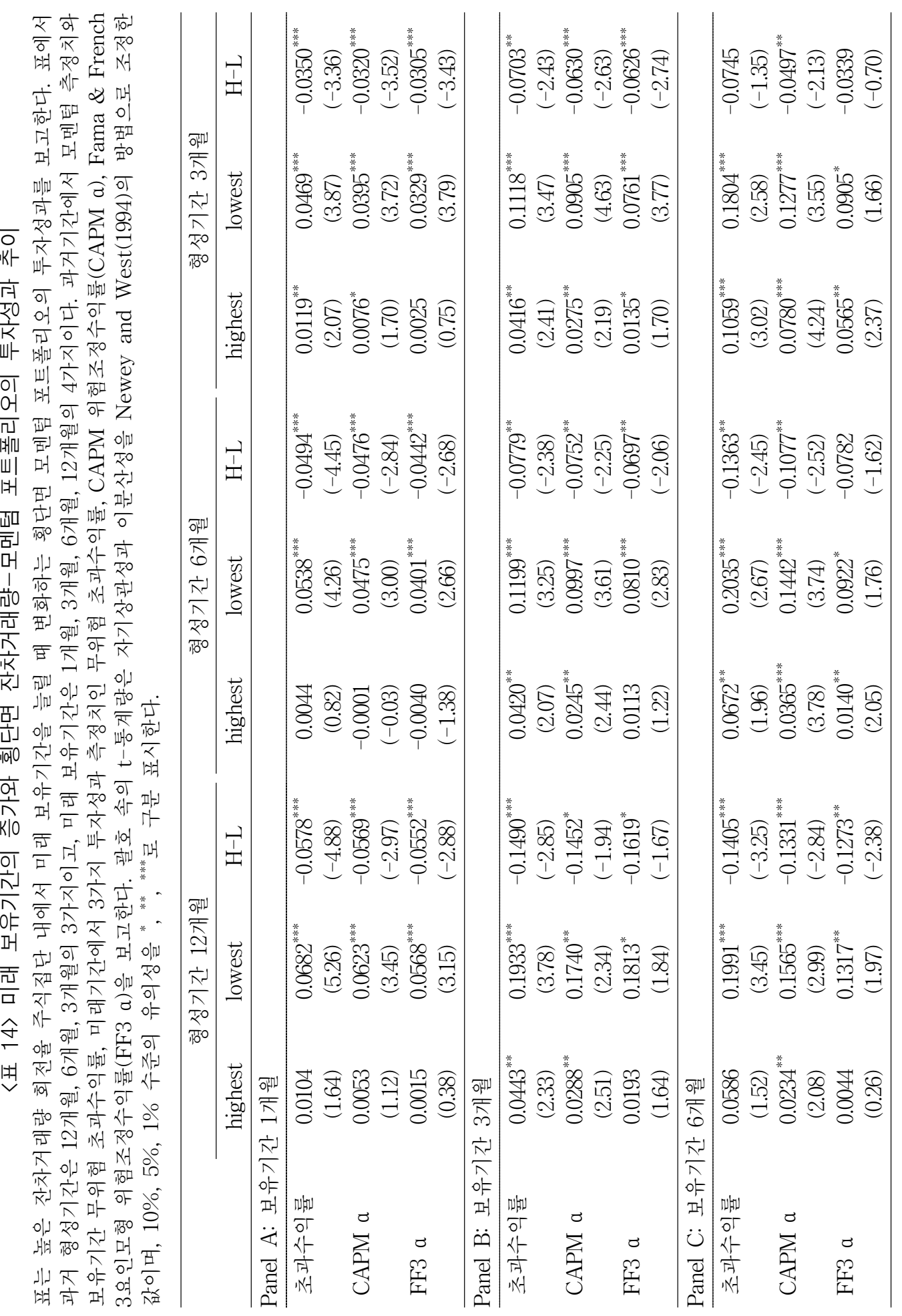


한국증권학회지 제49권 4호 (2020)

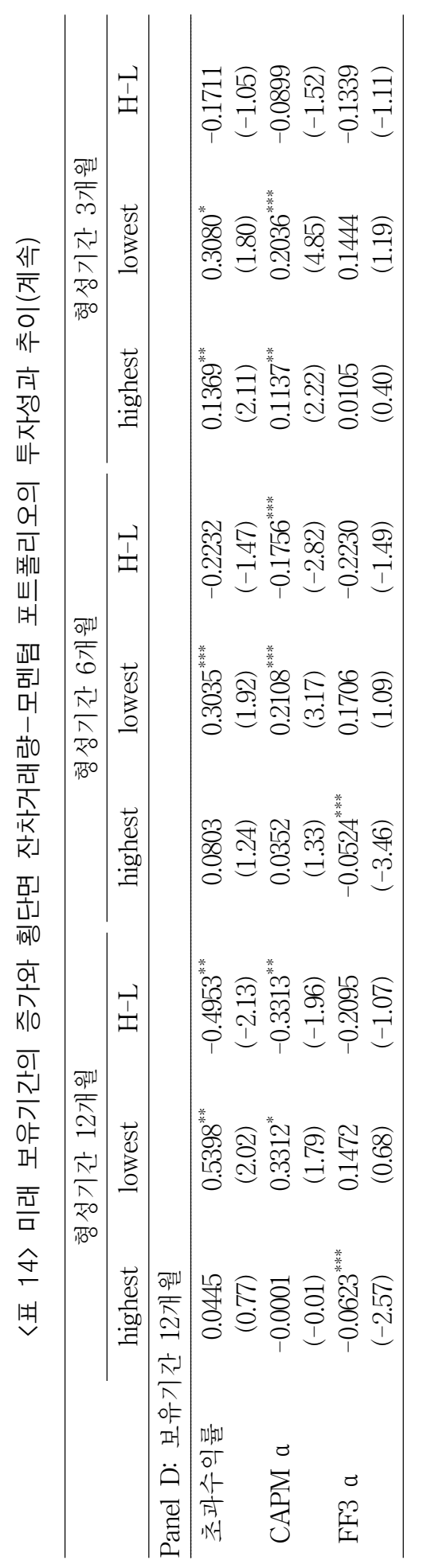


Investor Attention, Market Dynamics, and Momentum in the Korean Stock Market

강하게 의존한다는 것을 알 수 있다. 결국, <표 7>에서 확인된 결과와 잔차거래량 회전율을 이용한 주식집단 내에서 확인한 결과는 질적으로 동일하다.

\section{6. 결론 및 시사점}

본 연구는 한국 주식시장(유가증권시장과 코스닥시장)에서 거래되는 주식들을 대상으로, 외환위기와 외국인 투자자유화 조치 이후인 2000년 7월부터 2019년 6월의 표본기간 동안에 투자자관심과 주식시장 상황의 동적 특성이 모멘텀 효과에 미치는 영향을 검증하였다. 연구를 위해 선행연구와는 차별적인 내용을 실증설계에 반영하였다. 즉, 투자자관심의 대용변수인 거래량 회전율과 과거기간의 보유기간수익률로 측정되는 모멘텀 측정치를 기준으로 $3 \times 5$ 거래량-모멘텀 포트폴리오를 구성하고 다양한 모멘텀 전략의 효과를 검증한다. 이후 확인된 모멘텀 효과의 원인분석을 위해 승자/패자 포트폴리오의 투자성과의 분포 속성, 계절성 영향, 투자자의 과잉반응 정도와 매도경향의 차이에 따른 미래 투자성과의 차이, 그리고 미래 보유기간을 늘림에 따른 모멘텀 효과의 변화 패턴 등을 분석한다. 또한 과거기간과 미래기간의 주식시장 상황의 동적 특성이 모멘텀 효과에 미치는 영향을 검증한다. 분석결과의 강건성 확인을 위해 잔차모멘텀과 잔차거래량 회전율을 이용하여 동일한 검증을 수행한다.

본 연구의 주요 결과를 요약하면 다음과 같다. 첫째, 투자자의 관심이 높은 주식집단 (높은 거래량 회전율 주식집단) 내에서 유의한 음(-)의 모멘텀 이익이 확인되지만, 투자자 관심이 낮은 주식집단 (낮은 거래량 회전율 주식집단) 내에서는 유의한 결과를 확인할 수 없다. 높은 거래량 회전율 주식집단 내에서 승자포트폴리오는 미래 보유기간에서 유의하지 않은 양 $(+)$ 의 성과를 보이나 그 성과는 큰 폭으로 하락하는 모습을 보이며, 패자포트폴리오는 미래 기간에 큰 폭의 상승반전을 통해 유의한 양(+)의 성과를 실현한다. 둘째, 음(-)의 모멘텀 이익에 대한 계절성 영향은 패자포트폴리오 보다는 승자포트폴리오에서 보다 민감하게 나타나며 패자포트 폴리오에서 나타나는 성과반전 특성은 계절성에 큰 영향을 받지 않는다. 셋째, 거래량 회전율이 높은 주식집단에서 과거기간의 승자/패자 포트폴리오의 과잉반응 정도에 따른 미래 보유기간의 투자성과는 과잉반응 정도가 높은 집단이 낮은 집단에 비해 보다 강한 음(-)의 모멘텀 효과를 보여준다. 즉, 과잉반응 정도는 미래기간 모멘텀 이익에 의미 있는 영향을 미친다. 또 처분효과에 근거하여 관찰된 투자자의 매도경향은 승자포트폴리오에서 높은 값을 가지며, 패자포트폴리오 에서는 높은 손실회피경향이 나타나고 이 손실회피경향은 승자포트폴리오의 매도경향보다 높게 나타난다. 넷째, 주식시장 상황의 동적 특성을 고려한 결과는 한국 주식시장에서 관찰된 음(-)의 모멘텀 이익은 과거기간과 미래기간 시장상황의 동적 특성에 관계없이 일관되게 관찰되나, 과거기간과 미래기간의 시장상황이 반전하는 전환시장에서 승자포트폴리오의 음(-)의 투자성과와 패자포트폴리오의 양(+)의 투자성과에 기인하여 W-L 무비용포트폴리오는 유의한 음(-)의 모멘텀 이익을 강하게 보여준다. 다섯째, 잔차모멘텀과 잔차거래량 회전율을 이용한 강건성 분석 결과는 한국 주식시장에서 확인되는 음(-)의 모멘텀 이익이 주식수익률에 영향을 미치는 공통요인의 영향을 통제한 경우에도 일관되게 확인되며, 투자자관심이 높은 주식집단 에서 음(-)의 모멘텀 이익이 강하게 나타나는 현상은 개별주식의 변동성과 유동성 특성과 관계없이 나타남을 확인시켜준다. 
한국증권학회지 제49권 4호 (2020)

본 연구의 결과는 한국 주식시장에서 음(-)의 모멘텀 이익이 강건하게 확인됨을 보여준다. 이는 서구지역에서 일반적으로 보고되는 전통적인 양 $(+)$ 의 모멘텀 이익과 대비되는 결과이나, 한국 주식시장을 포함한 아시아 주식시장에서는 모멘텀 전략으로부터 양 $(+)$ 의 이익을 얻을 수 없다는 Chui et al.(2000, 2010)의 결과나 한국 주식시장에서 음(-)의 모멘텀 이익을 보고한 선행연구(Chae and Eom, 2009; Lee and Cho, 2014; Kim and Byun, 2011)와는 일관성을 갖는다.

나아가 본 연구의 결과는 음(-)의 모멘텀 이익이 승자포트폴리오 보다는 패자포트폴리오에서 확인되는 강한 성과반전에 의한 결과이며, 이러한 특성은 과거기간의 주가변동에 대한 투자자들의 과잉반응 정도가 클수록 강하게 나타남을 보여준다. 또 과거와 미래의 주식시장 상황이 전환되는 경우 음(-)의 모멘텀 이익이 강하게 나타남을 보여준다. 패자포트폴리오에서 나타나는 강한 성과반전에 따른 음(-)의 모멘텀 이익은 패자포트폴리오에서는 과잉반응이 승자포트폴리오 에서는 과소 또는 지연반응이 발생함을 의미한다.25) 이러한 현상은 투자자의 인지부조화 (cognitive dissonance)와 과신(overconfidence)으로 부분적으로 설명될 수 있다. 즉, 자신이 느끼는 인지부조화를 최소화하는 방향으로 행동하는(Festinger, 1957) 투자자는 과거기간의 승자를 매입한 경우에 인지부조화를 덜 느끼며 좋은 성과가 자신의 사적정보나 능력에 따른 것이라고 과신을 하게 된다. 이는 시장의 공개정보에 비해 자신의 주관적인 예측과 판단을 과신하게 만들며 결국 공개정보에 대한 과소반응으로 이어져 양(+)의 모멘텀 이익을 가져오게 된다. 반면에 과거기간의 패자를 매입한 경우에 투자자는 보다 큰 인지부조화를 느끼게 되며, 이는 자신의 사적 판단이나 예측에 대한 의존을 줄이고 공개정보에 대한 의존을 더욱 높여 패자포트폴리오의 가격반전을 가져와 음(-)의 모멘텀 이익을 가져올 수 있다는 것이다.

한편, 행동재무학적 모형(Barberis et al., 1998; Daniel et al., 1998; Hong and Stein, 1999)에서 투자자는 뉴스에 대해 초기 과소반응에 이은 과잉반응, 이후 가격조정에 따른 반전의 특성을 보이고 이에 따라 전통적인 모멘텀 포트폴리오는 양(+)의 중기성과(모멘텀)와 음(-)의 장기 성과를 보이게 된다. 또 Ali et al.(2017)은 과거기간의 성과가 좋았던 시기에는 투자자들이 과거 패턴의 지속을 예상하고 과거전략을 반복하나 이후의 가격반전으로 모멘텀 포트폴리오의 장기성과는 강한 음 $(-)$ 의 값을 가지나, 과거기간의 성과가 나빴던 시기에는 투자자들은 승자를 팔고 패자를 사는 전환전략을 취함으로써 모멘텀포트폴리오의 장기성과는 양 $(+)$ 의 값을 보임을 보인다고 주장한다. 이러한 결과들은 본 연구의 결과와 질적으로 차이가 있다.

본 연구에서 보인 한국주식시장에서의 음(-)의 모멘텀 이익이 과거기간 패자포트폴리오의 성과가 미래기간에 반전하는 특성에 따른 것이라는 결과는 Brown and Harlow(1988), Akbas et al.(2008)과는 일관성을 가지나, 전통적인 모멘텀 전략에 관한 연구나 행동재무학적 모형의 설명, 그리고 Ali et al.(2017) 등의 결과와는 차이가 있다. 추후 본 연구에서 확인된 패자포트 폴리오의 가격반전현상과 주식시장의 동적 특성에 따른 모멘텀 전략의 성과 원인에 대해 보다 엄밀하게 분석함으로써 관련 연구에 차별적인 공헌을 할 수 있을 것으로 기대한다.

25) Brown and Harlow(1988)은 포트폴리오 구성 후 1달 기간에 승자는 의미 있는 변화를 보여주지 못하나 패자는 큰 폭의 가격반전을 실현한다는 결과를 보고한다. Akbas et al.(2008)는 과거기간에 음(-)의 모멘텀 측정치를 가졌던 집단에서 미래기간에 가격반전이 유의하게 발생하며, 모멘텀 측정치가 $(+)$ 였던 집단에서는 같은 방향으로의 가격변화(continuation)가 일어남을 보였다. 
Investor Attention, Market Dynamics, and Momentum in the Korean Stock Market

\section{References}

Akbas, F., E. Kocatulum, and S. M. Sorescu, 2008, Mispricing Following Public News: Overreaction for Losers, Underreaction for Winners, SSRN: http://dx.doi.org/10.2139/ ssrn.1107690.

Ali, U., K. Daniel, and D. Hirshleifer, 2017, One Brief Shining Moment(um): Past Momentum Performance and Momentum Reversals, SSRN: https://dx.doi.org/10.2139/ssrn.2956493.

Amihud, Y., 2002, Illiquidity and Stock Returns: Cross-section and Time-series Effects, Journal of Financial Markets, Vol. 5, pp. 31-56.

Ang, A., J. Chen, and Y. Xing, 2006, Downside risk, Review of Financial Studies, Vol. 19 (4), pp. 1191-1239.

Asem, E., and G. Y. Tian, 2010, Market Dynamics and Momentum Profits, Journal of Financial and Quantitative Analysis, Vol. 45, pp. 1549-1562.

Barber, B., and T. Odean, 2008, All that Glitters: The Effect of Attention and News on the Buying Behavior of Individual and Institutional Investors, Review of Financial Studies, Vol. 21, pp. 785-818.

Barberis, N., N. Shleifer, and R. Vishny, 1998, A Model of Investor Sentiment, Journal of Financial Economics, Vol. 49, pp. 307-343.

Blitz, D., J. Hujj, and M. Martens, 2011, Residual Momentum, Journal of Empirical Finance, Vol. 18, pp. 506-521.

Brown, K. C., and W. V. Harlow, 1988, Market Overreaction: Magnitude and Intensity, Journal of Portfolio Management, Vol. 14, pp. 6-13.

Chae, J., and Y. Eom, 2009, Negative Momentum Profit in Korea and its Sources, Asia-Pacific Journal of Financial Studies, Vol. 38 (2), pp. 211-236.

Chaves, D. B., 2016, Idiosyncratic Momentum: U.S. and International Evidence, Journal of Investing, Vol. 25 (2), pp. 64-76.

Choe, H., R. C. Kho, and R. M. Stulz, 1999, Do Foreign Investors Destabilize Stock Market? The Korea Experience in 1997, Journal of Financial Economics, Vol. 54, pp. 227-264.

Chui, A. C. W., S. Titman, and K. C. J. Wei, 2000, Momentum, Legal Systems and Ownership Structure: An Analysis of Asian Stock Markets, SSRN: https://dx.doi.org/10.2139/ ssrn.265848.

Chui, A. C. W., S. Titman, and K. C. J. Wei, 2010, Individualism and Momentum around the World, Journal of Finance, Vol. 65 (1), pp. 6361-392.

Cooper, M. J., R. C. Gutierrez Jr. and A. Hameed, 2004, Market States and Momentum, Journal of Finance, Vol. 59, pp. 1345-1365. 
한국증권학회지 제49권 4호 (2020)

Corwin, S., and J. Coughenour, 2008, Limited Attention and the Allocation of Effort in Securities Trading, Journal of Finance, Vol. 63, pp. 3031-3067.

Daniel, K., and T. J. Moskowitz, 2016, Momentum Crashes, Journal of Financial Economics, Vol. 122, pp. 221-247.

Daniel, K., D. Hirshleifer, and A. Subrahmanyam, 1998, Investor Psychology and Security Market under- and Overreactions, Journal of Finance, Vol. 53 (6), pp. 1839-1885.

Datar, K., N. Y. Naik, and R. Radcliffe, 1998, Liquidity and Asset Returns: An Alternative Test, Journal of Financial Markets, Vol. 1, pp. 203-220.

Du, D., Z. Huang, and B. S. Liao, 2009, Why is there no Momentum in the Taiwan Stock Market? Journal of Economics and Business, Vol. 61, pp. 140-152.

Eom, C., 2012, Re-examination on Cross-section of Expected Stock Returns under Up/Down Market Conditions, Asian Review of Financial Research, Vol. 25 (4), pp. 599-639.

Eom, C., W. B. Lee, and J. W. Park, 2014, A Reexamination of the Size Effect in the Korean Stock Market, Korean Journal of Financial Management, Vol. 31 (3), pp. 113-151.

Eom, C., W. B. Lee, and J. W. Park, 2019, The Relationship between Conditional Volatility and Stock Return, and Characteristics of Stock Return Volatility: A Disaggregated Approach in the Korean Stock Market, Korean Journal of Financial Management, Vol. 36 (3), pp. 1-28.

Eom, C., W. B. Lee, R. S. Park, U. Chang, and J. W. Park, 2014, A Study on the Relationship between Idiosyncratic Volatility and Stock Returns in the Korean Stock Markets, Korean Journal of Financial Studies, Vol. 43 (4), pp. 735-784.

Eom, Y., 2013, Momentum Profits and Firm Size, Korean Journal of Financial Studies, Vol. 42 (5), pp. 901-927.

Fama, E. F., and K. R. French, 1992, The Cross-section of Expected Stock Returns, Journal of Finance, Vol. 47, pp. 427-465.

Fama, E. F., and K. R. French, 1993, Common Risk Factors in the Returns on Stocks and Bonds, Journal of Financial Economics, Vol. 33, pp. 3-56.

Festinger, L., A Theory of Cognitive Dissonance, Stanford University Press 1964 (1st ed., 1957).

Grinblatt, M., and B. Han, 2005, Prospect Theory, Mental Accounting, and Momentum, Journal of Financial Economics, Vol. 78, pp. 311-339.

Hameed, A., and Y. Kusnadi, 2002, Momentum Strategies: Evidence from Pacific Basin Stock Markets, Journal of Financial Research, Vol. 25 (3), pp. 383-397.

Hanauer, M., 2014, Is Japan Different? Evidence on Momentum and Market Dynamics, International Review of Finance, Vol. 14 (1), pp. 141-160. 
Investor Attention, Market Dynamics, and Momentum in the Korean Stock Market

Hong, H., and J. Stein, 1999, A Unified Theory of Underreaction, Momentum Trading, and Overreaction in Asset Markets, Journal of Finance, Vol. 54, pp. 2143-2184.

Hou, K., L. Peng, and W. Xiong, 2009, A Tale of Two Anomalies: The Implications of Investor Attention for Price and Earning Momentum, SSRN: https://dx.doi.org/10.2139/ssrn. 976394.

Jegadeesh, N., 1990, Evidence of Predictable Behavior of Security Returns, Journal of Finance, Vol. 45, pp. 881-898.

Jegadeesh, N., and S. Titman, 1993, Returns to buying Winners and Selling Losers: Implications for Stock Market Efficiency, Journal of Finance, Vol. 48 (1), pp. 65-91.

Kahneman, D., and A. Tversky, 1979, Prospect Theory: An Analysis of Decision under Risk, Econometrica, Vol. 47, pp. 263-291.

Kahneman, D., Attention and Effort, Prentice Hall, New Jersey, 1973.

Kang, J., K. Kown, and H. J. Park, 2014, Momentum and Foreign Investors: Evidence from the Korean Stock Market, Emerging Markets Finance \& Trade, Vol. 50 (5), pp. 131-147.

Karlsson, N., G. Loewenstein, and D. Seppi, 2009, The Ostrich Effect: Selective Attention to Information, Journal of Risk Uncertainty, Vol. 38, pp. 95-115.

Kho, B. C., 1997, Risk Premium and Profitability of Relative Strength Strategies, Korean Journal of Financial Management, Vol. 14 (1), pp. 1-21.

Kim, C. S., 2000, On the Efficiency of the KOSDAQ Market, Korean Journal of Financial Studies, Vol. 27 (1), pp. 331-361.

Kim, K., and J. Byun, 2011, Studies on Korean Capital Markets from the Perspective of Behavioral Finance, Asian Review of Financial Research, Vol. 24 (3), pp. 953-1050.

Kim, S., 2012, A Study on the Profitability of the Trading Strategies Using Past Returns, Asian Review of Financial Research, Vol. 25 (2), pp. 203-246.

Lee, C. M. C., and B. Swaminathan, 2000, Price Momentum and Trading Volume, Journal of Finance, Vol. 55 (5), pp. 2017-2069.

Lee, D., and J. Cho, 2014, Stock Price Reactions to News and the Momentum Effect in the Korean Stock Market, Asia-Pacific Journal of Financial Studies, Vol. 43, pp. 556-588.

Lin, C., K. C. Ko, Z. X. Feng, and N. T. Yang, 2016, Market Dynamics and Momentum in the Taiwan Stock Market, Pacific-Basin Finance Journal, Vol. 38, pp. 59-75.

Lo, A. W., and A. C. MacKinlay, 1990, When are Contrarian Profits Due to Stock Market Overreaction? Review of Financial Studies, Vol. 3 (2), pp. 175-205.

Newey, W. K., and K. West, 1994, Automatic Lag Selection in Covariance Matrix Estimation, Review of Economic Studies, Vol. 61, pp. 631-653. 
한국증권학회지 제49권 4호 (2020)

Park, K. I., and C. Jee, 2006, Contrarian Strategy Based on Past Stock Return and Volatility, Korean Journal of Financial Management, Vol. 23 (2), pp. 1-25.

Pashler, H., and J. Johnston, Attentional Limitations in Dual-Task Performance, In: Pashler, H., (Ed.), Attention, Psychology Press, 1998.

Sedlacek, T., Economics of Good and Evil: The Quest for Economic Meaning from Gilgamesh to Wall Street, Oxford University Press, 2011.

Shalen C. T., 1993, Volume, Volatility, and the Dispersion of Beliefs, Review of Financial Studies, Vol. 6 (2), pp. 405-434.

Shefrin, H., and M. Statman, 1985, The Disposition to Sell Winners Too Early and Ride Losers Too Long: Theory and Evidence, Journal of Finance, Vol. 40, pp. 777-790.

Statman, M., S. Thorley, and K. Vorkink, 2006, Investor Overconfidence and Trading Volume, Review of Financial Studies, Vol. 19 (4), pp. 1531-1565. 